\title{
REVIEW OF POTENTIAL HOST ROCKS FOR RADIOACTIVE WASTE DISPOSAL IN THE SOUTHEAST UNITED STATES - SOUTHERN PIEDMONT SUBREGION
}

\section{ACRES AMERICAN INCORPORATED}

Buffalo, New York

TIS FILE

RECORD COPY

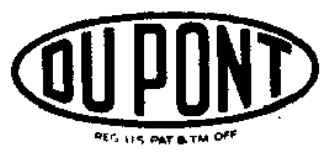

E. I. du Pont de Nemours \& Co. Savannah River Laboratory

Aiken, SC 29808 
This report was prepered by E. I. du Pont de Nemours and Company (Du Pont) for the United States Department of Energy under Contract DE-ACO9-76SR00001 and is an account of work performed under that Contract. Neither the United Stetes, the United States Department of Energy nor Du Pont, nor any of their employees, makes any warranty, express or implied, or assumes any legal liability or respansibility for the sccuracy, completeness, or wectulness of any informetion, apporatus, product, or process disclosed herein, or represents that its use will not infringe privately owned rights. Aeference herein to any spectfic commerical product, process, or service by trade name, mark, manufacturer, or otherwise does not necesarily constitute or imply endorsement, recommendation, or favoring of same by Du Pont or by the United States Government or any agency thereof. The views and opinions of authors expressed herein do not necessarily state or reflect those of the United States Government or any agoncy thereof.

Printed in the United Stetes of Americe

Available from

National Technical Information Service

U. S. Depertment of Commerce

5285 Port Royal Rosd

Springfietd, Virgini 22161

Price: Printed Copy A07; Microfiche A01 
DP-1567

UC-70

\section{REVIEW OF POTENTIAL HOST ROCKS FOR RADIOACTIVE WASTE DISPOSAL IN THE SOUTHEAST UNITED STATES - SOUTHERN PIEDMONT SUBREGION}

ACRES AMERICAN INCORPORATED

Buffalo, New York

Work Completed June 1978

Report Issued October 1980

Issued by E. I. du Pont de Nemours \& Co. Savannah River Laboratory Aiken, SC 29808 


\section{ABSTRACT}

A literature study was conducted on the geology of the Southern Piedmont province in the states of Maryland, Virginia, North Carolina, South Carolina, and Georgia. The purpose was to ident ify geologic areas potentially suitable for containment of a repository for the long-term isolation of solidified radioactive waste. The crystalline rocks of the Southern Piedmont province range in age from Precambrian to Paleozoic, and are predominantly slates, phyllites, argillites, schists, metavolcanics, gneisses, gabbros, and granites. These rock units were classified as either "favorable," "potentially favorable," or "unfavorable" as potential study areas based on an evaluation of the geologic, hydrologic, and geotechnical characteristics. No socio-economic factors were considered. Rocks subjected to multiple periods of deformation and metamorphism, or described as highly fractured, or of limited areal extent were generally ranked as unfavorable. Potentially favorable rocks are primarily the high-grade metamorphic gneisses and granites. Sixteen areas were classified as being favorable for additional study. These areas are primarily large igneous granite plutons as follows: the Petersburg granite in Virginia; the Rolesville-Castallia, Churchland, and Landis plutons in North Carolina; the Liberty Hi11, Winnsboro, and Ogden plutons in South Carolina; and the Siloam, Elberton, and six unnamed granite plutons in Georgia. 
DP-1567

\section{PREFACE}

The disposal of radioactive waste in the proper geologic environment offers a high potential for isolating the waste from man's environment for the period of time required for the waste to decay to innocuous levels. As part of the National Waste Terminal Storage Program, the Savannah River Laboratory has responsibility for studies related to the storage of waste in the geologic environment in the Southeast. For the purposes of this study, the Southeast consists of the igneous and metamorphic rocks of the Piedmont, the sands and clays of the Coastal Plain, and the mudstones and shales of the Triassic basins from Maryland to Georgia. To implement these studies, a literature review of each of these three geologic provinces was performed by subcontract. The purpose of these reviews was to designate areas that, from a geotechnical point of view, offer a potential for field exploration to investigate their charcteristics and suitability for disposal of solidified high-level radioactive waste. This report covers the Southern Piedmont subregion and was prepared by Acres American, Inc, of Buffalo, New York. Because of the geologic complexity of the Piedmont and its generally high potential for waste storage, the general study reported herein was complemented by four detailed studies of literature and existing knowledge by experts in the local geology. These reports are on the piedmont of Virginia and Maryland (DP-1561), North Carolina (DP-1562), South Carolina (DP-1563), and Georgia (DP-1564). From all of these supporting studies, the Savannah River Laboratory prepared a summary report (DP-1559) which designates the areas favorable for field exploration.

This report is a general study of the Southern Piedmont by Acres American, Inc. The study is being published by the Savannah River Laboratory to make it generally available. However, the conclusions reached are those of Acres American, and they are responsible for its content.

I. W. Marine Savannah River Laboratory

October 7,1980 


\section{TABLE OF CONTENTS}

LIST OF TABLES

LIST OF PLATES

Page

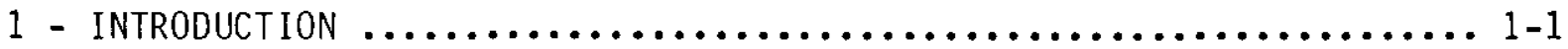

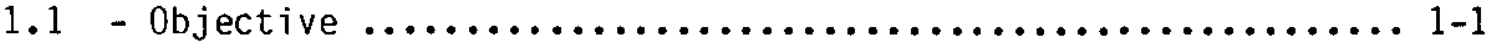

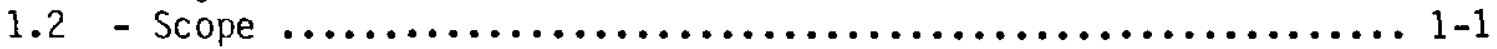

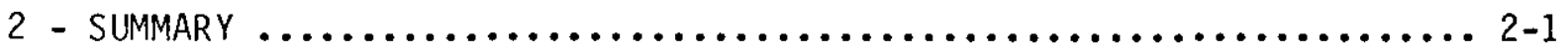

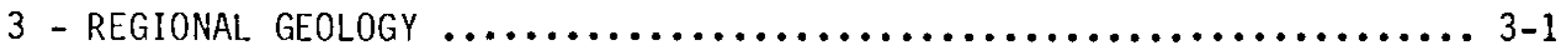

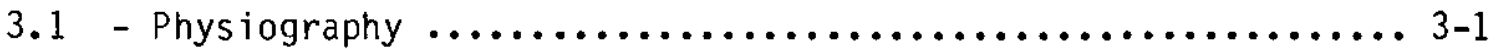

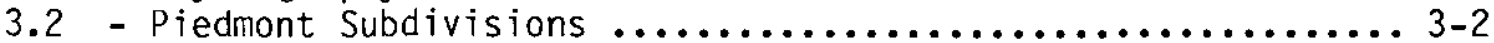

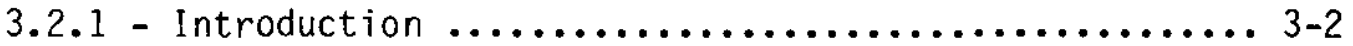

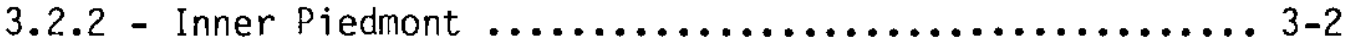

3.2 .3 - Kings Mountain Belt ........................... 3-2

3.2 .4 - Charlotte Belt ............................... 3-2

3.2 .5 - Carolina Slate Belt ............................ 3-4

3.3 - Tectonic History ............................. $3-4$

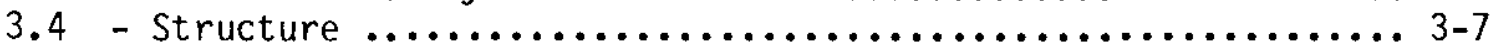

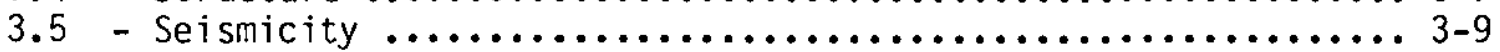

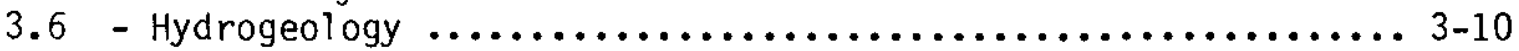

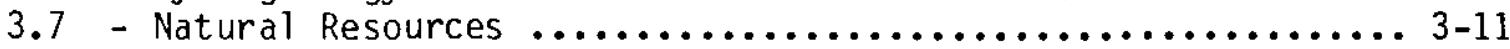

4 - CRITERION FOR SELECTING POTENTIAL GEOLOGIC FIELD STUDY AREAS ..... 4-1

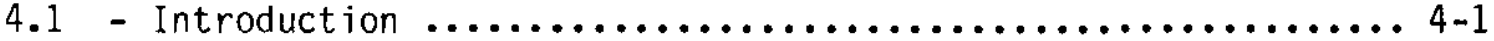

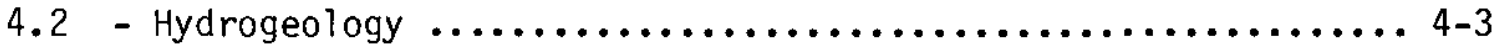

4.3 - Geotechnical ................................... 4-4

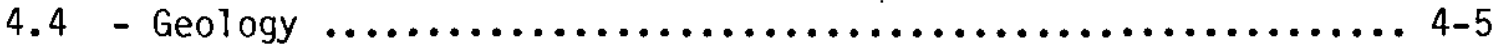

5 - REVIEW OF POTENTIAL GEOLOGIC FIELD STUDY AREAS $\ldots \ldots \ldots \ldots \ldots \ldots \ldots \ldots$

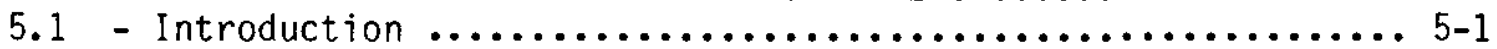

5.2 - Criteria Application ............................. 5-1

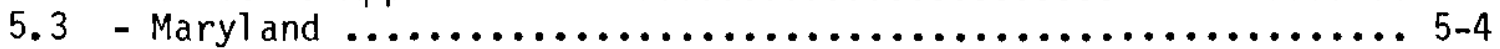

5.3 .1 - General Geology ............................. 5-4

5.3 .2 - Potential Field Study Areas ................. 5-5

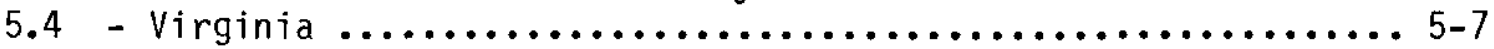

5.4 .1 - General Geology ........................... 5-7

5.4 .2 - Potential Field Study Area ................... 5-8

5.5 - North Carolina ................................ 5-10

5.5 .1 - General Geology ............................ 5-10

5.5 .2 - Potential Field Study Areas ................... 5-12

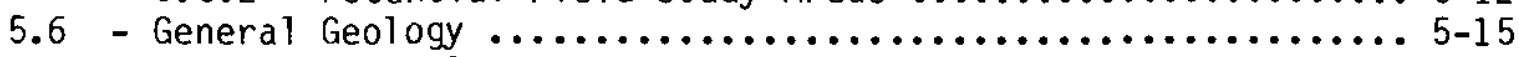

5.6 .1 - General Geology ........................... 5-15

5.6 .2 - Potential Field Study Areas ................... 5-17

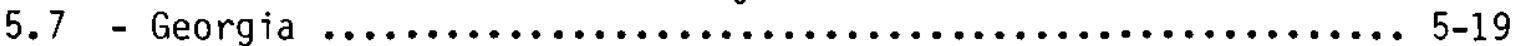

5.7 .1 - General Geology ........................... 5-19

5.7 .2 - Potential Field Study Areas .................. 5-21 


\section{LIST OF TABLES}

Number

1

Title

Modified Mercalli (MM) Earthquake Intensity Scale

Earthquake Intensities of $V$ and Greater-Southeast U.S.

Physical and Mechanical Rock Properties

Geological Review of Rock Units - Maryland Piedmont Province Geological Review of Rock Units - Virginia Piedmont Province Geological Review of Rock Units - North Carolina Piedmont Province

Geological Review of Rock Units - South Carolina Piedmont Province

Geological Review of Rock Units - Georgia Piedmont Province 


\begin{tabular}{|c|c|}
\hline Number & Title \\
\hline 1 & Physiographic Map \\
\hline 2 & Southern Piedmont Subdivisions \\
\hline 3 & Tectonic Map of Southern Piedmont \\
\hline 4 & Cross Section - Southern Piedmont \\
\hline 5 & Southeast United States Earthquake Epicenter Map \\
\hline 6 & $\begin{array}{l}\text { Maryland Piedmont Province - Potential Geologic Field } \\
\text { Study Areas }\end{array}$ \\
\hline 7 & $\begin{array}{l}\text { Virginia Piedmont Province - Potential Geologic Field } \\
\text { Study Areas }\end{array}$ \\
\hline 8 & $\begin{array}{l}\text { North Carolina Piedmont Province - Potential Geologic Field } \\
\text { Study Areas }\end{array}$ \\
\hline 9 & $\begin{array}{l}\text { South Carolina Piedmont Province - Potential Geologic Field } \\
\text { Study Areas }\end{array}$ \\
\hline 10 & $\begin{array}{l}\text { Georgia Piedmont Province - Potential Geologic Field Study } \\
\text { Areas }\end{array}$ \\
\hline
\end{tabular}


$\underline{1 \text { - INTRODUCTION }}$

\section{1 - $\underline{\text { Objective }}$}

This report presents the results of a geotechnical investigation undertaken by Acres American Incorporated, Buffalo, New York, to identify geologic formations within the crystalline rocks of the southern Piedmont for subsequent study to determine their suitability for storage of radioactive waste.

The work was performed for E. I. DuPont de Nemours \& Company, Savannah River Laboratory, Aiken, South Carolina under contract order number AX450039L.

\section{$1.2-\underline{\text { Scope }}$}

The subregion studied included the southern Piedmont province (as defined by physiography and structure) which falls within the States of Maryland, Virginia, North Carolina, South Carolina and Georgia, an area of over $116,000 \mathrm{sq} . \mathrm{km}$. $(45,000$ square miles $)$. The subregion is bordered on the east by the Fall Line, which is defined by the contact between the Piedmont rocks and the unconsolidated Cretaceous and Tertiary (140-2 million years ago) sediments of the Coastal Plain, and on the west by the Blue Ridge, a complex series of Precambrian (>600 million years ago) and Cambrian (600-500 million years ago) age rocks. The Triassic age (230-180 million years) basins which transect the crystalline Piedmont rocks were excluded from the scope of this study, but are covered by a parallel study by others.

The scope for this study was set out by Savannah River Laboratory in their Request for Proposal dated September 21, 1977, which is reproduced in Appendix A.

The geology within the subregion was reviewed to identify potential host rocks that may be favorable for exploration for the long-term storage of radioactive wastes. The study was based solely on overall geologic, 
geotechnical, and geohydrologic suitability of the rock. No consideration was given to socioeconomic or nontechnical restraints. Such areas were considered political, and thus not within the scope of this study.

The methods employed by Acres in defining rock suitability included:

(a) a literature survey of published and unpublished material,

(b) discussions with State and Federal Geologic Surveys and other persons knowledgeable of the study area.

No field work was undertaken for this study.

The ultimate intent of this study was to identify candidate study areas and to compile background information in the form of a bibliography on these areas that could be utilized in further studies to more closely define and locate suitable localities for field studies for the disposal of radioactive wastes. 
2 - SUMMARY

This study identified potential host rocks within the southern Piedmont in the States of Maryland, Virginia, North Carolina, South Carolina, and Georgia that may be favorable for further investigation for underground disposal of radioactive waste material. The study entailed:

- a review of the regional geology, hydrogeology, seismicity, and natural resources

- establishment of a criteria for defining "potentially favorable" and "favorable" host rocks, and

- a review and categorization of all the individual rock units within the subregion for their overall suitability.

The crystalline Piedmont rocks range in age from Precambrian (>600 million years ago) to middle-late Paleozoic (400-230 million years ago), and are predominantly slates, phyllites, argillites, schists, metavolcanics, gneisses, and granites. The southern Piedmont has experienced multiple periods of regional metamorphism, hard rock deformation, and igenous intrusive activity during the Paleozoic and Mesozoic era (600-60 million years ago). The Piedmont is, therefore, a complex and diversified assemblage of rock units.

The criterion developed for this study identified potential host rocks within the southern Piedmont that may be considered for further investigation for underground disposal of radioactive waste. The criterion was based wholly on the rocks' hydrogeologic, geotechnical and geologic acceptability with no consideration given to socioeconomic or nontechnical factors.

These three technical criteria were subdivided into those properties and conditions that were considered the most crucial in assuring the long-term stability and containment of radioactive waste material. These included: 
Hydrogeology: Permeability

Hydraulic Gradient

Geotechnical:

Physical and Mechanical Properties

Unconf ined Compressive Strength

Modulus of Elasticity

Rock Quality

Joint Spacing

In-situ Stress

Geology: Unit Dimension

Structural Complexity

Lithology

The rocks within the subregion of study were classified by origin as:

Igneous

Met amorphic

Volcanic and Metavolcanic

Sedimentary

Each individual rock unit was tabulated; described by age, type, and petrologic description (where available); and classified as being either "acceptable", "marginally acceptable" or "unacceptable" for each of the individual properties and/or condition listed above. These classifications were assigned by the Acres geologist based on a review of the geologic literature and discussions with the various state geologists.

The overall favorability of the unit was then determined based on an evaluation of the classifications of the rock's properties and/or conditions. The rock units were classified as either "favorable", "potentially favorable" or "unfavorable", as potential "study areas". Only those rocks that appeared as the most suitable were given the "favorable" ranking. 
Because of the large area of study and its diversified geology, it was impossible to collect and review all the available geologic literature pertaining to the Piedmont rocks. Consequently, additional data and studies could change the classification of several of these rock units.

A total of sixteen areas were classified as being the most "favorable" for additional study. These units, ranging from Virginia to Georgia, were primarily the large, younger syn-or post-metamorphic, igneous granitic plutons. These rocks appeared to demonstrate the most suitable geotechnical, hydrogeologic, and geologic properites and conditions for housing a radioactive waste repository. Additional studies, however, will be required within these chosen rock bodies to accurately define their extent, chemical, physical, and thermal properties, as well as the deep hydrologic regime before the final suitability of the rock can be determined.

A total of 23 rock types or units were classified as being "potentially favorable". These rocks, which were primarily the high-grade metamorphic gneisses and granites, cover a large portion of the southern Piedmont. As defined within the criteria, these rocks would require extensive study to locate a suitable rock mass within these rocks for housing a radioactive waste repository. 
3 - REGIONAL GEOLOGY

\section{1 - Physiography}

The Piedmont physiographic province is a broad upland of moderate altitude with several lowlands scattered through the region, bordered on the west by the Blue Ridge Province* and overlapped on the east by the sediments of the Coastal Plain (see Plate 1). The province trends in a northeasterly direction extending $1350 \mathrm{~km}$ ( 840 miles) from Alabama to Central New Jersey, varying in width from $60 \mathrm{~km}$ (40 miles) in northern Virginia to nearly $240 \mathrm{~km}$ (150 miles) in the Carolinas.

Regional slopes in the Piedmont Province are generally eastward. General altitude increase from north to south ranging from $90-120 \mathrm{~m}$ (300 to 400 feet) in Maryland to $550 \mathrm{~m}$ (1800 feet) in Georgia. The eastern boundary between the Piedmont Province and the Coastal Plain is commonly referred to as the Fall Line. This line marks the contract between the resistant rocks of the Piedmont and the unconsolidated Cretaceous and Tertiary sediments of the Coastal Plain.

Many portions of the Piedmont are covered by a deep saprolite soil which in places is as much as $30 \mathrm{~m}$ (100 feet) thick. This thick saprolite is evidence that the Piedmont has been exposed to extensive long-term weathering. The gently rolling terrain of the Piedmont has given the appearance of being a peneplain. The lack of structural or lithologic control of drainage is common throughout the province. Generally streams tend to cross-cut the regional structure, flowing from west to east and southeast towards the Atlantic Ocean. Numerous monadnocks are present along the province's western boundary.

\footnotetext{
*The boundary between the BTue Ridge and the Piedmont has been placed by some geologists at the Brevard Fault Zone (Reed \& Bryant, 1964; Hatcher, 1971a) while others consider the rocks west of the Brevard in Georgia and Alabama as part of the Piedmont (Crawford and Medlin, 1970). This study has, considered the Brevard Zone as marking the western boundary of the Piedmont Province.
} 
The Piedmont rocks are deformed and metamorphosed rocks of late Precambrian to late Paleozoic age (650-230 million years ago), which overlie older Precambrian (>650 million years ago) basement gneisses (see Section 3.3). Several Triassic, sedimentary basins occur in a general northeast-southwest direction within the province. These Triassic basins were formed by a downfaulting, with the boundary faults generally following the structural trends in the older rocks.

Numerous diabase dikes intrude many of the earlier Piedmont rocks.

\section{2 - Piedmont Subdivisions}

\section{2 .1 - Introduction}

The rocks of the Piedmont have been subdivided in several northeast trending belts that follow the regional structural features. These belts have been defined on the basis of similar topography, structure, rock type and metamorphic grade. Boundaries between belts are generally gradational in nature. The stratigraphic relationship of the belts suggest that they represent zones of different grades of regional metamorphism and rock composition.

The most common subdivision of the Piedmont (King, P.B., 1955) has been into the Inner Piedmont Belt, Kings Mountain Belt, the Charlotte Belt and the Carolina Slate Belt. These belts are discussed in detail in the following sections, and their locations are shown on Plate 2.

\subsection{2 - Inner Piedmont}

The Inner Piedmont comprises the widest belt within the Piedmont. It is bounded by the Kings Mountain Belt on the east, and the Brevard Fault Zone to the west. 
The belt is composed of two general rock types (Hatcher, 1972); (1) a belt of low-to-medium grade metasedimentary and metavolcanics which lies immediately southwest of the Brevard Zone and narrows southward into Georgia and Alabama and consists of graphitic phyllite, chloritemuscovite phyllite, impure marble, and quartz feldspathic augen to quartzite Henderson Gneiss, and, (2) the more abundant and extensively deformed and metamorphosed granitic gneisses, amphibolite-hornblende gneiss, biotite gneisses, schists and metagraywackes.

\subsection{3 - Kings Mountain Belt}

The Kings Mountain Be1t (Plate 2) lies in the central part of the Piedmont in South Carolina and south-central North Carolina.

The belt is largely comprised of metamorphic rocks that range from siliceous and calcareous metasediments to feldspathic, micaceous, and hornblende schists and gneiss of uncertain origin. The belt has three basic types of intrusive igneous rocks: quartz monzonite granites, biotitic granites and diabase.

The metamorphic rocks of this belt are of medium-to-low grade. The belt probably extends across both North and South Carolina, but its continuity is obscured by major intrusive bodies and metamorphic alteration.

\subsection{4 - Charlotte Belt}

The Charlotte Belt comprises a broad central part of the Piedmont. The belt 1 ies between the Carolina S1ate Belt to the southeast and the Kings Mountain Belt to the northwest (King, 1955). This belt contains more granite than other belts, and granitoid textures are common in intrusive plutons. The granitoid rocks are highly foliated with apparent remnants of bedding of the original sedimentary and volcanic rocks. The granitoid paragneiss is commonly a fine-grained, epidotebearing gneiss and migmatite of the albite-epidote amphibolite facies (Overstreet, 1970). Locally the grade of regional metamorphism rises 
to the staurolite-kyanite subfacies and, adjacent to parts of large plutons, the grade rises to the sillimanite-almandine subfacies. Three episodes of intrusive activity are evident in the Charlotte Belt (see Section 3.3). These younger intrusive rocks consist of gabbro, diorite and syenite (Butler, 1966).

In summary, the Charlotte Belt is a zone of moderate to high metamorphic grade between two belts of lower grade rocks.

\section{2 .5 - Carolina Slate Belt}

The Carolina Slate Belt is a lower rank assemblage of metasedimentary and metavolcanic rocks, including metagraywacke, tuffaceous argillites, quartzite, and metasiltstone (Hatcher, 1972).

The belt extends for more than $650 \mathrm{~km}$ (400 miles) from Virginia southwestward to central Georgia. The age of these rocks are unknown but are generally considered to be of early Paleozoic age (550 million years ago). The belt is bounded on the west by medium-grade, metamorphic rocks of the Charlotte Belt and to the east by the unconsolidated Cretaceous and Tertiary sediments of the Coastal Plain. Rocks of the Slate Belt compose much of the eastern Piedmont and crop out in large regions of Virginia, North Carolina and South Carolina. The belt has been intruded by granitic rocks of Paleozoic age. These intrusive masses are generally circular to oval in plan and are conspicuous features of both the Carolina Slate Belt and the Charlotte Belt. They were probably emplaced during middle to late Paleozoic time (see Section 3.3).

\section{3 - Tectonic History}

The tectonic history of the southern Piedmont has been complicated by multiple periods of deformation, metamorphism, and intrusion. 
The rocks have been metamorphosed at least twice since the late Precambrian (650 million years ago) (Reed and Bryant, 1964). The earliest and most severe orogenic activities to affect the southern Piedmont commenced during the early Paleozoic (500-650 million years ago) (Hatcher, 1972) causing extensive regional metamorphism and isoclinal folding. The metamorphic intensity of this event was greatest in the Inner Piedmont and the Charlotte Belts where the rocks reached the sillimanite grade and were extensively remobilized.

The last regional metamorphic event affecting the southern Piedmont probably occurred between 420 and 380 million years ago (Hatcher, 1972). The metamorphic intensity of this event was less than the earlier event, causing predominantly retrogression (Hatcher, 1972). Accompanying the metamorphism was large-scale overthrusting and folding. It was during this phase that the major fault systems to include the Brevard Zone, Towaliga, Goat Rock and Gold Hill faults were probably formed (Hatcher, 1972) (see Section 3.4). The mapped series of large plunging anticlinoria and synclinoria that trend across the southern piedmont in a general northeast-southwest direction probably are an overprint of this last major compressive event.

Igneous activity within the southern Piedmont occurred over a wide time period with the earliest being about 1 billion years ago (Ranking, et al, 1969). Paleozoic (230-650 million years ago) intrusive activity occurred pre-, syn-, and post-regional metamorphism. Based on age dating of plutons throughout the southern Piedmont, Fullagar (1971a) concluded all of the plutonic activity occurred between 595 and 300 million years ago, and that the activity could be divided into three episodes: 595 to 520 million years ago, 415 to 385 million years ago, and 300 million years ago. The oldest and youngest plutons are in the southeast portion of the Piedmont with the oldest plutons found in the charlotte Belt. To the west of the Blue Ridge there was folding between 230 and 300 million years ago, but this apparently was not accompanied by intrusive activity in the Piedmont.

The last major tectonic event affecting the southern Piedmont was a shift from a compressive to a tensional stress regime during the Permian to Triassic (280-190 million years ago) (Jurassic?) period. This tensional 
regime caused large scale normal faulted Triassic basins. These basins subsequently were filled with terrigenous sediments. Associated with this last major tectonic event was the intrusion of diabase dikes and sills that are common throughout the Piedmont.

Geologists now attribute plate tectonics as the primary mechanism for the tectonic evolution of the southern Piedmont. Although the interpretation of the model is controversial, the plate tectonic concept provides the most plausible mechanism for the generation of orogenic belts.

One of the more recent tectonic models for the evolution of the southern Piedmont is that presented by Hatcher (1972). Hatcher identified four distinct phases of developmental history of the southern Piedmont. Phase I, being the earliest phase of post-Grenville time, involved the erosion of the previously formed Grenville Mountains and deposition of the erosion products in several interconnected basins along the continental margin. Further east (seaward) there was sea-floor volcanic activity, and perhaps the development of an island arc-trench subduction zone system. Deposition began in late Precambrian on the previously deformed and intruded Grenville basement. Up to $12,800 \mathrm{~m}(42,000$ feet $)$ of sediments were deposited in some basin areas. All the sediments were poorly sorted, such as those found in the Carolina slate Belt. With the diminishing of the source area to the west the sediment changed to cleaner and better sorted. The westward clastic source ceased for a short period during the early Cambrian (650 million years ago) but reappeared and persisted as a low-relief source of fine clastics through the late Cambrian (500 million years ago) time.

The eastern Piedmont probably was a series of volcanic islands that persisted well into the Paleozoic. Phase Il, commencing in the middle Ordovician (470 million years ago), marked the first major period of regional metamorphism. Hatcher attributed this early Paleozoic folding and metamorphism to a westward-moving lithospheric plate being consumed in a subduction zone located to the east of the Carolina Slate Belt. The heat generated in the subduction zone caused widespread metamorphism and granitization in the hottest portions of the zone (Inner Piedmont). Compressive stresses exerted by the plates produced the isoclinal and recumbent folding. This phase was accompanied by synkineatic pluton intrusions. 
Phase III marked the second period of large-scale compression, low-grade metamorphism, major faulting and some intrusive activity. Hatcher relates this event to the collision of the southeastern North America plate and the Africa plate. The culmination of the collision probably produced large scale over-thrusting of the Blue Ridge and folding and faulting throughout the southern Piedmont.

Phase 4 was the last major period of tectonism in the southern Piedmont. The tensional stress regime formed during this period was caused by the decoupling and spreading of the continents to their present day position.

\section{4 - Structure}

As stated in Section 3.3, the structure of the Piedmont has been complicated by multiple periods of deformation and metamorphism which have obliterated many of the older pre-metamorphic structural features.

Plates 3 and 4 are a regional tectonic map of the Piedmont and a generalized cross section. Generally the rocks of the Piedmont are mapped as a series of large anticlinoria and synclinoria which trend in a northwest-southeast direction. Localized folding ranges from broad and open to tightly compressed, symmetric to assymetric, upright to overturned. Cleavage within the Piedmont crystalline rocks ranges from closely spaced slaty cleavage to non-existent in the more massive units.

The large faults that have been mapped in southern Piedmont, and are shown on Plate 3 , are generally considered to be post-metamorphic and post-folding in age (Hatcher, 1972). The major mapped pre-Triassic (230 million years ago) faults of the southern Piedmont are the Brevard Zone, Towaliga, Goat Rock, Gold Hill Faults as well as a series of recently mapped faults along the eastern Piedmont. Several of the larger Triassic faults are also shown on Plate 3. These faults which predominately form the boundary of the Triassic basins are outside the scope of this study, and have not been included in this discussion. 
The largest and most pronounced structure within the southern Piedmont is the Brevard Fault Zone which forms the boundary between the Blue Ridge and the piedmont. The known length of the zone is more than $520 \mathrm{~km}$ (325 miles) and its width is generally less than $5 \mathrm{~km}$ ( 3 miles). The fault is remarkably straight and independent of the structures of the Blue Ridge and Piedmont. The zone is readily distinguished on Landsat imagery (N.J. Trask, et al, 1977) and gravity maps. The zone has had a long and complicated history. Mapping across the zone shows gross contrasts on opposite sides in structural patterns and rock composition. The age and origin of the Brevard is unknown. Reed, et al (1970) postulate that movement of the Brevard started as early as the early Paleozoic (570 million years ago) and continued through the middle Paleozoic (400 million years ago) after the climax of regional metamorphism. Some authors have argued that the zone has experienced northwestward thrust faulting, others have favored strike-slip faulting, while still others have argued a combination of both movements (Hatcher, 1971a; Reed and Bryant, 1964.; Reed, Bryant and Myers, 1970). The zone was active as a shear zone as long as 346 million years ago (Odom and Fullagar, 1973). Several undisturbed Mesozoic (230-65 million years ago) age dikes which cross cut the structure, indicate that the zone (at least in part) had ceased to be active by that time.

The Towaliga and Goat Rock Faults form the northwest and southeast sides of the Kings Mountain Belt. Clarke (1952) suggested that the Towaliga, Goat Rock and Brevard may be the surface traces of a single folded fault. Later work by Bentley and Neathery (1970) show some support for this hypothesis based on aeromagnetic data. Recent aeromagnetic and aeroradioactivity maps (Bentley, et al, 1974a, 1974b) show that these faults extend northeast across Georgia and possibly into South Carolina (Howel1, 1976). They continue southwestward beneath the Coastal Plain of Alabama.

The Gold Hill Fault is a zone of shearing and cataclasis along the Charlotte-Carolina Slate Belt, from near the North Carolina-South Carolina border northeastward for approximately $135 \mathrm{~km}$ (80 miles). Sundelius (1970) shows it to be sharply discordant, dipping steeply and cutting across the layering and structure of the Slate Belt rocks on the southeast. 
Recent geologic mapping, interpretation, and field checking of aeromagnetic data by Hatcher, et al, (1977), has led them to suggest the existence of a series of closely associated faults and splays extending from $\mathrm{Alabama}$ to Virginia along the eastern Piedmont. Based heavily on interpretation of magnetic data, these authors postualte an extensive eastern Piedmont fault system which extends northeastward from the Goat Rock Fault, passing beneath segments of the Coastal Plain in the Carolinas, and continuing into Virginia. Hatcher, et al, (1977) places the movement history of these faults to be similar to that of the Brevard Fault (see Plate 3).

Within the crystalline rocks of the Piedmont are a series of unmetamorphosed Triassic rocks which are found in a series of downfaulted basins. These basins are bounded on one or both sides by large normal faults which closely follow structural trenches in the older crystalline rock.

None of the mapped faults in the southern Piedmont are believed to be active. There is no known seismic activity associated with any mapped structural features within this part of the Piedmont.

\section{$3.5-\underline{\text { Seismicity }}$}

Seismic events in the southeastern U.S. are geographically randomly scattered with the exception of several areas of clustered earthquake epicenters. The establishment of the world-wide seismograph network in the early 1960's has made it possible to more accurately define earthquake epicenter locations and magnitude. Historical records of earthquakes in the southeast date back 300 years to the earliest colonial settlement and the location of most earthquakes have been based on published and unpublished records of felt effects. Many of the early recordings are highly subjective, depending on an individual's sensitivity and activity at the time of the earthquake. Prior to 1850, much of the southeast was sparsely populated and earthquake occurrences tended to be biased around the few centers of population. Thus, many of the early earthquake epicenters may possibly have been located tens of miles from their actual point of occurrence. Due to the absence of seismography records, there is a general lack of information concerning earthquake ground motions and durations. 
The method that has been most frequently used in classifying earthquakes, and the one used in this report, has been the Modified Mercalli (MM) Intensity scale given in Table 1. This is a scale of I to XII which measures the earthquakes' effect on people, man-made structures and on the earth's surface. The measure of intensity depends on many factors which include a structure's design, foundation conditions, and the type and quality of construction, as well as the objectivity of human observation.

A plot of earthquakes of intensity $V$ or greater for the southeast is shown in Plate 5 while a list of the earthquake events with their location, intensity and magnitude (where available) is given in Table 2.

A review of the epicenter map shows several apparent "clusters" of earthquakes in the southeast. These are in the vicinity of Giles county, Virginia, along the Tennessee-North Carolina border area, and at Charleston, South Carolina. It is worth noting that none of these areas fall within the Piedmont. The largest earthquake ever recorded in the southeast U.S. the Charleston Earthquake of August 31, 1886, which had an estimated epicenter intensity of $X$ (MM).

The Piedmont generally falls within Seismic Zone 2 (Uniform Building Code), indicating an area that may be subject to moderate damage and corresponding to intensity VII (MM). As a whole, the Piedmont is considered to have low to moderate seismicity. There are no known active faults within the Piedmont and no earthquakes are known to be associated with any mapped structural or tectonic features.

\section{$3.6-$ Hydrogeology}

The Piedmont rocks have all been subjected to varying degrees of metamorphism (see Section 3.3) which has resulted in recrystallization and interlocking of mineral grain boundaries which, for all practical purposes, has eliminated water access between grain boundaries. As a result, water movement within the Piedmont rocks is essentially restricted to connected open fractures, shear zones and joints (Herrick and LeGrand, 1949). 
Unfortunately, there is little available data on groundwater flows within Piedmont rocks at depths in excess of $300 \mathrm{~m}(1,000$ feet). Hydrogeologic studies that have been performed in the Piedmont have generally been restricted to the upper consolidated soil and fractured rock. It is expected that with increasing depth, joints and fractures become fewer and tighter, resulting in more restricted groundwater flows (Snow, 1968). However, joints, shears, and fractures are common in all crystalline Piedmont rocks and the transmissibility to groundwater within the various rocks will depend on rock type, chemical and physical composition, and tectonic history. 01 der rocks that have been subjected to multiple periods of deformation may tend to be more highly fractured than younger, intrusive rocks. Similarly, the more massive high-grade metamorphic rocks (granites and gneisses) that have been recrystallized and compacted are expected to have lower permeabilities than the lower grade metamorphic rocks.

The regional groundwater table throughout the Piedmont is generally a subdued replica of the topography. Groundwater gradients are dictated by topographic expressions with regional movement being from the higher elevation towards lower elevations.

Locally, deep groundwater circulation is affected by rock types and structural discontinuities. Areas with faults and contact zones between igneous and metamorphic rocks will generally produce substantially higher groundwater yield in comparison to other areas within the region (Herrick and LeGrand, 1949).

In general, it is to be expected that the large younger igneous intrusive rocks and the more massive high-grade metamorphic rocks would be most likely to have the lowest permeabilities of all the Piedmont rocks.

\section{7 - Natural Resources}

The Piedmont is endowed with a variety of rocks and minerals that have been of economic importance since colonial days. Both metallic and non-metallic minerals are found within the province. 
The metailic minerals are principally associated with the igneous and metamorphic rocks. Minerals, including chromite, copper, gold and silver, iron, lead and zinc, manganese, molybdenum, nickel, tin, titanium and tungsten occur in limited quantities throughout the Province, while some high-grade magnetite is found locally. The Piedmont is not considered a large producer of metallic minerals, and only small localized mines are currently in operation. However, because of its similarity to important metal mining districts in Canada, the Carolina Slate Belt (see Section 3.2.5) has been the target of recent exploration, and has been considered to have potential for the discovery of sulfides deposits to include copper, lead and zinc (Wilson, 1976). However, no major deposits have been found to date.

The largest and most productive mining within the Piedmont are the nonmetal1 ic resources. This industry is highly diversified and found throughout the Province. The principal non-metallic resources are:

- Feldspar - Mica

- Lithium

- Crushed Stone

- Dimension Stone

- Talc and Pyrophyllite

- Asbestos

- Gemstones

The potential effect on current and future development of natural resources within the Piedmont rocks must be thoroughly assessed for the siting of a waste repository. 
4 - CRITERION FOR SELECTING POTENTIAL GEOLOGIC FIELD STUDY AREAS

\section{1 - Introduction}

This section discusses the technical criteria used in identifying potential host rocks that may be favorable for exploration for underground disposal of waste material. The criteria are based on the concept that a host rock for a proposed repository site must have adequate chemical and physical properties to insure long-term geologic containment of any stored radioactive waste such that the radionuclides would be isolated and thus dispersion into the biosphere in hazardous amounts would be prevented.

Generally, qualitative rather than quantitative parameters have been used in these criteria because:

(a) no regulatory guidelines for deep disposal of radioactive wastes have yet been developed;

(b) the required effective period of isolation of the waste material from the biosphere has not been determined; and

(c) the effects of radioactive waste/rock interaction for the Piedmont rocks has not been determined.

A suitable host rock for housing a radioactive waste repository must ultimately demonstrate favorable hydrogeology, geology and geotechnical conditions. This study utilized these three disciplines in defining favorable rock units within the southern Piedmont. Rock units having favorable properties were referred to as "potential study areas" which indicates that they provide the highest potential for locating a suitable rock mass with in that body for siting a repository.

The study areas have been designated solely on their technical acceptability with no consideration being given to socioeconomic or nontechnical factors at this time. It is realized that land-use conflicts are a political consideration that will have to be addressed at an early phase of any 
subsequent studies undertaken to evaluate the "potential study areas". Obvious conflicts with urban areas, national parks, densely populated areas, etc., will eliminate many technically acceptable rocks from further consideration.

The three technical criteria--hydrogeology, geotechnical conditions and geology were subdivided into those properties and conditions that were considered most crucial to assure the long-term stability and containment of radioactive waste material. These included:

I Hydrogeology: Permability

Hydraulic Gradient

I Geotechical:

Physical and Mechanical Properties

Unconfined Compressive St rength

Modulus of Elasticity

Rock Quality

Joint Spacing

In-situ Stress

II Geology: Unit Dimension

Structural Complexity

Lithology

The thermal properties of a rock, including its thermal conductivity, specific heat capacity and geothermal gradient, are important in the ultimate selection of a potential host rock. However, for this study a rock's thermal properties have not been considered because:

- these properties are poorly defined for Piedmont rocks,

- the majority of the otherwise favorable rock units considered in this study are believed to fall within acceptable ranges of thermal properties and, 
- the degree and duration of thermal loading is related to the type to be disposed which is unknown at this time.

\section{2 - Hydrogeology}

The primary vehicle for migration of radionuclides from a repository to the biosphere is the groundwater system. Thus, to insure the long-term isolation of radionuclides from the biosphere, the hydrogeology of potential sites must be thoroughly understood. Hydrogeologic conditions, including groundwater flow patterns, rock mass permeability, hydraulic gradients, linear velocity and the content and retention of radionuclides within the rock, must be thoroughly evaluated.

The groundwater flow pattern (upward, downward or lateral movement) is crucial to the siting potential of a repository. The host rock must safeguard the waste from disseminating into the biosphere. Such data in the Piedmont are generally scarce, and available only within a few hundred meters of the ground surface. It is generally difficult to extrapolate near surface data to depths. However, certain geological characteristics (e.g., nature and orientation of joints, foliation, mechanical properties and tectonic history of rocks, etc.) can help guide the initial selection of potentially favorable hydrogeological areas. In light of the absence of hydrogeological data, intensive investigations will have to be carried out during any future field study program.

As stated in Section 3.6, the groundwater flow within the Piedmont rocks is generally restricted to connecting joints, fractures, and shear zones within the rock bodies. It is, therefore, important to identify those rock bodies that are massive and homogeneous with minimal jointing, fracturing, and shearing. Rocks that may meet this criteria in the Piedmont are the younger, intrusive granitic rocks and the more massive, less foliated, highgrade metamorphic rocks (i.e., granites and gneisses). Many of the Precambrian and early Paleozoic rocks of the Piedmont have been subjected to multiple periods of metamorphism and hard rock deformation causing their intense fracturing, shearing and alteration resulting in higher rock permeabilities. 
Some systematic jointing of a rock mass (resulting from cooling of the rock mass or from regional stresses) are expected to be found in the younger Piedmont intrusive and high-grade metamorphic rocks. In general, however, because of these rocks younger age and/or metamorphic history, the degree of fracuturing and jointing is expected to be appreciably less than that of the older Piedmont rocks. Both the spacing and openness of joints and fractures seen on the surface are expected to decrease with depth due to increasing confining stresses and decreased effects of weathering (Snow, 1968).

Thus, the crystalline rocks that appear to demonstrate the most favorable hydrogeology for housing a nuclear repository within the southern Piedmont are the large, young, granitic plutonic and massive high-grade metamorphic rocks that are believed to extend to depth.

\section{3 - Geotechnical}

The geotechnical parameters which are considered to be of importance in assessing the overall suitability of a host rock for storage of radioactive waste include both physical and mechanical properties. The host rock should provide the following conditions to ensure the overall integrity of a waste repository:

(a) adequate rock properties to assure long-term stability of mined
chambers

(b) adequate rock composition such that any alteration of the host rock caused by radiogenic heat, radiation, or air and/or water would not adversely affect repository stability

(c) adequate physical properties to assure no deterioration of the original low permeability of the rock. 
Table 3 provides a general range of key physical and mechanical properties considered important in the selection of a potential host rock for exploration for radioactive waste disposal. These ranges, which are qualitatively stated and are referenced to accepted engineering parameters (Appendix A), cover a variety of rock types. These values are only intended to provide general guidelines in defining overall rock suitability. Rocks that deviate from these ranges should not necessarily be excluded from further consideration.

Generally, the mechanical properties of rocks with complex structural geology vary throughout the individual rock unit. Many of the Piedmont metamorphic rocks, including phyllites, slates and volcanic rocks, have anisotropic properties resulting from the variations in these physicalchemical properties. These rocks may exhibit low compressive strength, overall poor rock quality, locally adverse in-situ stress conditions and relatively high natural moisture content. Because of these poor qualitites, many of these rock types are expected to undergo deterioration in strength on exposure to air and these rock types were therefore generally considered unfavorable for housing a radioactive waste repository.

The most favorable Piedmont rock types that fall with in the desirable ranges of physical and mechanical conditions outlined in Table 3 are the younger granites, gabbros, granodiorites and some gneisses. Many of these rocks are massive and isotropic in nature, and are of high rock quality with excellent mechanical properties for excavating and sustaining large underground openings.

\section{$4.4-\underline{G e o l o g y}$}

A host rock must not only be of sufficient lateral and vertical dimensions to house a repository but large enough to provide a "buffer zone" that would effectively prevent the migration of radionuclides to the biosphere. The size of a host rock body is obviously dependent on the amount of waste to be stored and the mined chamber configuration which may be dictated by the 
rock's physical, chemical, mechanical and thermal properties. Thus, the larger and more homogeneous the rock mass, the greater the opportunity for siting a repository within the rock mass at a sufficient distance from geologic contact zones or other discontinuities that may have relatively high permeabilities.

The vertical extent and continuity of individual rock units within the Piedmont are poorly defined. As previously stated, the intent of this study was to locate potentially favorable host rock bodies suitable for exploration for a radioactive waste repository. Thus, only those large, massive mapped rock bodies of $100 \mathrm{sq.km}$ (40 square miles) and larger in size that were believed to be continuous to depths in excess of $300 \mathrm{~m}(1,000 \mathrm{feet})$ were considered as favorable study areas. Smaller units, which demonstrated satisfactory geotechnical and hydrogeologic conditions, were generally eliminated from further consideration because of insufficient size for excavation for a repository and provision of a buffer zone within the same rock type. However, additional work on these small units may subsequently indicate that some of them have excellent potential for exploration.

Many of the mapped units within the Piedmont are a grouping of diversified lithologies. Some of these lithologies may meet the criteria for exploration for a waste repository; however, the areal and vertical extents of these individual lithologies are unknown. Additional work in these areas may identify additional study areas with potential for exploration.

The seismicity of the southern piedmont was assessed (as discussed in Section 3.5) and no obvious correlation between earthquakes within the Piedmont and geologic structures or tectonic features (i.e., faults or foids) was identified. There are no known active faults within the study areas. Seismicity within the Piedmont is considered to be low to moderate with earthquakes occurring more or less randomly within the Province, and as a result, seismicity is not considered a major limiting criterion for site selection in the Piedmont. Underground structures, as contrasted to surface 
facilities, have additional support that minimize and dampen the impact of earthquake vibrations. No insurmountable seismic design problems are anticipated for either the mined chambers or above ground facilities. However, the seismiscity of areas close to historic epicenters must be addressed in subsequent studies. 


\section{1 - Introduction}

This section contains a discussion of the methodology used in applying the criteria outlined in Section 4, to select potential study areas for radioactive waste disposal. The crystalline Piedmont rocks in Maryland, Virginia, North Carolina, South Carolina and Georgia were individually assessed as to their potential for study areas.

\section{2 - Criteria Application}

Due to the limited scope and large geographic area covered by this study, a consistent review, classification, and grouping of rock types within the southeast states was required.

Based on the criteria established in Section 4 for the selection of potential host rocks for radioactive waste disposal, the Piedmont rocks were grouped by their original and overall suitability as:

Igneous Plutonic

Metamorphic

Sedimentary

Volcanic and Metamorphic Volcanic

Each state was reviewed on an individual basis, since most of the geologic literature, stratigraphic nomenclature, and maps were limited by state boundaries. Each state geologic map was reproduced and used as the point of reference in defining the individual rock units or types within each state.

Different philosophies in geologic mapping were used in constructing the various geologic state maps. Maryland, Virginia and North Carolina, for the most part, classified rocks by their formation names, while the South 
Carolina and Georgia maps were based on grouping of rocks by type. These variations in mapping created difficulty and, in some cases, inconsistencies in correlating rocks across state boundaries. Each individual rock formation or type within the state was tabulated and described by age, type and petrologic description (where available), and classified for its overall hydrogeologic, geologic, and geotechnical suitability, as defined by the criteria (see Section 4 ).

This was accomplished with the use of the following five major categories that were used for rapid classification of individual rock units:

- Hydrogeo logy

- Physical and Mechanical Properties

- Geology Unit Areal Dimension

Structure

Lithology

Each rock formation or type was individually assessed for its overall suitability under each of these headings and was classified as either "acceptable", "marginally acceptable", or "unacceptable" in each category. When no data was available, this fact was indicated. Classification was based on rock descriptions as found in the literature and discussions with members of the various state geological surveys.

An "acceptable" classification meant that, with currently available information, the specific rock unit appeared to demonstrate favorable properties and/or conditions for exploration for a waste repository as defined by the criteria. A "marginally acceptable" rank classified those rocks that may be found to demonstrate locally acceptable conditions following more detailed studies. As previously stated, many of the rocks in the Piedmont have been grouped by rock type rather than by formation. Since a differentiation of potentially suitable rock formations within these groups was not within the scope of this study, these rocks were generally marked as "marginally acceptable" under the lithology category and either "acceptable" or "marginally 
acceptable" under the lithology category and either "acceptable" or "marginally acceptable" under the Unit Areal Dimension category depending on the general rock description and its areal extent. Rocks that were subjected to multiple periods of deformation and metamorphism and described as being fractured were generally ranked as "unacceptable" under the structure category. The age, type, and general history of a rock unit was individually assessed in defining the rock's ranking under the hydrogeology and physical and mechanical properties categories. The scope of this study was to grossly categorize and identify potential field study areas. Thus, subsequent field studies may well identify locally "unacceptable" properties and/or conditions within an "acceptable" ranked unit, or vice versa.

Upon completion of categorizing each individual rock unit within a state, the amount, type, and impact of the "marginally" and "unacceptable" condition(s) were individually assessed and each rock unit was classified overall as either "favorable", "potentially favorable" or "unfavorable". Those rocks classified as "favorable" were considered to indicate the highest potential for finding a suitable rock mass within the rock body. Those rocks that were classified as "potentially favorable" were those rocks that appeared to indicate acceptable properties and/or conditions; however, extensive time and effort would be required to locate suitable study areas within these units. For this reason these rocks were considered to provide a lower degree of confidence for locating a study area than the "favorable" units. Those rocks that were considered totally unsuited were classified as "unfavorable".

The categories having the greatest impact on defining the overall favorability of a rock was its Unit Areal Dimension and Hydrogeology. Many otherwise suitable rocks not having sufficient surface areal size, as defined by the criteria, were given an "unfavorable" ranking. Supplemental information may show these rocks to increase in area with depth which could change their overall classification to a "favorable" ranking. Rocks described as being highly fractured and deformed were generally ranked "unfavorable" for hydrogeologic conditions. 
In the case where a rock ranked as "favorable" was mapped in more than one area of a state, then only those rock bodies meeting the $100 \mathrm{sq} . \mathrm{km}$ (40 square miles) areal dimension criterion were selected for field study areas unless the body was in contact with other "favorable" or "marginally favorable" rock units.

Rock units of this size were considered to provide:

- a higher degree of confidence that the rock was continuous to depths in excess of $300 \mathrm{~m}(1,000$ feet),

- a sufficient area for potential repository(ies), and,

- sufficient area for an adequate buffer zone between a proposed repository and the contact zones.

\section{3 - Maryland}

\subsection{1 - General Geology}

The Maryland Piedmont extends from the Coastal Plain westward to the Blue Ridge, a distance of approximately $65 \mathrm{~km}(40 \mathrm{miles})$. The stratigraphic sequence of the Maryland Piedmont consists of the Precambrian (>600 million years ago) basement (Baltimore Gneiss) which is overlain by the metamorphosed stratified rocks of the Glenarm series, a sequence of late Precambrian schists, gneisses, marbles and metagraywackes of the Setters Quartzite and Cockeysville Marble and the Wissahickon formations. Mapping the Glenarm rocks is difficult because of their complex sedimentary facies relationships, variable metamorphic grade, intense and repeated deformation, and the lack of distinctive lithologic units (Fisher, 1970). The sedimentary sequence of the Maryland Piedmont rocks reflect a long and complex history of sedimentary depostion. Mapping of structures along the Potomac (Fisher 1970) reveals a complex history of deformation with evidence of syndeposition and post-deposition folding interspersed with periods of metamorphism. 
Across the Maryland Piedmont, the grade of regional imetamorphism changes progressively, from the chlorite zone in the west to the kyanite and sillimanite zones in the east. There is also a varied assemblage of plutonic rocks, consisting of ultramafic and gabbroic rocks, as well as a wide range of granitic rocks (Hopson, 1964). The southeast section of the Maryland Piedmont is made up of gneisses, quartzites, schists, and granites or mafic rocks, while the northwest is underlain by phyllites, slates and much less altered formations. Unaltered Triassic rocks crop out along the bend in the Potomac River in the vicinity of Rushville, Maryland.

\subsection{2 - Potential Field Study Areas}

Based on the criteria presented in Section 4, Maryland Piedmont rock units were evaluated for potential field study areas (see Table 4) and are shown on the State Geologic Map, Plate 6.

Because of the inadequate areal dimensions and/or complex metamorphic and structural history of the rock units, no "favorable" study areas were found within the State of Maryland. Several "potentially favorable" study areas that were identified include:

- Sykesville Boulder Gneiss (wbg)

- Baltimore Gneiss (p€bg)

- Woodstock Quartz Monzonite (PzW)

- Baltimore Gabbro Complex (bgb)

Although the woodstock was considered insufficient in areal dimensions, it was included as "potentially favorable" because of its immediate proximity to the larger Baltimore Gneiss formation.

The Sykesville Formation (wbg) extends in a broad belt from the southeastern corner of Carroll County into east-central Montgomery County. The rock consists of a heterogeneous group of pebble-and-boulderbearing arenaceous to pelitic metamorphic rocks (Hopson, 1964). The rock ranges from a medium-grained weakly gneissic granite to a nearly 
massive rock that resembles dark, impure quartzite. Foliations range from very weak to strong. Large inclusions of metagraywackes, mica schist, amphibolites, calc-silicates, ultramafics, and gneisses to granites are found within the rock mass.

The Baltimore Gneiss (p\&bg), which is the oldest rock in the Maryland piedmont, crops out in seven anticlinal domes and along the Coastal Plain (see Plate 6 ). The Baltimore Gneiss rocks include a wide variety of rocks of varying ages and origins. It is a complex assemblage of quartzo-feldspathic gneisses, amphibolites, migmatites, and gneissic granitic rocks and is extremely varied in texture and structure (Hopson, 1964).

The Woodstock Quartz Monzonite $(P z W)$ is a very small oval intrusive stock of massive biotite quartz monzonite which intrudes the center of a Baltimore Gneiss dome (see Plate 6). Quarrying operations show a well-developed horizontal sheet structure and vertical near-surface jointing. The rock has a well-developed hypidiomorphic granular texture showing the normal magmatic crystallization sequence (Hopson, 1964).

The Baltimore Gabbro Complex (bgb) is a large mass of mafic and ultramafic rock that crops out in the western part of Baltimore City and adjacent parts of Baltimore County and extends southward into Howard County. Hopson (1964) interprets the Baltimore Gabbro as an intrusion of magma at the earliest stage of orogeny which was subsequently caught up in compressional folding, gneiss doming and regional metamorphism during the late stages of its crystallization. Recent theory is that the Baltimore Gabbro was emplaced on multiple thrust slices. The thickness of the unit is unknown, but if the thrusting hypothesis is correct, the rock may not be of sufficient thickness to meet the criteria for a radioactive repository. 
As is the case with the majority of the Piedmont rocks, there is no information concerning the deep hydrogeologic regime of these rock units. Based on their history and origin, it is expected that they are continuous to depths of $300-1200 \mathrm{~m}(1,000$ to 4,000 feet $)$. Additional studies and investigations may identify suitable portions of these units as being potentially favorable for further study.

No other Maryland Piedmont rocks warranted further consideration because of their limited areal extent or adverse chemical, physical, structural or lithologic properties.

\section{4 - Virginia}

\section{4 .1 - General Geology}

The Virginia Piedmont lies within the middle of the State and ranges in width from $50 \mathrm{~km}$ (30 miles) at the Virginia-Maryland border to nearly $320 \mathrm{~km}$ (200 miles) at the Virginia-North Carolina border. The Piedmont is bounded on the east by the Coastal Plain and on the west by the Virginia Blue Ridge Complex, a series of Precambrian (>600 million years ago) granites and gneisses. The piedmont includes a diverse assemblage of Paleozoic (600-230 million years ago) granites, granodiorites, augen-gneisses, granite gneisses and metamorphic rocks consisting of schists, slates, phyllites, quartzites, marbles, metamorphosed arkoses and conglomerates, greenstones, diorites and gabbros, with metamorphosed volcanic rocks. Cutting all of these rocks are a series of Triassic age (200 million years ago) basins which generally trend along the regional structure, northeast-southwest.

Like the remainder of the southern Piedmont, the Virginia Piedmont has experienced a complex series of tectonic and metamorphic activity which commenced in the Precambrian and continued through the Mesozoic. 
Normal faults are found in association with the Triassic basins throughout the Virginia Piedmont, while Pre-Mesozoic thrust faulting can be found along the Piedmont-Blue Ridge Complex. None of these faults are considered active. However, any fault located in proximity to a "favorable" study area should be investigated to define its local effects on the groundwater regime.

\section{4 .2 - Potential Field Study Area}

Based on the criteria presented in Section 4, Virginia Piedmont rock units were evaluated for potential field study areas (see Table 5) and are shown on the State Geological Map, Plate 7.

The only "favorable" study area identified in the state of Virginia was the:

\section{Petersburg Granite (Pzpb)}

The Petersburg is a large batholithic intrusive which extends from Hanover County, southward into North Carolina (Bloomer, 1939). The Petersburg intrudes amphibolite-grade metamorphosed sedimentary and volcanic rocks of uncertain age. The intrusion is bordered on the west by Triassic basins and on the east by the Coastal Plain. Lithologically, the Petersburg consists of three distinct facies; a gray to pink, medium-grained granite; a blue, relatively fine-grained facies; and a porphyritic granite. The rock is primarily composed of quartz, potassium feldspar, oligoclase and biotite. Dating of zircons from the Petersburg gives an age of approximately 330 million years ago (Wright, et al, 1975). Petrographic and field relations indicate that the Petersburg was probably only slightly affected by metamorphism indicating that it may mark a minimum age of metamorphism within the Virginia Piedmont (see Section 3.3).

Structural features with in the Petersburg are vague. Three joint sets ( 2 horizontal and 1 vertical) have been mapped in the unit. The extent and effects of the Triassic faulting on the west side of the intrusion must be assessed in further studies of the area. 
Three rock units classified as "potentially favorable" were the:

Granite gneisses (grgn)

Granites ( $g r)$

Redoak Granite (PzpGro)

The granite gneisses (grgn) are described in the Hylas and Midlothian Quadrangles (Goodwin, 1970) as being relatively uniform, even banded, and well-foliated. In some cases the granite gneiss is integrated with dark gray, fine- to medium-grained, biotite rich, intensively foliated, schistose textured giotite gneisses. The age of these rocks may be Precambrian (>650 million years). The gneisses are jointed and in many places have well-developed foliations. Pegmatite dikes up to $\operatorname{lm}$ (3 feet) width occur within the rock.

The granites ( $g r$ ) of undetermined age, are described as being biotite and muscovite granite, granodiorite and quartz monzonite. This unit includes the columbia granite. The composition of this rock type varies locally, with the unit being more massive in the northern section of the state. South of the James River, the rock becomes badly fractured and foliated (personal communications, Virginia Geological Survey).

The Redoak Granite (Pzp6ro) is a biotite and muscovite granite, granite gneiss with feldspar and chlorite granodiorite. These rocks are found in the south-central section of the state and extend into North Carolina. These rocks are considered "potentially favorable" if considered as part of the granites (gr) mapped in North Carolina (see Section 5.5).

The varied properties and condition of these rock bodies has warranted a classification of "potentially favorable". As previously stated, extensive time and effort would be required to locate a suitable repository locally within these rock masses.

The hydrogeology within these rock units is unknown. As in other states within the southern Piedmont, no deep wells have been drilled to define the hydrogeologic regime and/or rock mass permeability. Although many of the rock bodies are jointed, it is expected that permeability will decrease with depth. 


\section{5 - North Carolina}

\section{5 .1 - General Geology}

The North Carolina Piedmont covers approximately 40 percent of the State, extending from the Coastal Plain westward to the Blue Ridge, and includes the Carolina Slate Belt, the Charlotte Belt, Kings Mountain Belt and the Inner Piedmont Belt. A detailed description of these belts is presented in Section 3.2 and shown on Plate 2 . In summary, the Carolina Slate Belt occupies a large part of the North Carolina Piedmont and is divided into two segments by a series of Triassic basins. The largest or western segment transects the middle part of the state, structurally trending in a northeast-southwest direction. The eastern segment, which contacts the Coastal plain, consists of volcanic sedimentary formations composed of slates, breccias, tuffs and flows that, in places, have been intruded by granitic plutons.

The Charlotte Belt, which contacts the Carolina slate Belt on the west, contains more granites than the other belts with abundant granitoid rocks and intrusive plutons.

Rocks of the Kings Mountain Belt, which forms an elongated section in the west central part of the state, are generally less metamorphosed than the adjacent belts and retain a remnant of their original sedimentary characteristics. These rocks are mostly quartzites, schists, conglomerates and marbles.

The western Inner Piedmont Belt is the oldest and least understood of the Piedmont Belts. The rocks of this belt have been highly metamorphosed which has made their origin, sequence and geologic history difficult to decipher. 
The North Carolina Piedmont has had at least 3 periods of intrusive events; 595-520, 415-385 and 300 million years ago. The early Paleozoic intrusives (595-620 million years ago), which are found in the Inner Piedmont Belt, have been highly deformed and subjected to retrogradation from subsequent tectonic and metamorphic events. The youngest intrusive rocks (approximately 300 million years ago) have intruded the metamorphosed rocks of the Charlotte and Carolina slate Belts (Fullagar, 1971a). These younger plutons are generally post or syn-metamorphism.

Several major faults have been mapped within the North Carolina Piedmont. These include the Jonesboro Fault, Gold Hill Fault, the Brevard Fault Zone. Other faults are inferred beneath the Coastal Plain (see Section 3.3 and Plate 3 ). The Jonesboro Fault is of Triassic age (180 million years ago) and forms the east side of the Triassic basin. The Gold Hill Fault is a zone of shearing and cataclasis within the Charlotte-Carolina Slate Belt that extends from North Carolina-South Carolina border northeastward for approximately $135 \mathrm{~km}$ (80 miles).

The Brevard Fault Zone (see PIate 3), marking the boundary between the Piedmont and the Blue Ridge Province, extends for more than $520 \mathrm{~km}$ (325 miles) with a width of $5 \mathrm{~km}$ ( 3 miles). The history and movement of the fault is complex with movement probably consisting of a combination of strike-slip and thrusting.

All of these faults are Paleozoic to Mesozoic in age. Movement of these faults was believed to have terminated by the Mesozoic period. No recent seismicity is known to be associated with these structures. However, any fault located near a proposed study area should be fully investigated for its potential adverse effect on the local hydrogeologic regime. 


\subsection{2 - Potential Field Study Area}

Based on the criteria presented in Section 4, North Carolina rock units were evaluated for potential field study areas (see Table 6) and are shown on the State Geological Map, Plate 8.

The classification of rocks on the state geologic map for North Carolina are based on rock type, rather than specific formations and units. This simplification of grouping many rock types of various ages, composition and tectonic history into one classification made specific rock unit selection difficult. The identification of "favorable" study areas within these broad groups could only be done based on general rock descriptions provided in the literature and discussions held with knowledgeable persons. Only those areas that appeared to be the most desirable for exploration and cover an area in excess of $100 \mathrm{sq}$. km (40 square miles) were classified as "favorable". All other rock types were classified as either "potentially favorable" or "unfavorable". As previously stated in Section 4, many suitable areas within "potentially favorable" areas may be found during further work.

The most favorable rock category identified in North Carolina is the igneous plutonic granites (gr). These cover a large geographic area, ranging from the Coastal Plan to the Blue Ridge. Within this category are three plutonic bodies which were considered as "favorable" study areas. These were the:

Rolesville Batholith

Churchland Pluton

Landis Pluton

The Rolesville Batholith covers an area of approximately 1700 square km (650 square miles) (Butler and Ragland, 1969) east of Raleigh in the eastern Piedmont of north-central North Carolina. The majority of the batholith is comprised of a medium- to coarse-grained, fol iated granite. The northeast side of the batholith is generally unfoliated, coarse-grained quartz monzonite constituting a nearly separate lobe, 
called the Castalia Pluton (Becker and Farrar, 1977). The batholith has intruded metasedimentary and metavolcanic rocks of granitic gneisses, muscovite and muscovite-biotite schists. The age of the Castalia Pluton has been dated as $316 \pm 6$ million years (Julian, 1972). Jointing is common but not excessive. Where exposed, the granite appears in either ridge or dome-shaped masses. Residual soils cover ranges from less than 1 metre to as much as 12 metres (up to 40 feet.)

The Churchland and Landis Plutons, located in the Central Piedmont Granite Belt, have been mapped by Butler and reported in Heffner and Ferguson (1978) as post metamorphic (300 million years old) intrusives (see Plate 8). These plutons are described as being coarse-grained to porphyritic in texture with ground mass consisting of feldspar, quartz, and biotite. A complex relationship exists between the granites in this area and the diorites. Detailed work would be required to accurately define the age and structural relationships within this area.

Rocks classified as "potentially favorable" study areas in North Carolina included the:

- Granites (gr) in the central and western Piedmont

- Diorite - gabbros (digb)

- Henderson Granite Gneiss (hgg)

- Granite gneiss complex (gnc)

- Whiteside Granite (wg)

The granties (gr) mapped within the central and western Piedmont of North Carolina vary in area, age, and composition. Granites exposed in the north-central part of the Piedmont have been described as being locally crushed and broken with the development of a schistose or gneissic structure extensively intruded by basic dikes (Stuckey, 1958). 
Granites in the south-central North Carolina Piedmont vary in composition from granites to diorites. Many of these granites have considerable gneisses and schists in association with them and are medium to highly jointed and fractured.

The granites of the western Piedmont Belt are generally medium to fine-grained biotite granite consisting of orthoclase, plagioclase, quartz, biotite, a little muscovite, and minor accessory minerals. They vary from massive granites to gneissic and schistose rocks.

The diorite-gabbro ( $\mathrm{di} \mathrm{gb}$ ) is confined largely to the central Piedmont and is generally associated with the granites. The rocks of this unit range locally from diorite to gabbro. The rock is coarse-textured and is distinctly massive with closely spaced joints. It is composed of hornblende or pyroxene, plagioclase, and varying amount of quartz and accessory minerals. The rock is generally covered by thick soil covers (Stuckey, 1958).

The Henderson Granite Gneiss (hgg) is an older granite gneiss found in the southwest portion of the Inner Piedmont of North Carolina. The age of this rock has been dated at 538 million years (Odom and Fullagar, 1973). The rock has pronounced gneissoid structures. Mineralogical$1 y$, the rock consists of orthoclase, plagioclase, quartz, muscovite, and biotite. This unit has been greatly altered by metamorphism. Weathering of the Henderson Granite Gneiss varies widely (Stuckey, 1958).

The granite gneiss complex (gnc) is described as a medium to very coarse gneissic granite, containing mica gneiss, mica schist and hornblended gneiss. The unit also contains granite gneisses similar to the Henderson Granite Gneiss and younger granites (Stuckey, 1958).

The Whiteside Granite ( $w g$ ) is exposed in the southwest portion of the Inner Piedmont. The areal extent of this unit in North Carolina does not meet the criterion for this study; however, since it extends into South Carolina, it is considered to be a "potentially favorable" study area. The granite is a light-gray, even-grained, massive rock, 
consisting of orthoclase, plagioclase, quartz, muscovite, biotite and minor amounts of magnetite, ilmenite, and garnet (Stuckey, 1958). The granite has intruded older rocks and appears to parallel foliations.

\section{6 - South Carolina}

\subsection{1 - General Geology}

The South Carolina Piedmont includes the western half of the state and contains over 95 percent of the crystalline rocks within the state. The Blue Ridge occupies the extreme western tip of the state and is separated from the Piedmont by the Brevard Fault Zone.

As in other southern Piedmont states, the South Carolina Piedmont is poorly understood due to a thick cover of saprolite and the scarcity of detailed geologic mapping.

The South Carolina Piedmont includes the Carolina Slate Belt, Charlotte Belt, Kings Mountain Belt and Inner Piedmont Belt. A detailed discussion of these belts is presented in Section 3.2. In summary, the eastern-most of these belts consists of the low-grade metamorphic rocks of the Carolina Slate Belt. The rocks of this belt are mostly in the muscovite-chlorite and biotite-chlorite subfacies of the greenschist facies. Large plutons, some metamorphosed and some apparently unmetamorphosed, are present in the belt. The belt extends from the Costal plain northwestward merging with the gneisses, schists, and granitoid rocks of the Charlotte belt.

The broad Charlotte Belt extends from the Carolina Slate Belt northwestward to the Kings Mountain Belt. This belt contains more granites than the other belts. Local metamorphic grades rise to the starolite-kyanite and sillimanite-almandine subfacies of the almandine-amphibolite facies (0verstreet, 1970). The belt is also notable for its swarms of mafic dikes. The Charlotte Belt is a zone of moderate metamorphic grade between two belts of lower-grade rocks. 
The kings Mountain Belt consists of sericite schist, hornblende schist, quartzites and marbles. These rocks trend in a narrow belt through the central part of the South Carolina Piedmont.

The widest of all the belts in South Carolina is the Inner Piedmont Belt. This belt is bounded by the Kings Mountain Belt on the southeast and the Brevard Fault Zone on the northwest. The belt has a high degree of metamorphism which has made its origin, sequence and geologic history difficult to decipher.

Three episodes of igneous intrusions are recognized in the South Carolina Piedmont (Overstreet \& Bell, 1965). Butler and Ragland (1969) have divided three episodes into pre-, syn-, and post-metamorphism.

The first episode, and least known, may have taken place in either late Precambrian or Cambrian time (595-520 million years ago). The second, and strongest, probably occurred during the Silurian (415-385 million years ago), occurring pre- and syn-late stage metamorphism, and the third and last episode probably occurred during the Carboniferous (300-250 million years ago). The rocks of most interest for this study are the granitic intrusions of the last episodes. These are, for the most part, large felsic plutons, circular to oval in plan and found in the Carolina slate and Charlotte Belts.

The South Carolina Piedmont has been deformed into a series of synclinoria and anticlinoria, trending in a general northeastsouthwest direction. The province is cut by several major fault systems to include the Brevard Zone, Towaliga and Goat Rock and Gold Hill Faults, as well as the several recently mapped faults along the Fall Line and beneath the Coastal Plain. A description of these faults is presented in Section 3.4 and shown on Plate 3 . 


\subsection{2 - Potential Field Study Areas}

Based on the criteria presented in Section 4, the South Carolina Piedmont rock units were evaluated for potential field study areas (see Table 7) and are shown on the State Geological Map Plate 9.

As stated in Section 5.2, the South Carolina geological map was based on grouping of rock type rather than by formation or units, which posed some difficulties in identifying specific "favorable" and "potentially favorable" rock bodies (i.e. plutons) within the rock types.

Based on a literature survey and discussions with knowledgeable persons, three igneous plutons were identified as "favorable" study areas in South Carolina. These were the:

- Liberty Hill PIuton

- Winnsboro Complex

- Ogden Pluton

The Liberty Hill Pluton (Plate 9) which lies in north-central South Carolina in Kershaw, Lancaster and Fairfield Counties, has been dated at approximately 300 million years old (Fullagar, 1971a). The pluton, which appears to be post metamorphic in origin, has 3 textural phases: a very coarse biotite-amphibole granite and quartz monzonite, a porphyritic border phase, and a fine-to-medium grained biotite granite which intruded the western part of the pluton as large dikes and/or plugs (Costain, et al, 1977). This pluton intrudes rocks of the Carolina slate Belt, forming a discordant contact with the surrounding country rock.

Magnetic modeling of the Liberty Hill Pluton performed by Dunbar and Speer (1977) is consistent with an assymetric shape tapering inward with depth. Mapping suggests that the northwest boundary of the pluton is a normal fault that may be an extension of the Wadesboro Triassic basin (Be11 and Popenoe, 1976). Further investigation of this feature would be required in additional studies. 
The Winnsboro Complex which has been dated at approximately 300 million years old (Fullagar, 1971a), is also considered a post metamorphic igneous intrusive. The complex consists of two plutons. The rock is a medium-to-coarse grained granite, quartz syenite and quartz monzonite. Most of the complex lies within the Charlotte Belt whereas the southern border is in contact with the Carolina slate Belt (Wagener, 1970).

Both the Liberty Hill Pluton and the Winnsboro Complex are currently under investigation by the Department of Energy for the evaluation of geothermal energy resources in the southeastern United States (Costain, et a1, 1976-1977).

The Ogden Pluton, located in the southern portion of York and northern Chester Counties, has been mapped as middle Paleozoic (413 million years ago). The age of this gabbroic igneous intrusive body suggests that it was intruded pre- or syn- the last period of metamorphism. The rock is massive and locally intruded by augite syenite and syenite pegmatite.

Rocks considered "potentially favorable" in South Carolina are:

- Yorkville and Toluca Quartz Monzonites (Py \& Otm)

- Fine-grained Granite (POf) - Lowry's Pluton

- Porphyritic Granite (POp) - Lowry's Pluton

- Granitoid Gneiss (Ep\&g)

- Henderson Gneiss (DOhg)

- Biotite Granite Gneiss (DOgg)

- Biotite Gneiss and Migmatite (DpGm)

- Cherryville Quartz Monzonite (PMcq)

The Yorkville and Toluca Quartz Monzonites (Py \& Otm) are Paleozoic age porphyritic, massive to gneissic biotite quartz monzonites with the Toluca being garnetiferous. These rocks crop out in the north and north-central parts of the South Carolina Piedmont belt. Normally 
these rocks would have been classified as "unfavorable" because of their small area extent; however, due to their proximity to other potentially suitable rock types, they have been given a "potentially favorable" ranking.

The fine-grained granite (POf) and the porphyritic granite (POp) are massive, biotite granites, biotite-muscovite granites, quartz monzonites and porphyritic granites. These rocks crop out in a northeastsouthwest trend within the Charlotte Belt. The rocks include several of the older (pre-metamorphic) plutons dated around 400 million years old (Wright, et al, 1975).

The granitoid gneiss ( $\in \mathrm{p} \in g$ ) is a Cambrian group of undifferentiated granitoid gneisses, gneissic granodiorites, gneissic granites, biotite-muscovite schists and biotite-muscovite gneisses. This rock type includes a wide assemblage of rocks comprising the Charlotte and Carolina Slate Belts. Because of the diversified grouping of these rocks, extensive work would be required if locating suitable host rock bodies within this rock group.

The Henderson Gneiss (DOhg), Biotite Granite Gneiss (Dogg) and the Biotite Gneiss and Migmatite (DPEm) are varying granitic and gneissic rock types found within the Inner Piedmont Belt. These rocks have been subjected to high-grade metamorphism and multiple deformation causing a wide variation in chemical composition and structure.

\section{7 - Georgia}

\section{7 .1 - General Geology}

The Georgia Piedmont is a wide belt of metamorphic and igneous rocks which trend in a northeast-southwest direction across the northwest portion of the state. The province, as defined in this study, is bounded on the west by the Brevard Zone and on the east and southeast by the Fall Line (see Plate 2). The Province includes portions of the Inner Piedmont, Charlotte and Carolina Slate Belts (see Section 3.2). 
These rocks have been subjected to at least two periods of metamorphism. The metamorphic grade is low on the west and rises rapidly towards the southeast, remaining high all the way to the Fall Line.

Potassium/Argon age dates on the metamorphic rocks give ages of 250 million years, which appears to be the date of the last regional metamorphic event. Dates on rocks further to the west, which were less affected by the last metamorphism, tend to show older ages.

The Georgia Piedmont is cut by several major faults. These include the Brevard Zone, Towaliga Fault, and Goat Rock Fault (P1ate 3). These faults are discussed in detail in Section 3.3. In summary, the Brevard Zone is traceable for more than $520 \mathrm{~km}$ (325 miles) with a width generally less than $5 \mathrm{~km}$ ( 3 miles). The zone has had a long and complicated history with movement along the zone starting during the early Paleozoic (500 million years ago) and continuing through the middle Paleozoic (390 million years ago). The type of movement along the zone has been argued as being either strike-slip, thrusting; or a combination of both. Undisturbed Mesozoic age (200 million years ago) dikes which cross-cut the zone date its last known period of movement.

The Towaliga Fault dips to the northwest while the Goat Rock Fault dips to the southeast. These fault zones are traceable across Georgia, eventually disappearing beneath the Coastal Plain in Alabama. The apparent 1 ine of continuance of these faults suggests their last movement was post-metamorphic.

The Georgia Piedmont has had at least three periods of volcanism:

(1) pre-Mesozoic (>230 million years ago)

(2) Triassic or Jurassic (230-140 million years ago) and

(3) Upper Cretaceous or Lower Tertiary (85-50 million years ago) (Hurst, 1970). 
The pre-Mesozoic metavolcanics consist mainly of mestabasalts and metadacites and dikes ranging in composition from rhyolite to gabbro. This intrusive serjes was regionally metamorphosed towards the close of the Paleozoic (250 million years ago). The Triassic and Jurassic rocks are diabase dikes and possibly granophyric porphyries and hornblende andesites. These have not been metamorphosed.

\section{7 .2 - Potential Field Study Areas}

Based on the criteria presented in Section 4, the Georgia Piedmont rock units were evaluated for potential field study areas (see Table 8 ), and are shown on the State Geological Map, Plate 10.

As was the case in South Carolina, the Georgia geological map was based on grouping of rocks by type rather than by formation. This posed some difficulty in identifying "favorable" and "potentially favorable" rock bodies within the rock type and correlating rock units across state boundaries.

The most "favorable" geological field study areas in Georgia are the:

- Siloam Pluton (grlb)

- Elberton Pluton (gr2a)

- Other igneous granitic rock bodies (grl, gr2, grla, grlb)

These rocks are classified on the state geological map as undifferentiated granites, biotite granites and porphyritic and non-porphyritic granites. For the most part these rocks are pre-metamorphic or syn-metamorphic intrusive plutonic granites which have been intruded into older schists and metamorphic rocks.

The Elberton Pluton (gr2a), located in Oglethorpe and Elbert Counties, is described as a medium-grained light-gray granite, with its structure varying from gneissoid biotitic to massive. There are few data on this granite body; however, $\mathrm{Rb}-\mathrm{Sr}$ dates on nearby plutons give ages of approximately 270-300 million years (Jones and Walker, 1973). 
The Siloam Pluton (grlb) located in Greene County, is described as a medium-coarse-grained, light-gray granite (Watson, 1902). The pluton has been dated at $269 \pm 3$ million years old (Jones and Walker, 1973).

The granite in Warren and Hancock Counties (Sparta Pluton) is a coarse-grained porphyritic granite. Dates on this rock give ages of $535+25$ million years (Fullagar, 1971a).

Other "favorable" rock bodies are unnamed granite rocks in Douglas, Coweta, Spalding, Meriwether, Pike, Troup, Wikes, and Lincoln Counties (see Plate 10). These bodies have been designated as "favorable" study areas because of their large apparent massive structure and composition. Subsequent studies may show several of these older rock bodies to be severely altered and deformed by tectonic events giving them unfavorable hydrogeologic, mechanical and physical rock properties.

The "potentially favorable" rocks identified in the State of Georgia include a wide assemblage of the high-grade metamorphic granites and gneisses. The Georgia geologic map groups these rocks into three major categories:

- Granite gneiss (ggl, gg3-6) - undifferentiated, muscovite, amphibolite and calc-silicate granite gneisses and granite gneiss/granite

- Gneiss (fgl-4) - biotite, biotite-hornblende with amphibolite, undifferentiated, biotite with mica schist-amphibolite and biotite with amphibolite gneisses.

- Gneiss (bgl-4) - biotite, biotite-amphibolite, biotite-hornblendegranite and biotite with mica schist gneisses.

As stated in Section 4, these rocks may locally offer acceptable rock properties and conditions as a host rock for a radioactive waste repository; however, extensive time and effort would be needed to locate and evaluate a suitable rock mass with in these bodies. 
REFERENCES

- 


\section{REFERENCES}

Becker, S.W. \& S.S. Farrar, 1977, the Rolesville Batholith; in Evaluation and targetry of geothermal energy resources in the southeastern United States; Progress Report, November 1, 1976 - March 31, 1977, ERDA, Div. of Geotherma1 Energy, Cont. No. EY-76-S-05-5103.

Bel1, H. III and P. Popenoe, 1976, Gravity studies in the Carolina Slate Belt near the Hajle and Brewer Mines, north-central South Carolina; Jour. Res. U.S.G.S.: Bu11, no. 4, p. 667-682.

Bentley, R.D. and T.L. Neathery, 1970, Geology of Brevard Fault Zone and related rocks of the Inner Piedmont of Alabama; in Alabama Geol. Soc. Gujdebook 8th Ann. Field Trip: p. 1-80.

Bentley, R.D., T.L. Neathery, M.W. Higgins, and I. Zietz, 1974, Preliminary Interpretation of aeromagnetic and aeroradioactivity maps of the crystalline rocks of Alabama: Pt. 4, Geophysical evidence for major fault zones and associated meganappes in Alabama Piedmont (abs); Geol. Soc. Am. Abst. with Prog., v. 6; no. 4, p. 334-385.

Bloomer, R.0., 1939, Notes on the Petersburg Granite; Virginia Cons. Comm, Virginia Geologic Soc., Bul1. 51-F, p. 141-145.

Butler, J.R., 1966, Geology and mineral resources at York County, South Carolina; South Carolina State Devel. Board, Div. Geology Bull. vol. 33, $65 \mathrm{p}$.

Butler, J.R. \& P.C. Ragland, 1969, A petrochemical survey of plutonic intrusives in the Piedmont, southeast Appalachians, U.S.A.: Contrib. Min. Petrol., vol. 24, p. 164-190.

Clarke, J.W., 1952, Geology and the mineral resources of the Thomaston Quadrangle, Georgia; Georgia Dept. mines, Mining and Geology Bul1. 59, $99 \mathrm{p}$.

Costain, J.E. et a1, 1976, Evaluation and targeting of geothermal energy resources in the southeastern United States; Progress Report, May 1, 1976 - October 31, 1976, ERDA Div. of Geothermal Energy, Contract №. $E(40-1)-5103$.

Costain, J.E. et al, 1977, Evaluation and targeting of geothermal energy resources in the southeastern United States; Progress Report, November 1, 1976 - March 31, 1977, ERDA, Div. of Geothermal Energy, Contract No. E4-76-S-05-5103.

Crawford, T.J., and J.H. Medlin, 1970, Stratigraphic and structural features between the Cartersville and Brevard fault zones; Georgia Dept. of Mines, Mining and Geology, Georgia Geol. Soc. Guidebook, 37 p. 
Dunbar, J. and J.A. Speer, 1977, Magnetic modeling of the Liberty Hill Pluton and its contact aureole with comments on the mineralogy of magnetic phases; in Evaluation and targeting of geothermal energy resources in the southeastern United States; Progress Report, November 1, 1976 March 31, 1977, ERDA, Div. of Geothermal Energy, Contract No. E4-76-S-055103 .

Fenneman, N.M., 1938, Physiography of the Eastern United States; McGraw Hill Book Company, Inc. 714 p.

Fisher, G.W., 1970, The metamorphosed sedimentary rocks along the Potomac River near Washington, D.C.; in Studies of Appalachian Geology: Central and Southern: ed by G. W. Fisher, F.J. Pettijohn, J.C. Reed, Jr., \& K.N. Weaver; J. Wiley \& Sons, Inc., New York.

Fullagar, P.D., 1971, Age and origin of plutonic intrusions in the Piedmont of the southeastern Appalachians; Geo. Soc. Am. Bull., v. 82 , p. 2845-2862.

Glover, D.P., 1963, A gravity study of the northeastern Piedmont batholith of North Carolina; M.S. Thesis, Univ. of North Carolina, Chapel Hill, $41 \mathrm{p}$.

Goodwin, B.K., 1970, Geology of the Hylas and Midlothian Quadrangles, Virginia; Report of Inv. 23, Virginia Div. of Min. Res., 51 p.

Hatcher, R.D., Jr., 1971, Structural, petrologic and stratigraphic evidence favoring a thrust solution to the Brevard problem; Am. Jour. Sci., v. 270, p. 177-202.

Hatcher, R.D., Jr., 1972, Developmental model for the southern Appalachians; Geol. Soc. Am. But1, v. 83, p. 2735-2760.

Hatcher, R.D., Jr., D.E. Howell and C. P. Talwani, 1977, Eastern Piedmont fault system: Speculations on its extent; Geology, v. 5, p. 636-640.

Heffner, J.D., and R.B. Ferguson, Savannah River Laboratory Hydrogeochemical and Stream Sediment Reconnaissance: Preliminary Raw Data Release, Charlotte $1^{\circ} \times 2^{\circ}$ NTMS Area North Carolina and South Carolina; Natural Uranium Resource Evaluation Program GJBX-40(78) Grand Junction, Co., Geologic Map compiled by J.R. Butler, Dept. of Geology, Univ. of North Carolina.

Herrick, S.M. \& H.E. LeGrand, 1949, Geology and Groundwater resources of the Atlanta Area, Georgia; Ga. State Division of Conservation, Dept. of Mines, Mining and Geology; But1.55.

Hopson, C.A., 1964, The crystalline rocks of Howard and Montgomery Counties; in the Geology of Howard and Montgomery Counties; Maryland Geol. Survey, p. 27-275. 
Howe11, D.E., 1976, Major structural features of South Carolina; Geol. Soc. Am. Abs. with Prog., v. 8, p. 200-201.

Hurst, J.V., 1970, The Piedmont in Georgia: in Studies of Appalachian Geology: Central and Southern; ed by G.W. Fisher, F.J. Pettijohn, J.C. Reed, Jr. \& K.N. Weaver; J. Wiley \& Sons, Inc., New York.

Jones, L.M. and R.L. Walker, 1973, Rb-Sr whole-rock age of the Siloam Granite, Georgia: A Permian intrusive in the southern Appalachians; Geol. Soc. Am. Bul1., v. 84 , p. 3653-3658.

Julian, E.L., 1972, The Castalia Adamellite in Franklin and Nash Counties, North Carolina, and the petrogenesis of some associated aplites and pegmatities; M.S. Thesis, North Carolina State Univ., 61 p.

King, P.B., 1955, A geologic section across the southern Appalachians An outline of the geology of the segment in Tennessee, North Carolina and South Carolina; in Guides to southeastern geology ed by R. J. Russel1; Geol. Soc. Amer. Guidebook, p. 332-373.

Odom, A.L., and P.D. Fullagar, 1973, Geochronologic and tectonic relationships between the Inner Piedmont, Brevard Zones, and Blue Ridge belts, North Carolina; Am. Jour. Sci., v. 273-A, Cooper, v. 1, p. 133-149.

Overstreet, W.C. and H. Bell, III, 1965, The crystalline rocks of South Carolina; U.S. Geol. Surv. Bu17. 1183, 126 p.

Overstreet, W.C., 1970, The Piedmont in South Carolina; in Studies of Appalachian Geology: Central and Southern; ed by G.W. Fisher, F. J. Pettijohn, J.C. Reed, Jr., \& K.N. Weaver; J. Wiley \& Sons, Inc., New York.

Parker, J.M., III, 1968, Structure of Easternmost North Carolina Piedmont; Southeastern Geol., v. 9, p. 117-131.

Rankin, D.W., T.W. Stern, J.C. Reed, Jr., and M.F. Newe11, 1969, Zircon ages of felsic volcanic rocks in the upper Precambrian of the Blue Ridge, Appalachian Mountains; Science, v. 166, p. 741-744.

Reed, J.C., Jr. and B. Bryant, 1964, Evidence for strike-slip faulting along the Brevard zone in North Carolina; Geol. Soc. Am. But1., v. 75, p. $1177-1195$.

Reed, J.C., Jr., et al, 1970, The Brevard Zone: A reinterpretation, in Studies of Appalachian Geology: Central and Southern; ed by G.W. Fisher, F.J. Pettijohn, J.C. Reed, Jr., and K.N. Weaver; J. Wiley \& Sons, Inc., New York. 
Snow, D.T., 1968, Rock fracture spacings, openings and porosities; Soil Mechanics and Foundation Division, ASCE, v. 94, no. SMI.

Stuckey, J.L. \& S.G. Conrad, 1958, Explanatory text for geologic map of North Carol ina; North Carol ina Dept. of Conser. and Deve1., Bul1. 71.

Sundelius, H.W., 1970, The Carolina slate belt, in Studies of Appalachian Geology: Central and Southern; ed by G. W. Fisher, F. J. Pettijohn, J.C. Reed, Jr., \& K.N. Weaver, J. Wiley \& Sons, Inc., New York.

Trask, N.J., et a1, 1977, Lineament map of parts of Virginia, North Carolina, and South Carolina; USGS Open File rep. 77-434.

Uniform Building Code, 1976 ed., Intern. Conf. of Building Officials, Whittier, California.

Wagener, H.D., 1970, Geology of the southern two-thirds of the Winnsboro 15-minute quadrangle, South Carolina; S.C. State Devel. Board, Div. of Geol., MS-17, $34 \mathrm{p}$.

Watson, T.L., 1902, A preliminary report on a part of the granites and gneisses of Georgia; Geological survey of Georgia, Bull. 9-4.

Wilson, W.F., et al. 1976, North Carolina Geology and Mineral Resources: A foundation for progress; North Carolina Dept. of Natural and Economic Resources, Div. of Res. Planning and Eval.

Wise, D.U., 1970, Multiple deformation, geosynclinal transition and the Martic Problem in Pennsylvania, in Studies of Appalachian Geology: Central and Southern; ed by G.W. Fisher, F.J. Pettijohn, J.C. Reed, Jr., \& K.N. Weaver; J. Wiley \& Sons, Inc., New York.

Wright, J.E., A.K. Sinha, and L. Glover, III, 1975, Age of zircons from the Petersburg Granite; Virginia: with comments on belts of plutons in the Piedmont; Am. Jour. Sci., v. 275, p. 848-856. 
TABLES 


\section{TABLE 1}

\section{MODIFIED MERCALLI (MM) EARTHQUAKE INTENSITY SCALE (abridged)}

I. Not felt except by a very few under especially favorable circumstances.

I1. Felt only by a few persons at rest, especially on upper floors of buildings. Suspended objects may swing.

III. Felt quite noticeably indoors, especially on upper floors of buildings. Standing motor cars may rock slightly.

IV. During, the day felt indoors by many, outdoors by few. At night some awakened. Dishes, windows, doors disturbed. Standing motor cars rocked noticeably.

V. Felt by nearly everyone, many awakened. Some dishes, windows, etc., broken; unstable objects overturned. PenduTum clocks may stop.

VI. Felt by all; many frightened and run outdoors.

VII. Everybody runs outdoors. Damage negligible in buildings of good design and construction. Shock noticed by persons driving motor cars.

VIII. Damage slight in specially designed structures; considerable in ordinary substantial buildings; great in poorly built structures. Fall of chimneys, stacks, columns. Persons driving motor cars disturbed.

IX. Damage considerable even in specially designed structures; we 11-designed frame structures thrown out of plumb. Buildings shift off foundations. Ground cracked conspicuously.

$x$. Some well-built wooden structures destroyed; ground badly cracked; rails bent. Landslides and shifting of sand and mud.

$X I$. Few if any (masonry) structures remain standing. Broad fissures in ground.

XII. Damage total. Waves seen on ground surface. 
TABLE 2

EARTHQUAKE INTENSITIES OF $\vee$ AND GREATER - SOUTHEAST UNITED STATES

$\begin{array}{cc}\text { No. } & \text { Year } \\ & \\ 1 & 1758 \\ 2 & 1774 \\ 3 & 1827 \\ 4 & 1844 \\ 5 & 1852 \\ 6 & 1855 \\ 7 & 1857 \\ 8 & 1871 \\ 9 & 1872 \\ 10 & 1874 \\ 11 & 1874 \\ 12 & 1875 \\ 13 & 1875 \\ 14 & 1875 \\ 15 & 1877 \\ 16 & 1879 \\ 17 & 1879 \\ 18 & 1882 \\ 19 & 1883 \\ 20 & 1883 \\ 21 & 1884 \\ 22 & 1884 \\ 23 & 1885 \\ 24 & 1885 \\ 25 & 1885 \\ 26 & 1886 \\ 27 & 1886 \\ 28 & 1886 \\ 29 & 1886 \\ 30 & 1889 \\ 31 & 1897 \\ 32 & 1897 \\ 33 & 1897 \\ 34 & 1897 \\ 35 & 1898\end{array}$

\section{Month \\ Day}

04

02

08

11

02

12
10

06

02

04

06

11

12

11

03

12

02

03

03

01

09

01

08

10

09

10

10

11

03

05

05

10

12

02
25

21
07

28

29

02
19

19
09

17

10

17

18

02

23

16

26

13

09

11

12

18

19

03

06

10

01

22

22

05

08

03

31

22

18

05
Lat.

$38.900 \mathrm{~N}$

$37.200 \mathrm{~N}$
$38.300 \mathrm{~N}$

$36.000 \mathrm{~N}$

$36.600 \mathrm{~N}$

$37.000 \mathrm{~N}$

$32.900 \mathrm{~N}$

$39.700 \mathrm{~N}$

$33.100 \mathrm{~N}$

$35.700 \mathrm{~N}$

$35.700 \mathrm{~N}$

$40.200 \mathrm{~N}$

$33.800 \mathrm{~N}$

$37.600 \mathrm{~N}$

$35.500 \mathrm{~N}$

$39.200 \mathrm{~N}$

$35.200 \mathrm{~N}$

$40.600 \mathrm{~N}$

$39.500 \mathrm{~N}$

$39.500 \mathrm{~N}$

$34.300 \mathrm{~N}$

$40.700 \mathrm{~N}$

$39.200 \mathrm{~N}$

$36.200 \mathrm{~N}$

$37.700 \mathrm{~N}$

$32.900 \mathrm{~N}$

$32.900 \mathrm{~N}$

$32.900 \mathrm{~N}$

$32.900 \mathrm{~N}$

$40.000 \mathrm{~N}$

$37.100 \mathrm{~N}$

$37.300 \mathrm{~N}$

$37.000 \mathrm{~N}$

$37.700 \mathrm{~N}$

$37.000 \mathrm{~N}$
Long.

$076.500 \mathrm{~W}$

$077.400 \mathrm{~W}$

$085.800 \mathrm{~W}$

$084.000 \mathrm{~W}$

$081.600 \mathrm{~W}$

$078.600 \mathrm{~W}$

$080.000 \mathrm{~W}$

$075.500 \mathrm{~W}$

$083.300 \mathrm{~W}$

$082.100 \mathrm{~W}$

$082.100 \mathrm{~W}$

$084.000 \mathrm{~W}$

$082.500 \mathrm{~W}$

$078.500 \mathrm{~W}$

$084.000 \mathrm{~W}$

$075.500 \mathrm{~W}$

$080.800 \mathrm{~W}$

$084.200 \mathrm{~W}$

$076.400 \mathrm{~W}$

$076.400 \mathrm{~W}$

$078.000 \mathrm{~W}$

$084.100 \mathrm{~W}$

$077.500 \mathrm{~W}$

$081.600 \mathrm{~W}$

$078.800 \mathrm{~W}$

$080.000 \mathrm{~W}$

$080.000 \mathrm{~W}$

$080.000 \mathrm{~W}$

$080.000 \mathrm{~W}$

$076.000 \mathrm{~W}$

$080.700 \mathrm{~W}$

$080.700 \mathrm{~W}$

$087.000 \mathrm{~W}$

$077.500 \mathrm{~W}$

$080.700 \mathrm{~W}$
Epicenter

Intensity (MM)

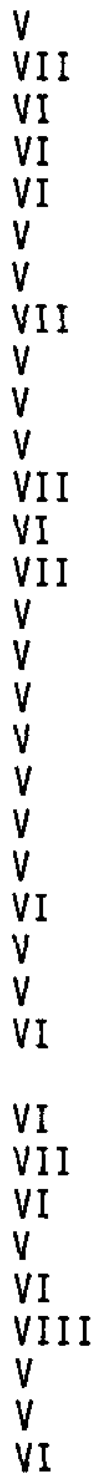


TABLE 2 (Cont'd)

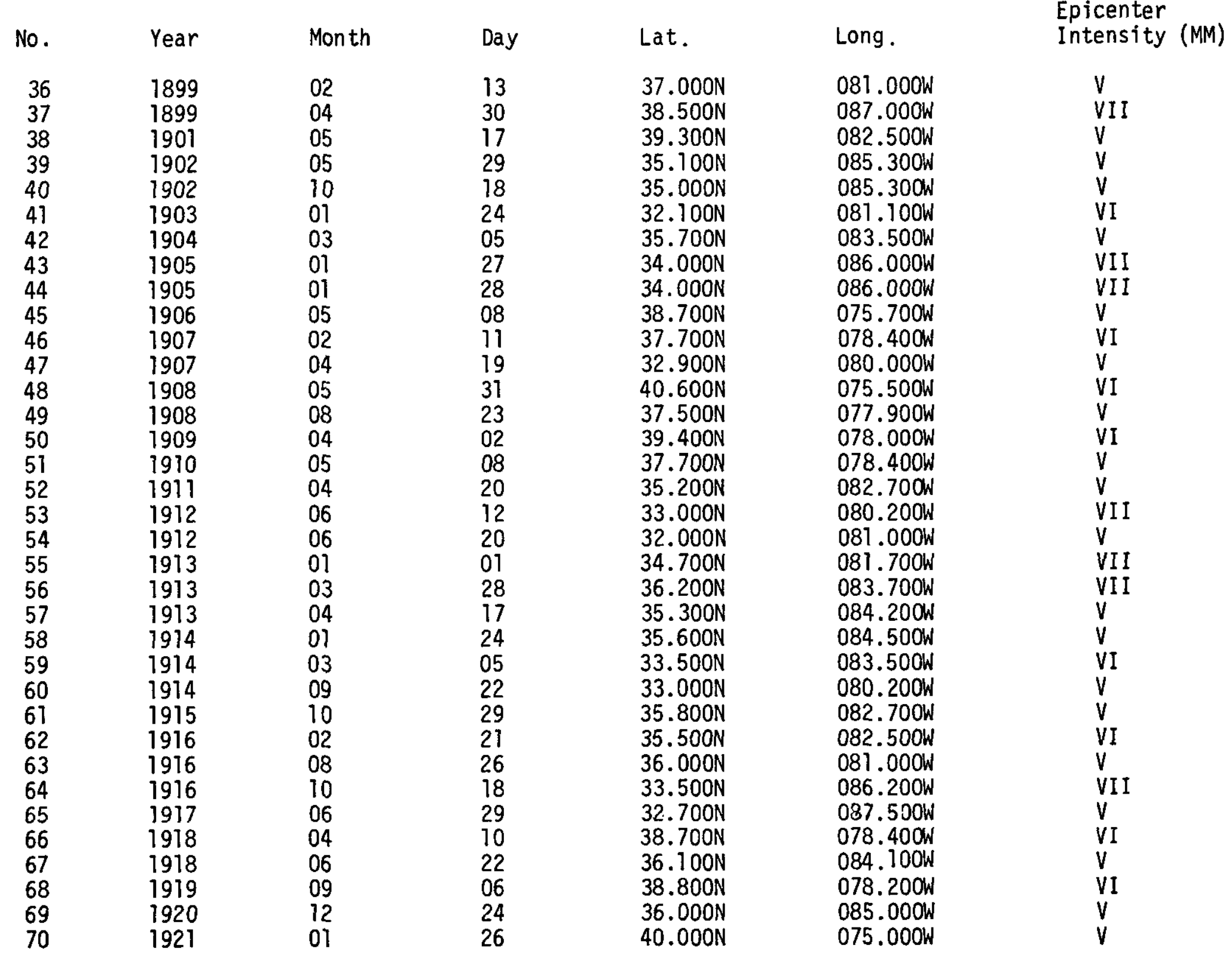


TABLE 2 (Cont'd)

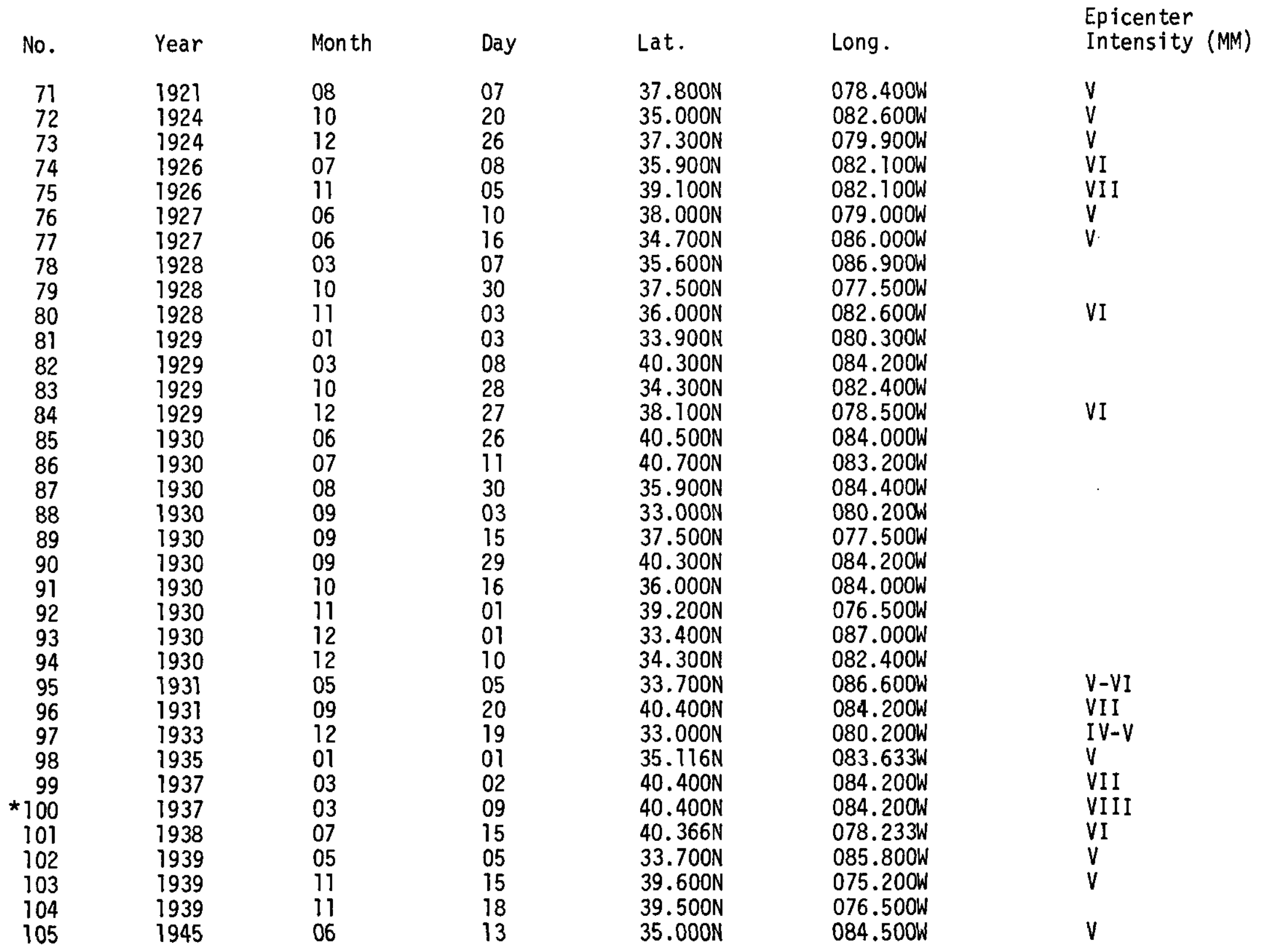

*Instrumentally Located 
TABLE 2 (Cont'd)

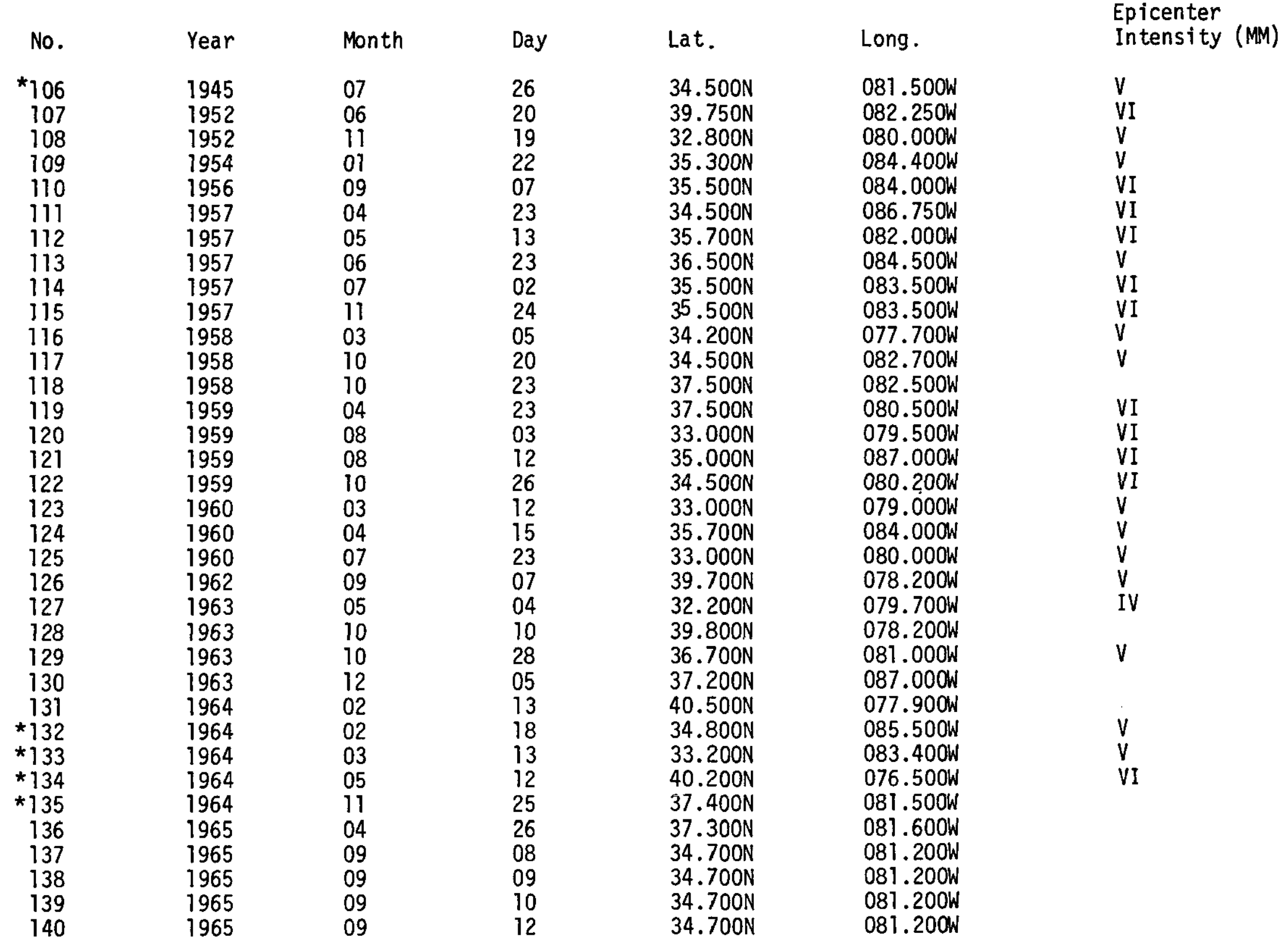

*Instrumentally Located 
TABLE 2 (Cont'd)

\begin{tabular}{|c|c|c|c|c|c|c|}
\hline No. & Year & Month & Day & Lat. & Long. & $\begin{array}{l}\text { Epicenter } \\
\text { Intensity (MM) }\end{array}$ \\
\hline $\begin{array}{r}* 141 \\
\star 142 \\
\star 143 \\
\star 144 \\
\star 145 \\
* 146 \\
147 \\
148 \\
* 149 \\
150 \\
151 \\
152 \\
* 153 \\
* 154 \\
155 \\
156 \\
157 \\
158 \\
159 \\
160 \\
* 161 \\
162 \\
163 \\
\star 164 \\
165 \\
* 166 \\
167 \\
168 \\
* 169 \\
* 170 \\
* 171 \\
172 \\
\star 173 \\
\star 174 \\
\star 175\end{array}$ & $\begin{array}{l}1966 \\
1967 \\
1967 \\
1967 \\
1968 \\
1968 \\
1969 \\
1969 \\
1969 \\
1969 \\
1969 \\
1970 \\
1970 \\
1970 \\
1970 \\
1970 \\
1971 \\
1971 \\
1971 \\
1971 \\
1971 \\
1971 \\
1971 \\
1971 \\
1972 \\
1972 \\
1972 \\
1972 \\
1973 \\
1973 \\
1973 \\
1973 \\
1974 \\
1974 \\
1974\end{array}$ & $\begin{array}{l}05 \\
04 \\
10 \\
12 \\
03 \\
09 \\
05 \\
11 \\
11 \\
12 \\
12 \\
05 \\
07 \\
07 \\
08 \\
09 \\
02 \\
02 \\
03 \\
04 \\
05 \\
07 \\
09 \\
10 \\
01 \\
02 \\
05 \\
12 \\
02 \\
10 \\
11 \\
12 \\
03 \\
04 \\
05\end{array}$ & $\begin{array}{l}31 \\
08 \\
23 \\
16 \\
08 \\
22 \\
22 \\
19 \\
20 \\
11 \\
13 \\
27 \\
30 \\
30 \\
11 \\
10 \\
18 \\
19 \\
05 \\
01 \\
19 \\
31 \\
12 \\
09 \\
09 \\
03 \\
20 \\
08 \\
28 \\
30 \\
30 \\
19 \\
23 \\
27 \\
30\end{array}$ & $\begin{array}{l}37.600 \mathrm{~N} \\
39.555 \mathrm{~N} \\
33.400 \mathrm{~N} \\
37.400 \mathrm{~N} \\
37.280 \mathrm{~N} \\
34.000 \mathrm{~N} \\
39.694 \mathrm{~N} \\
37.400 \mathrm{~N} \\
37.400 \mathrm{~N} \\
37.800 \mathrm{~N} \\
35.100 \mathrm{~N} \\
39.650 \mathrm{~N} \\
37.012 \mathrm{~N} \\
37.012 \mathrm{~N} \\
38.400 \mathrm{~N} \\
36.100 \mathrm{~N} \\
39.662 \mathrm{~N} \\
37.128 \mathrm{~N} \\
40.623 \mathrm{~N} \\
37.365 \mathrm{~N} \\
33.339 \mathrm{~N} \\
33.370 \mathrm{~N} \\
38.073 \mathrm{~N} \\
35.862 \mathrm{~N} \\
37.357 \mathrm{~N} \\
33.476 \mathrm{~N} \\
37.014 \mathrm{~N} \\
40.145 \mathrm{~N} \\
39.718 \mathrm{~N} \\
35.750 \mathrm{~N} \\
35.799 \mathrm{~N} \\
32.983 \mathrm{~N} \\
38.917 \mathrm{~N} \\
41.004 \mathrm{~N} \\
37.382 \mathrm{~N}\end{array}$ & $\begin{array}{l}078.000 \mathrm{~W} \\
082.489 \mathrm{~W} \\
080.700 \mathrm{~W} \\
081.600 \mathrm{~W} \\
080.840 \mathrm{~W} \\
081.500 \mathrm{~W} \\
078.192 \mathrm{~W} \\
081.000 \mathrm{~W} \\
081.000 \mathrm{~W} \\
077.400 \mathrm{~W} \\
083.000 \mathrm{~W} \\
078.157 \mathrm{~W} \\
082.248 \mathrm{~W} \\
082.248 \mathrm{~W} \\
082.300 \mathrm{~W} \\
081.400 \mathrm{~W} \\
078.212 \mathrm{~W} \\
083.249 \mathrm{~W} \\
078.167 \mathrm{~W} \\
081.629 \mathrm{~W} \\
080.558 \mathrm{~W} \\
080.659 \mathrm{~W} \\
077.444 \mathrm{~W} \\
083.468 \mathrm{~W} \\
081.604 \mathrm{~W} \\
080.434 \mathrm{~W} \\
082.241 \mathrm{~W} \\
076.223 \mathrm{~W} \\
075.441 \mathrm{~W} \\
084.000 \mathrm{~W} \\
083.962 \mathrm{~W} \\
080.260 \mathrm{~W} \\
077.780 \mathrm{~W} \\
075.955 \mathrm{~W} \\
080.419 \mathrm{~W}\end{array}$ & $\begin{array}{l}V \\
\text { I I I } \\
V \\
V \\
V \\
\\
\text { IV } \\
\text { VI } \\
V \\
\text { VI }\end{array}$ \\
\hline
\end{tabular}




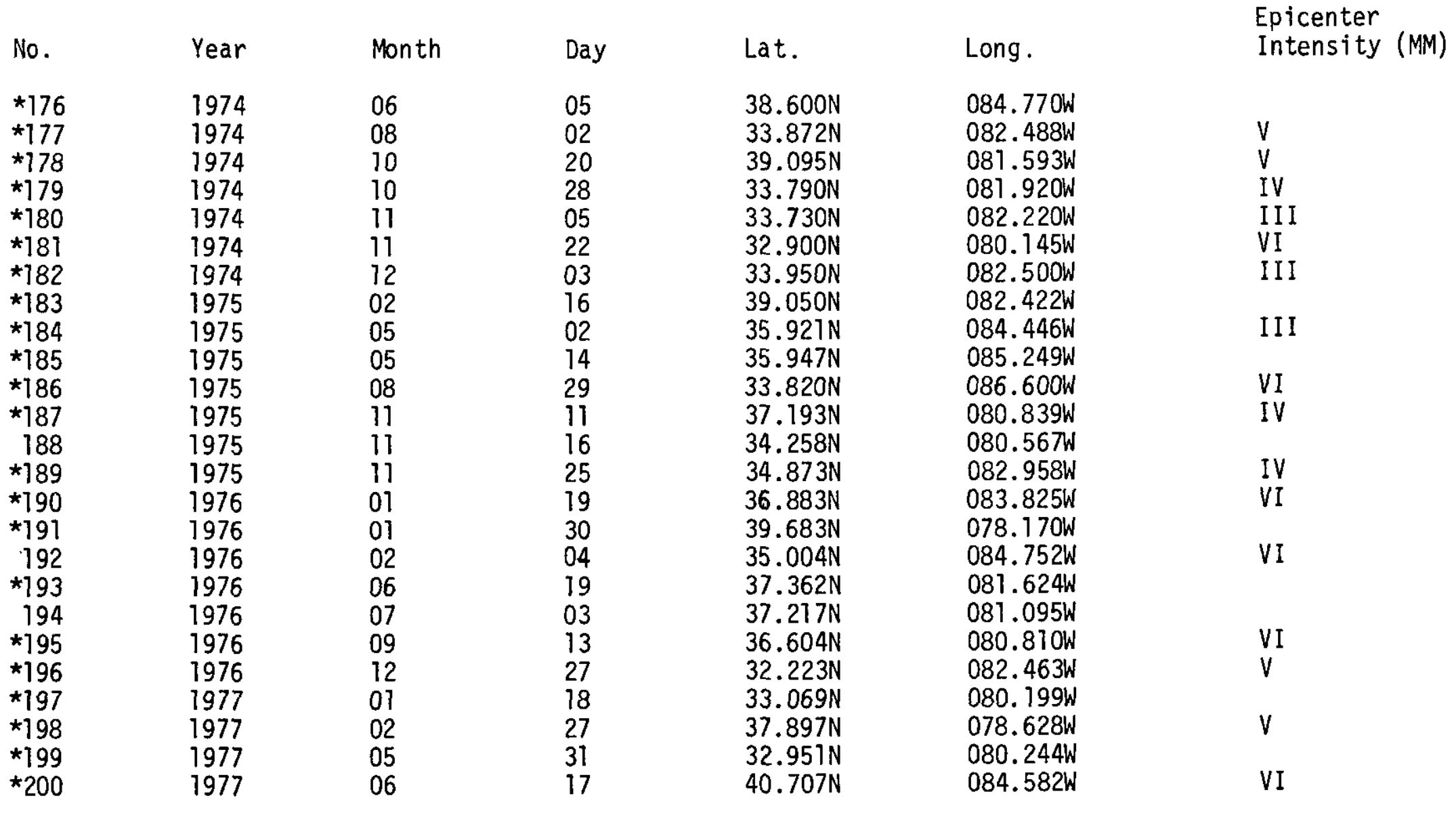

*Instrumentally Located

Data Obtained From:

Earthquake Data Center

U.S. Department of Commerce

National Oceanic and Atmospheric Administration

Boulder, Colorado

Duke Power Company

Preliminary Safety Analysis Report - Catawba Station

(Docket \#50-413) 
TABLE 3

PHYSICAL AND MECHANICAL ROCK PROPERTIES

(a) Physical and Mechanical Properties and Conditions

Desirable Range

(1) Compressive Strength

Medium to very high*

(2) Modulus of Elasticity

Medium to high*

(3) Rock Quality

Good to excellent**

(4) Rock Material Strength

Strong to very strong*

(5) Joint Spacing

Wide to very wide**

(6) In-situ Stresses

Very low to low tectonic residual stresses at 300 to $1200 \mathrm{~m}(1,000-4,000$ feet $)$ depths, respectively*** (Horizontal stresses up to 1.5 times the vertical stresses).

* Related to stability of underground chamber.

** Related to permeability, stability and support requirements of underground chamber. Should require minimal support to eliminate long-term dependence on artificial support systems.

*** Related to post-mining stress level which must be less than the strength of the rock for stability of chamber.

(a) Refer to Appendix A for more details of desirable ranges. 
TABLE 4_SHEET 3. OF 5

GEOLOGICAL REVIEW OF ROCK UNITS -

PIEDMONT PROVINCE

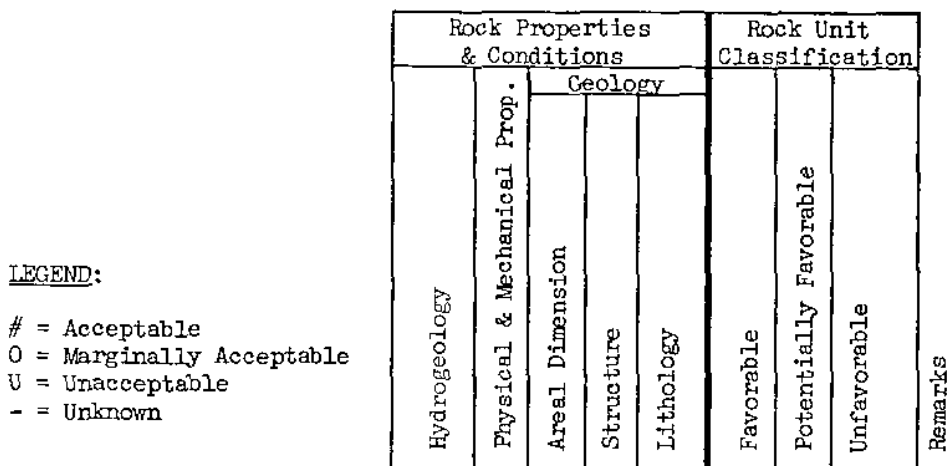

SYMBOL FORMATIONS

IGNEOUS PLUTONIC ROCKS

Pzp

Pzg

Pze

PEW

gm

$\mathrm{bgb}$

Baltinore Gabbro Complex

\section{METAMORPHIC ROCKS}

Pzod

Port Deposit Gneiss

Gunpowder Granite

\section{AGE AND DFSCRTPTION}

Paleo.: Quartz-Albite-mierocline-perthite muscovite granite pegmatites associated with gneiss domes

Paleo.: Biotite-muscovite-quartz monzonite; occurs as discontinuous lenticular bodies

Paleo.: Ranges from biotite granodiorite along margin of body to quartz monzonite in core

Paleo.: Massive biotite-quartz monzonite

Late Paleo. to Late Precamb.: Poorly exposed complex of tonalite, quartz diorite, gabbro, amphibolite, and undifferentiated basic rock

Eaxly Paleo, to Late Precamb.: Hypersthene gabbro with subordinate amount of olivine gabbro, norite, anorthositic gabbro and pyroxenite; slightly to

Paleo.: Moderately to strongly deformed intrusire complex composed of gneissic biotite-quartz diorite, cmplex conpos of greissio biotite-quarta diorite, cranodiorite; all rocks foliated and some strongly sheared

Paleo.: Remobilized Baltimore gneiss; quartz monzonite with biotite schlieren

|

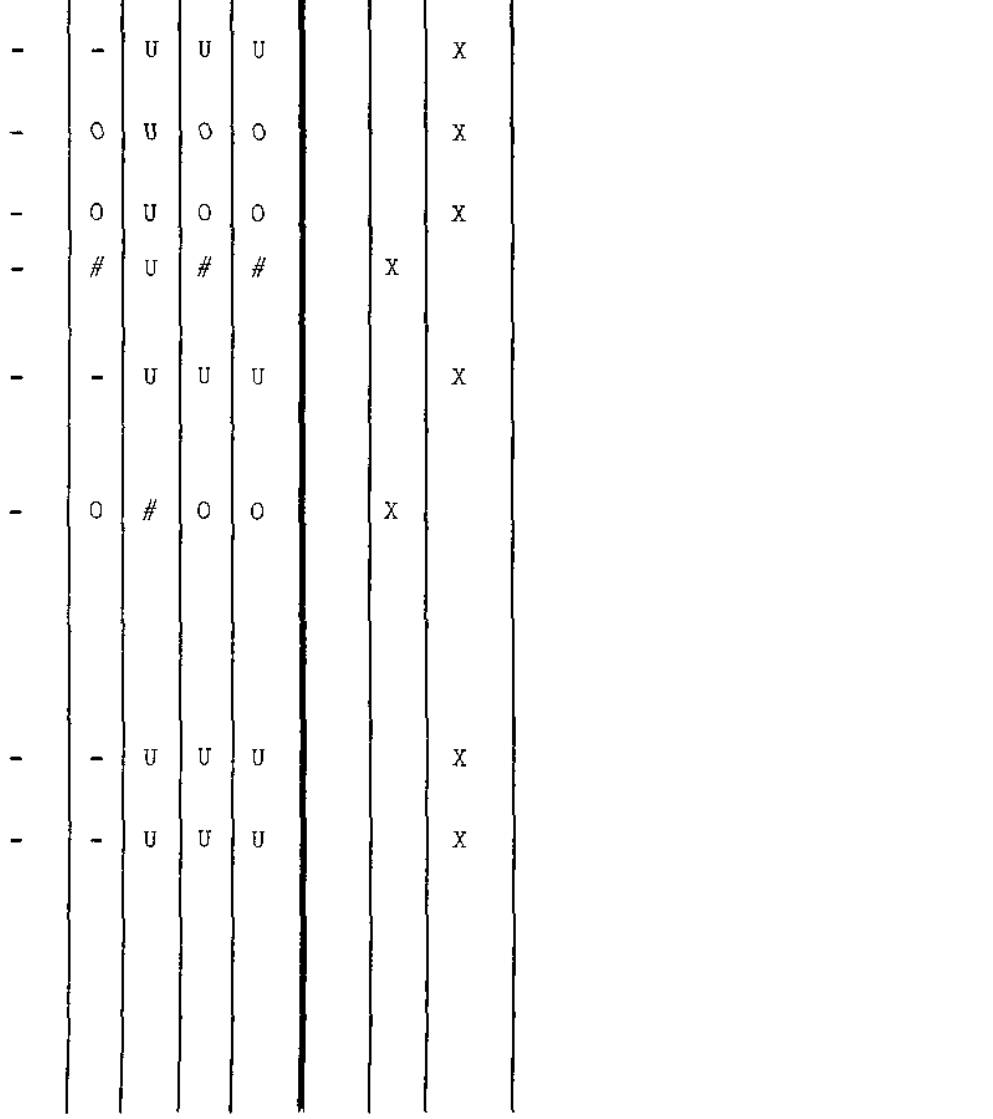


TABLE 4 SHEET 2 OF 5

GEOLOGICAL REVIEW OF ROCK UNITS -

PIEDNONT PROVINCE

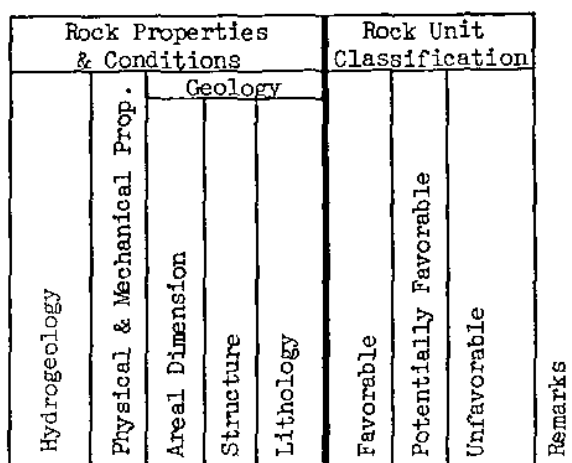

\section{SIMBOL FORMATIONS}

METAMORPHIC BOCKS (Cont'd)

Pzgd

Pan

Pzk

Pzmg
Quartz Cabbro and Quartz

Diorite Gneiss

Norbeck Quartz Diorite

Kensington Quartz Diorite

Muscovite Quartz Monzonite Gneiss

Ultramafic Rocks

U1tramafic and Gabbroic Rocks

Ketagabbro and Amphibolite

Urbana Formation

\section{LEGEND:}

$\#=$ Acceptable

= Marg Inally Acceptable

= Unacceptabl

$=$ Unknown

AGE AND DESCRIPTION

Paleo.: Mixed rock zone of uralitized, quartz bearing gabbro to weakIy gneissic pyroxene-homblende-biotite quartz diorite

Paleo.: Ranges from weakly foliated quartz diorite to strongly gneissic and schistose rock with recrystallized textures

Paleo.: Moderately to strongly deformed; igneous textures generally destroyed; ranges from quartz diorite to granodiorite; comprises thin concordant sheets or wedges along plunging crest of Baltimore anticlinoriutn

Paleo.: Well foliated to nearly massive quartz monzonite gneiss; generally even textured but locally porphyritic

Early Paleo. to Late Precano.: Chierly serpentinite with partly to completely altered dunite, peridotite, pyroxinite, and massive to schistose soapstone;talecarbonate rock and altered gabbro are common

arly Paleo.: Mixed metagabbro, serpentinite, metapyroxinite, and actinolite-, chlorite-, an epidote-bearing schists

Early Paleo.: Weakly to strongly lineated metagabbro and epidote amphibolite

Late Precamb.: Sericite-chlorite phyllite, metasiltstone, and quartaite; thin lenses of impure siltstone, and quartzite; thin lenses of impure

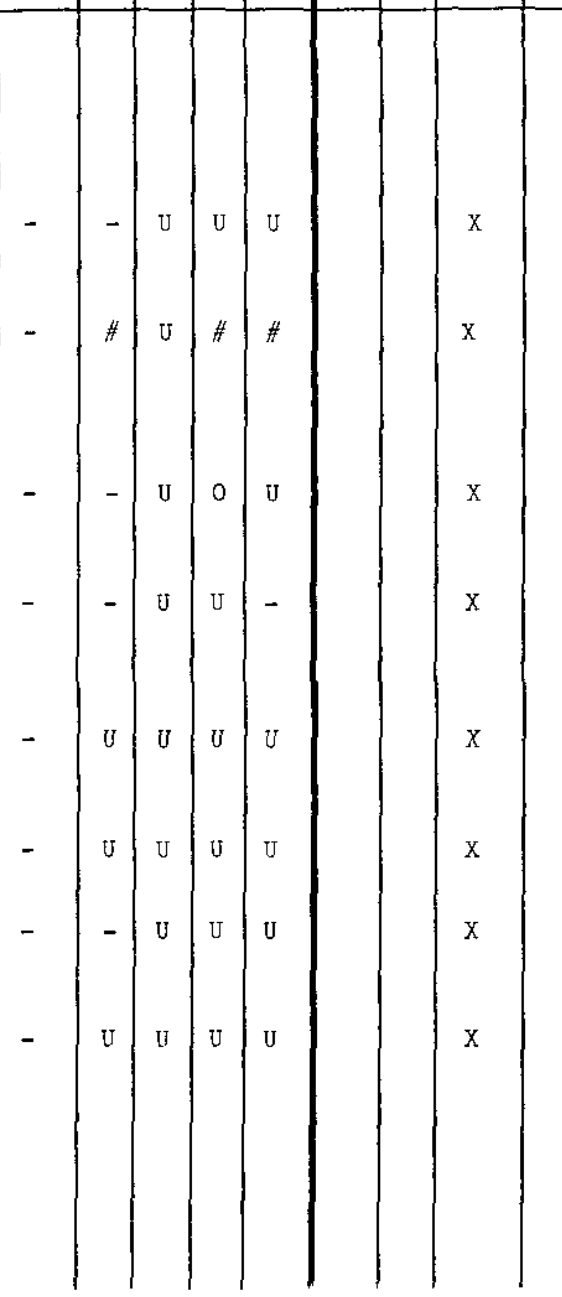


TABLE_4_ SHEET 3 OF 5

GEOLOGICAL REVIEW OF ROCK UNITS -

$\begin{array}{ll}\#=\text { Acceptable } & 0=\text { Marginally Acceptable } \\ & \text { U = Unacceptable } \\ & -=\text { Unknown }\end{array}$

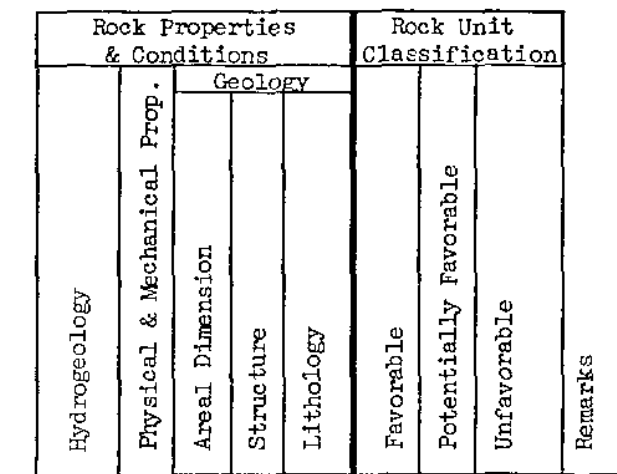

SYMBOL FORMATIONS

METAMDRPHIC ROCKS (Con:'d )

sq

wm

Sugarloaf Mountain

Quartzite

Wakefield Marble

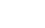

Ijamsville Formation

wr
Marburg Schist

Wissahickon Formation (undivided)

Upper Pelitic Schist (Wissahickon Fm)

Metagraywacke

(Wissahickon Fm)

Sykesville Boulder Gneiss (Wissahickon $\mathrm{Fm}$ )

Lower Pelitic Schist (Wissahickon $\mathrm{Fm}$ )

Cockeysville Marble

\section{AGE AND DESCRIPTION}

Late Precamb.: Massive quartzite interbedded with softer sericitic quartzite, slate, and phyllite Late Precamb.: Marble

Late Precamb.: Phyllite and phyllitic slate, with interbedded metasiltstones and metagraywackes; pumaceous blebs loca1ly

Late Precamb,: Mhuscovite -chlorite-albite-quart (nist; intensely cleaved and closely folded; contain interbedded quartzites

Late Precamb.: Muscovite-chlorite-albite schists, muscovite-chlorite schist, chloritoid schist, and quartzite, intensely folded and cleaved

Late Precamb.: Albite-chlorite-muscovite-quartz schist with sporadic thin beds of laminated micaceous quartzite

Late Precamb.: Rhythrically interbedded chloritemascovite graywacke and chiorite-muscovite schist

Late Precamb.: Thick bedded to massive, pebble and rock; typically a garnet-oligoclasc-mica-quartz gneiso;

Late Precanb.: Biotite-oligoclase-muscovite-quartz schist with garnet, staurolite, and kyanite; some semipelitic schist and weakly schistose psamitic granulite

Late Precamb.: Metadolomite, calc-schist, and calcite marble are predominent; gneiss and calc-silicate marble widespread but minor

-


TABLE 4 SHEET 4 OF 5

GEOLOOICAL REVIEW OF FOCK UNITS -

MARYILAND

PIEDMDNT PROVINGE

\section{LEGEND:}

$A=$ Acceptable

= Marginally Acceptable

$\mathrm{U}=$ Unacceptabl

- = Unknown
SYMBOL

FORMATIONS

METAMORPHIC ROCKS (Cont'd)

Setters Formation

pEbq

Baltimore Gneiss

sem

Sams Creek MetabasaIt

$1 \mathrm{mr}$

Libertytom Metarhyolite

\section{SEDIMENTAFY ROCKS}

srl

Silver Run Limestone

$\epsilon f$

Frederick Iimestone

$\propto g$

Grove Limestone

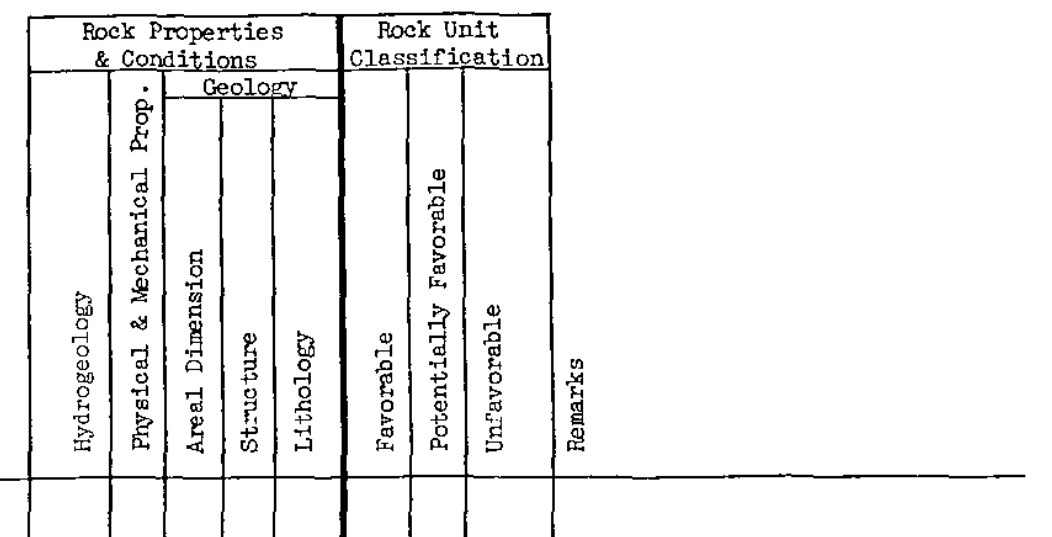

AGE AND DESCRIPTION

Late Precamb.: Upper member: Feldspathic mica schist and mica gneiss; Middle member: Impure schist; Iower member: Feldspathic mica schist; locally granitized

Precamb.: Biotite-quartz-feldspar gneiss and biotitehormblende gneiss; anphibole widespread but subordinate; texturaliy varied; granite gneiss, veined

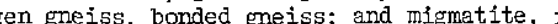
places complexly intermingled

Late Precamb.: Massive to sehistose, arygdaloidal metabasalt

Late Precamb.: Metarhyolite with feldspar phenocrysts interbedded amygdaloidal meta-andesite; both rhyolite and andesite interbedded with phyllitic lates

Late Precamb.: Thin bedded, finely crystalline schistose limestone and calcareous slate

Camb,: Slabby, thin bedded linestone and minor shale Camb. to Ord.: Thick bedded limestone; dolomite beds in lower part; highly quartzose at base 
TABLE 4 SHEET 5 OF 5

GEOLOGICAL REVIEW OF ROCK UNITS -

PTEDTONT PROVINCE

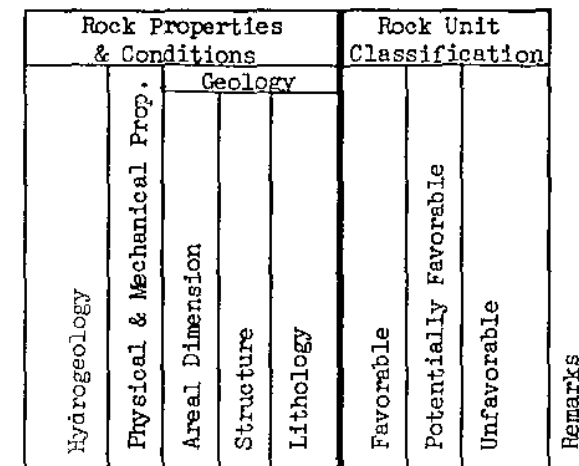

STMBOL FORMATIONS AGE AND DESCRIPTION

VOLCANIC BOCKS

Volcanic Complex of Cecil County

Quaternary Ailluvium

OTHER ROCKS

Qa]

的

Fio

㼛

政

Kp
Triassic Dikes and Sills-Diabase

New Oxford Formation

(Sandstones, siltstone, etc.)

Gettysiburg Shale

New Oxford Formalition

(Quartzite)

Potomac Group

(Coastal Plain)
$\#$ = Acceptable

$0=$ Marginally Acceptable

$v==$ Marginally Acce

- = Unknown

AGE AND DESCRIPTION

Late Precamb.: Metamorphosed andesitic and dacitic volcanic rocks (greenstone, greenschist, quartz amphibolite, and schistose felsite), anygdules and volcano-clastic textures locally preserved

Not included in thìs study

Not included in this study

Triassic - not included in this study

Traissic - not included in this study

Triassic - not included in this study

Not included in this study

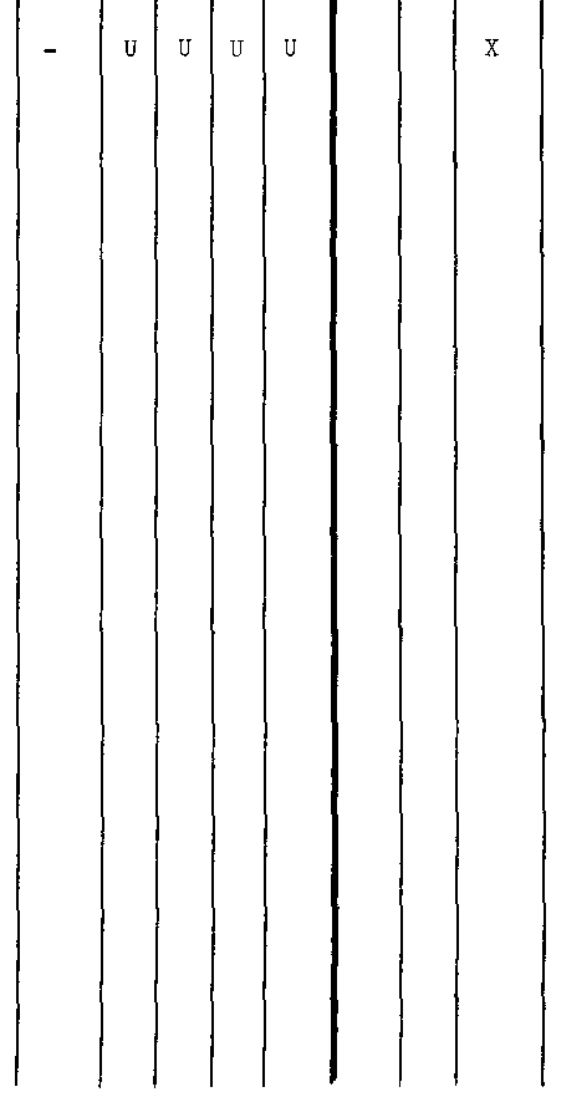




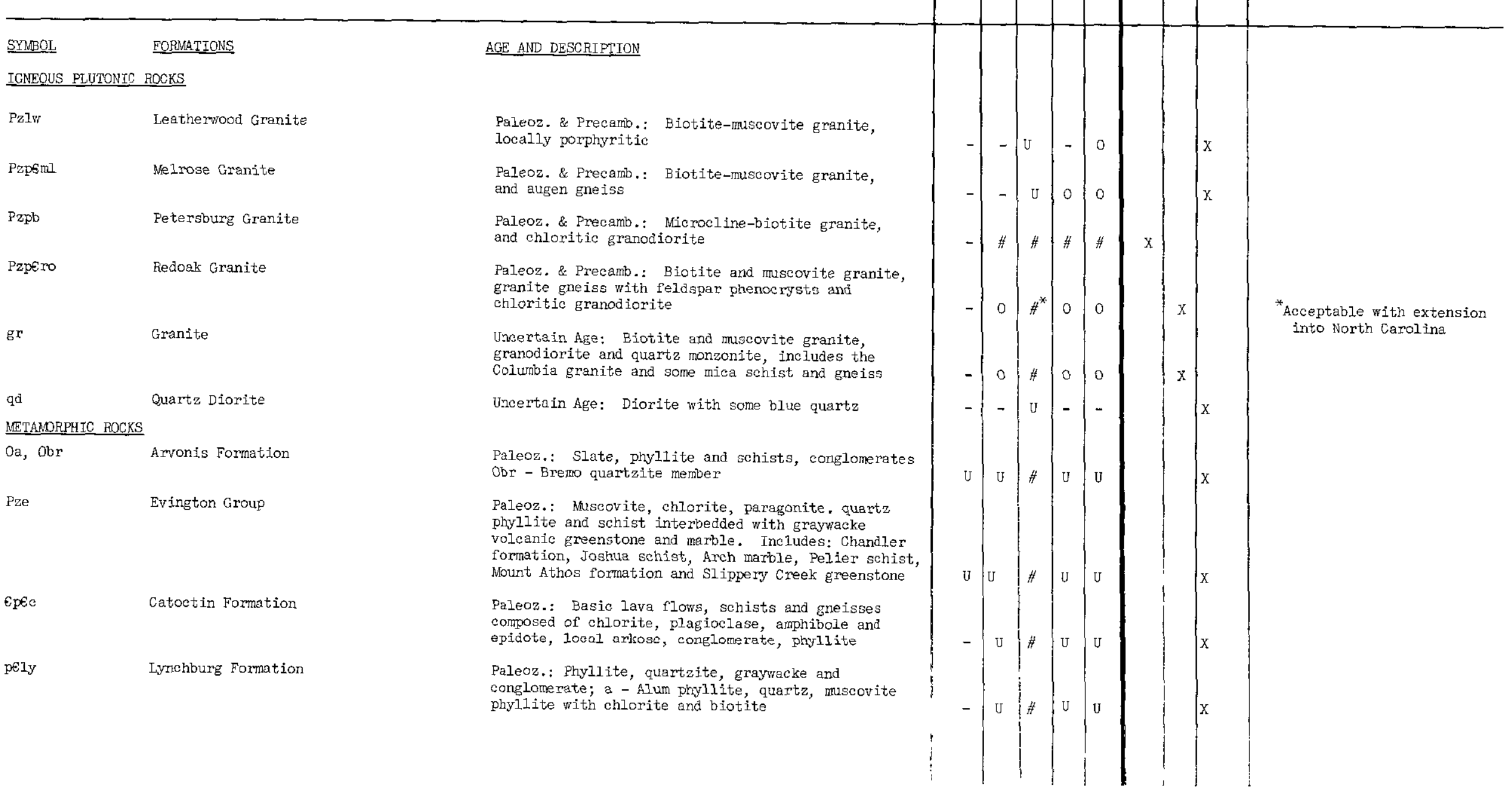


TABLE 5 SHEET 2 OF 3

GEOLOGIC REVIEW OF ROCK UNITS -

PIEDMONT PROVINCE

\section{SYMBOL FORMATIONS}

METAMORPHIC ROCKS

Pzpest

Shelton Granite Gneiss

am

Amphibolite

grgn

Granite Gneiss

ghgn

Granite and Hormblende Gneiss

hgb

Homblende Gabbro and Gneiss; Tal

$\mathrm{m}\left[\begin{array}{l}\mathrm{mgn} \\ \mathrm{mp} \\ \mathrm{msch}\end{array}\right.$

Netamorphosed Sedimentary Rocks

\section{SEDINANTARY ROCKS}

Im

Limestone and Narble

(Metamorphic)
= Acceptable

= Marginally Acceptable

$=$ Inacceptable

- = Unknown

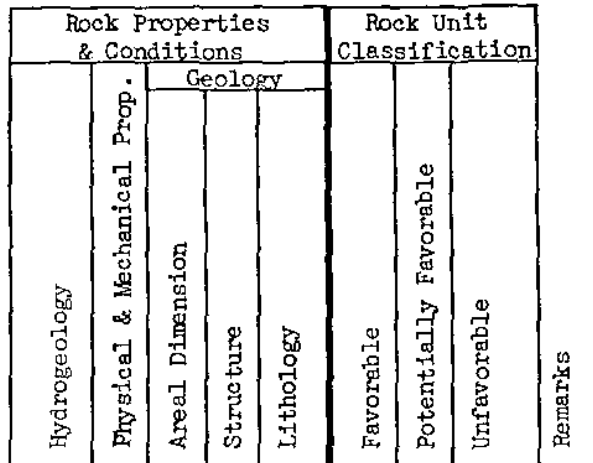

AGE AND DESCRIPTION

Paleoz. \& Precamb.: Granite gneiss, augen gneiss and mylonite

Uneert.: Amphibolite and amphibole rich foliates

Uncert.: Biotite and muscovite granite gneiss

Uncert.: Interlayered mica, quartz, felaspar gneiss and hornblende, feldspar, mica gneiss

Uncert.: Amphibole-chlorite schist, chloritic homblende gneiss; and some amphibolite, chloritic diorite, and hormblende diorite; and kyanite schist and kyanite quartzite

Uncert.: Includes metamorphosed sedimentary and interlayered igneous rocks that overlie the Virginia Blve Ridge Complex, mp - phyllite; msch - schist and mgn- gneiss; and kyanite schist and kyanite

Uncert.: Includes equivalent of Cockeysville marble in Loundoun and Fauquier Counties, Everona limestone in Central Virginia, limestone and marble in Pittsylvania County 
TABLE 5 SHEET 3 OF 3

GEOLOGICAL REVIEW OF ROCK UNITS VIRGINIA

PIEIMONT PROVINCE

$\begin{array}{ll}\text { STMBOL } & \frac{\text { FORMATIONS }}{\text { IGNEOUS VOLCANIC ROCKS }} \\ \text { PzpEVS } & \text { Virgilina Group } \\ \mathrm{v} & \begin{array}{l}\text { Metamorphosed voleanic and } \\ \text { sedimentary rocks }\end{array} \\ \mathrm{g} & \text { Greenstone Volcanics }\end{array}$

\section{COASTAL PLAIN SEDIMENTS}

Tu, Tc, Ta, Kpt,

TRIASSIC FORMATTONS

Kad

Igneous rocks within Triassic Basin

Kins, ko, hdf

hy, hn $^{2}$
LEGEND:

$\#=$ Acceptable

$0=$ Marginally Acceptable

$=$ Unacceptable

- = Unknown

\section{AGE AND DESCRIPTION}

Paleoz. \& Precamb.: PzpCvg - Altered andesitic flows and tuffs, PzpCvs - Slate, quartz-sericite schist, phyllite and arkose

Uncert.: Extrusive, igneous rocks and interlayered sedimentary rocks. Includes Peters Creek quartzite rom Prince William to Buckingham Counties

Uncert.: Basic lava flows, tuff and slate commonly altered to chlorite bearing rocks

Not included in this study.

Triassie - not ineluded in this study.

Triassic - not included in this study. 
TABLE 6 SHEET 1 OF 2

GEOLOGTCAL REVIEW OF ROCK UNITS NORTH CAROLINA

PIEDMONT PROVINCE

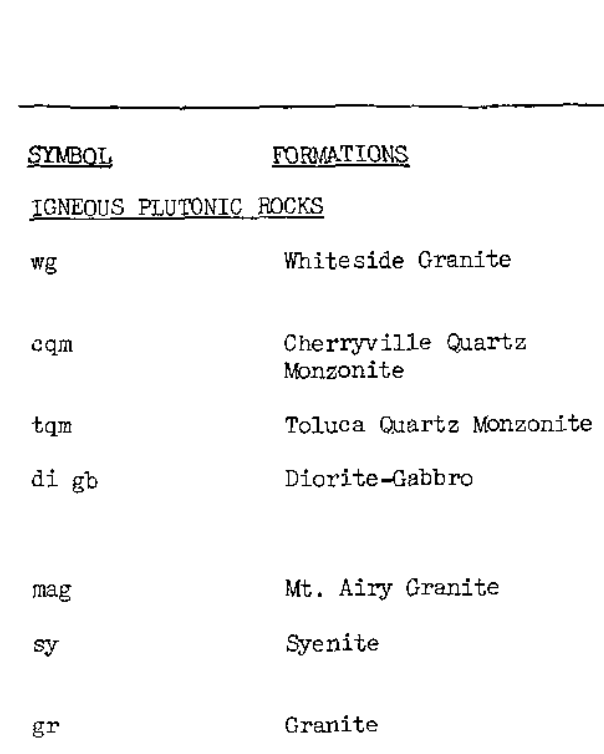

\section{METAMORPHIC ROCKS}

kmg

Kings Mountain Group

hgg

Henderson Granite Gneiss

gne

Granite Gneiss Complex

hgn
LEGEND:

$\#=$ Acceptable

$0=$ Afaringlly Acceptable

$\mathrm{U}=$ Unacceptable

- = Unknown

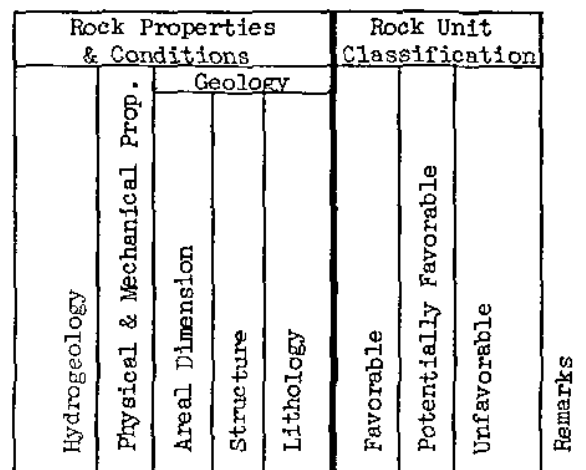

AGE AND DESCRIPTION

Paleoz.: Muscovite-biotite granite, slightly schistose.

Paleoz.: Massive to weakly foliated muscovitebiotite-quartz sonzonite.

Paleoz.: Foliated biotite-quartz monzonite.

Paleoz.(?): Massive to weakly foliated, mostly plagioclase, hormblende and pyroxene, di-diorite predominates, gb-gabbro predominates.

Paleoz.(?): Massive, biotite-quartz monzonite.

Paleoz. (?): Massive to weakly foliated augite syenite.

Paleoz. (?): Massive to weakly foliated, even-grained to porphyritic granitic rocks.

Ir. or Upp. Camb.(?): Quartzite, marble, conglomerate and schist.

Precamb.(?): Granite gneiss, locally augen gneiss, contains lenses of hormblende gneiss, mica gneiss, and mica schist.

Precamb.(?): Contains granite gneiss, mica gneiss, mica schist and hormblende gneiss.

Precamb.(?): Chiefly hormblende gneiss and schist with interbeds of mica gneiss and mice sehist.

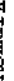

Acceptable with extension into South Carolina

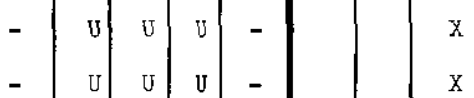

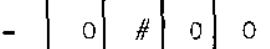

- \# U

- \# U \# \#

$\#$

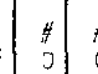

Includes a wide range of granites with variable ranges 
TABLE 6 SHEET 2 OF 2

GEOLOGICAL REVIEW OF POCK UNITS NORTH CAPOLINA PIEDMONT PROVINCE

IDGEND:

$\#=$ Acceptable

Acceptable

$=$ Unacceptable

$=$ Unknown

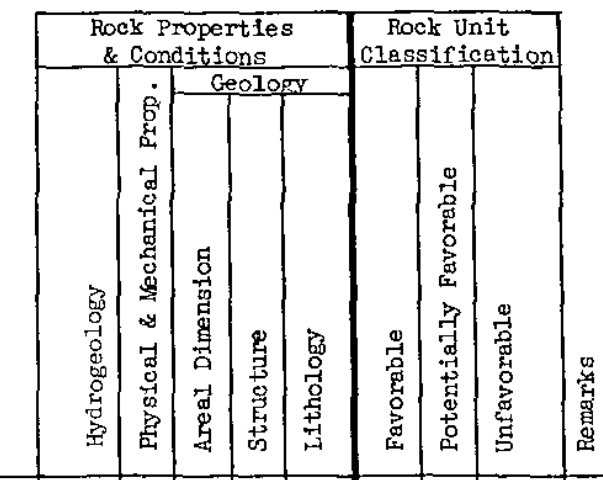

\section{SYMBOL}

FORMATIONS

METAMORPHIC ROCKS (Cont'd)

msh

Mica Sehist

mgn

Mica Gneiss

VOLCANIC ROCKS

ar

mvs

fvs

OTHER ROCKS

Rd

Kt

ku
Diabase Dike

Tuse alcosa Formation

Yorktom Formation

Bedded Argillites (Volcanic slate-Carolina Slate Belt)

Mafic Volcanics

(Carolina SIate BeIt)

Felsic Volcanics

(Carolina Slate Belt)

Undifferentiated Triassic

\section{AGE AND DESCRIPTION}

Precamb.(?): Chiefly mica schist, includes mica Preciss and a wide rarieto of other gneisses and gneiss and
schists.

Precamb.(?): Chiefly mica gneiss, includes mica schist and a wide variety of other gneisses and schists.

Precamb. or Lwr. Paleoz.(?): Bedded volcanic slate, containing lenses of acid and basic fragmentat and flow material.

Precamb. or Lwr. Paleoz.(?): Chiefly basic tuffs, breceias and flows, in part of sedimentary origin also felsic fragmental and flow material and lenses of bedded slate.

Precamb. or Iwr. Paleoz. (?): Chiefly acid tuffs, breccias and flows, in part of sedimentary origin; also mafic fragentals and flow material and lenses of bedded slate; along eastern edge of pledmont lense phyliite.

Not included in this study.

Not included in this study.

Not included in this study.

Not included in this study.

\section{西}


TABLE 7 SHEET 1 OF 4

GEOLOGIC REVIEW OF ROCK UNITS -

LEGEND

$=$ Acceptable

= Marginally Acceptable

$U=$ Unacceptable

- = Unknown

\section{AGE AND DESCRIPTION}

SYMBOL

IGNEOUS PLUTONIC ROCKS

Psy

Pgp

Augite Syenite

Gabbro, Pyroxenite, Norite

Py \& Otm

Yorkille Quartz Monzonite Toluca Quartz Monzonite

POc

Coarse-grained Granite

POr

Fine-grained Granite

POp

$\mathrm{POu}$

Porshyritic Granite

Granite Undivided

MOd

Mafic dike swarms

PMcq

Cherryville Quartz Monzonite

Ogs
Paleo. - Porphyritic, massive, augite syenite

Paleo.- Massive: May be in layered or composite bodies; locally intruded by augite syenite (Psy) syenite pegmatite - composes Ogden Pluton

ord. - Perm.: Porphyritic, massive to gneissic biotite quartz monzonite, Toluca formation is gametiferous

ord. - Perm.: Biotite-juscovite granite, and quarto monzonite; locally porphyritic; locally gneissic; includes porphyritic granodiorite in some are

ord. - Perm.: Massive; biotite granite, biotitemuscovite granite, and quartz monzonite

Ond - Permas Porphyritic biotite-muscorite granite

ord. - Perm.: Massive to gneissic biotite granite and biotite: and biotite-quarta Monechite, grades in composition

Ord. - Miss.: Equigranular to porphyritic, massive to foliated mafic dikes occuring in swarms

principally un-metanorphosed to metamorphosed basalt, andesite, pyroxinite, ard gabbro; local ultramafic rocks biotite-quartz monzonite

Ord.: Massive to foliated hornblende gabbro,

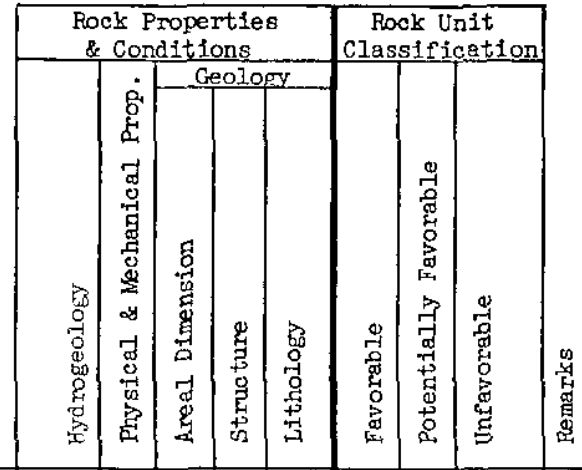

Miss. - Perm.: Massive to weakly foliated muscovitemetapyroxenite, and soafstone; locally intruded by dikes of pegnatite and granite 
TABLE 7 SHEET 2 OF 4

GEOLOGIC REVIEW OF ROCK UNITS -

SOUTH CAROLTNA

PIEDMONT PROVINCE

IEGEND:

$\#=$ Acceptable

Acceptable

= Unacceptabl

- = Unknown

\section{AGE AND DESCRIPTION}

SYMBOL,

FORMATIONS

IGENOUS PLUTONIC ROCKS (Cont'd)

\section{METAMORPHIC ROCKS}

MDs

Mon

MOV S
Sericite Sehist

Homblende Schist

Muscovite Sehist

Quartz-Microcline Gneiss

Anphibolite

Mica Gneiss

Granitoid Gneiss
Ord.: Massive to gneissic oligoclase tonalite; contains angular inclusions of biotite schist in

Ord. - Miss.: Iaminated sericite schist, sericite phylite, quartz-mica schist, biotite schist, biotite gneiss

Ord. - Miss.: Homblende schist, hormblende gneiss, actinolite schist, and chlorite schist, rare layers of marble; closely associated spatially with sericite schist

Ord. - Miss.: Mascovite-biotite-chlorite schist, sericite phylite, includes some intensely sheared rocks, possibly some phyllonite and blastomylonite; cut by numerous quartz veins, locally contains garnet, kyanite and staurolite

Ord. - Miss.: Quartz-microcline gneiss with metacrysts of microcline; interlayered stringers of
hornblende gneiss

Ord. - Miss.: Amphibolite, hormblende schist, homblende gneiss, actinolite schist, and chlorite , biotite

OTd. - Miss.: Layered biotite gneiss, biotite schist, hormblende schist, and hormblende gneiss; granitic

Upper Precamb. and Camb.: Undivided granitoid pher Precante gneisses, gneissic granodiorite, gneissic granite, biotite- 
TABLE 7. SHEET 3 OF 4

GEOLOGIC REVIEW OF ROCK UNITS SOUTH CAROLINA

PIEDMONT PROVINCE

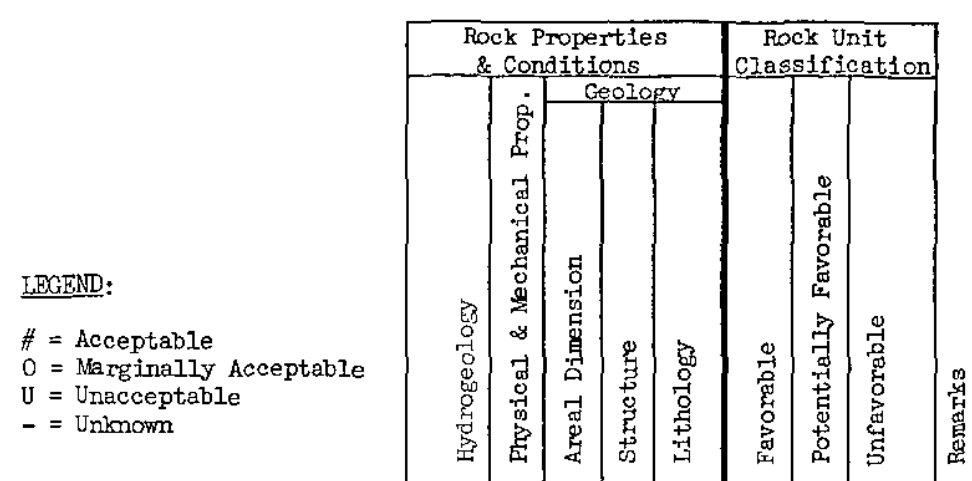

SYMBOLL FORMATIONS

AGE AND DESCRIPTION

\section{METAMORPHIC ROCKS (cont ${ }^{t} \mathrm{~d}$ )}

Doh

Henderson Gneiss

DOgg

Biotite Granite Gneiss

Mgm

Gaffney Maxble

MOiq

Quartzite

MpE s

Biotite Schist

DpEh

Hornblende Gneiss

Biotite Gneiss and Migmatite

MOvu

Argillite
Ord. to Dev.: Porphyritic muscovite-biotite gneiss; locally equigranular and massive

Ord. - Dev.: Biotite granite gneiss

Miss.: Banded to schistose, phlogopite and hormblende bearing marble

Ord. - Miss.: Quartzite, biotite quartzite, and mescovite quartzite: occurs as small thin, lenticular or tabular masses

Upper Precamb. - Miss.: Scaly biotite-oligoclase schist, with thin layer of biotite mejos granitoid, chist, with thin lavers of biotite and homblende schist

Upper Precamb. - Dev.: Hornblende gneiss, homblende schist, amphibolite, and biotite-homblende-oliteclase gneiss: metamomhosed gabbro, diorite, and pyroxenite rare small lenses of soapstone and serpentine; thin discontinuous layers of marble and calc-silicate rocis some interlayered biotite schist, biotite meiss, and granite gneiss

Upper Precamb. - Dev.: Layered, and gametiferous biotite-sillimanite-oligoclase gneiss and biotite oligoclase-quartz gneiss; several strongly banded granitoid layers; thin layers of biotite, sillimanite schist common; local homblende and biotite-homblendeoligoclase gneisses; rare thin layers of quartzite and marble, folded

Ord. - Miss.: Laminated argillite; tuffaceous argillite, and graywacke; includes felsic and mafic agglomerates, breccias, tuffs, and volcanic flows

\begin{tabular}{l|l|l|l|l|l|l|l|l} 
& & & & & & & & \\
\hline
\end{tabular}


TABLE 7 SHEET 4 OF 4

GEOLOGIC REVIEW OF ROCK UNITS -

SOUTH CAROLINA

PIDDONI PROVINCE

\section{SIMBOL}

\section{FORMATIONS}

\section{SEDIMENTARY ROCKS}

Qa1. Quatemary Alluvium

oku

Coastal flain rocks

\section{OTHER ROCKS NOT INCLUDED}

spd

Phyllonite and Blastorylonite

Consolidated Sedimentary Rocks

\section{LEGEND:}

$\#=$ Acceptable

Narginally Acceptable

$=$ Unknown

\section{AGE AND DESCRIPTION}

Not included in this study

Not included in this study

Not incIuded in this study

Not included in this study

Tock Properties

Rock Unit

Conditions

Clessification

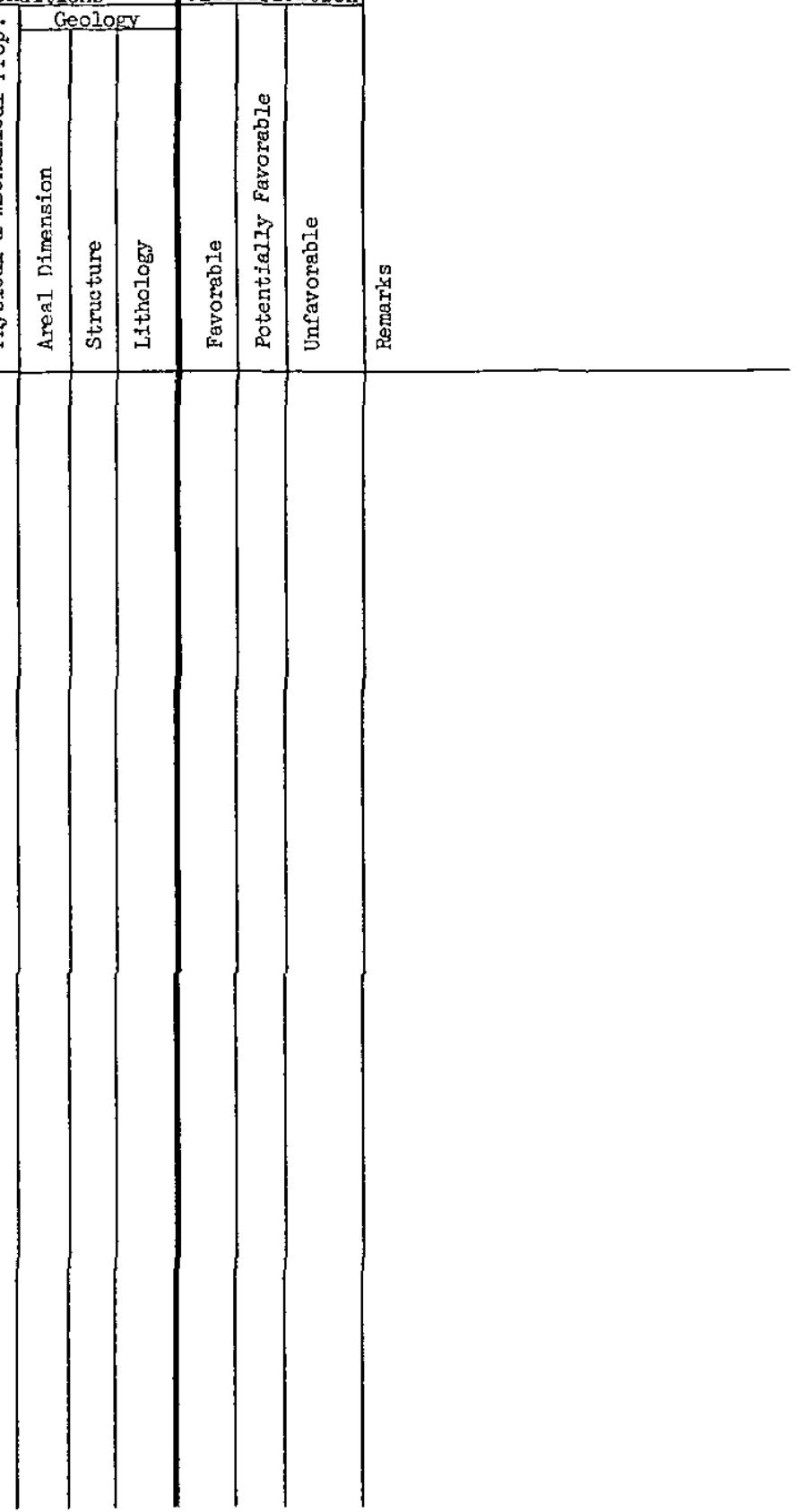


GEOLOCICAL REVIEW OF ROCK UNITS GEORGIA

ONI' PROVINCE

IFGEND:

$\#=$ Acceptable

$0=$ Aarginally Acceptable

= $=$ Unace

$-=$ Unknown
SYMBOL

IGNEOUS PLUTONIC ROCKS

grl, grla, grib

gr2, gr2a

$\operatorname{gr} 4$

mpl, mp2

d

METAMORPHIC ROCKS

ggl, gg3, gg4, gg5, gg6

fg1, fgla, fg2, fg3, fgg

bg1, bg2, bg3, bg4

$\mathrm{mml}, \mathrm{mm} 2, \mathrm{~mm} 3, \mathrm{mn} / \mathrm{m}, \mathrm{mm} 5$,

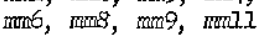

pnsl, pms2, pms3, pms3a, pns4,

pms5, pns6, pms6a, pms6b, pms6c pms6d, pms6e, pms7

ppla

\section{DESCRIPTION}

Granite (Undiff., non-porphyritic, porphyritic)

Granite with gneissic granite

Chamockite

Gabbro/amphibolite

Diabase

Itranafic rock undiff.

Granite gneiss (undiff., muscovite, amphibolite and calc-silicate granite gneiss, granite gneiss/granite)

Gneiss (biotite, biotite-hornblende with amphibolite, undiff, biotite with mica schist-amphibolite, biotite with amphibolite, respectively)

Gneiss (biotite, biotite-amphibolite, biotite-homblende-granite, biotite with mica schist, respectively)

Hormblende gneiss with amphibolite and biotite gneiss, local presence of

Mica schist with amphibolite, gneiss, sericite, schist, sericite phyllite

Meta-argillite, phyllite

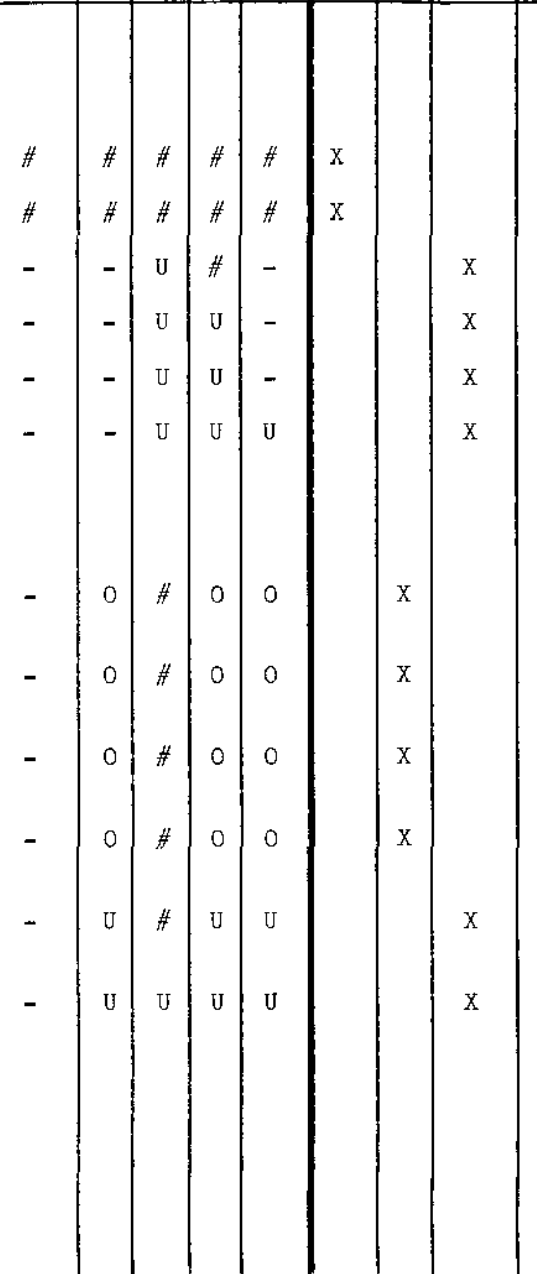


TABIE 8 8 SHEET 2 OF 2

GEOLOGICAL REVIEW OF ROCK UNITS -

\section{SYMBOI}

DESCRIPTION

METAMDRPIC ROCKS (Cont't $\mathrm{d}$ )

pg1, pg2, pg3

pal, pa2, pa2a, pa2b, pa2c

ql, qla, qlb, qle, qld, q2, q3

$\mathrm{cl}, \mathrm{c} 2$

VOLCANIC ROCKS

v1

v2, v3

V4

v5

Garnet-mica schist with gneiss and amphibolite

Sillimanite schist with gneiss and amphibolite

Quartzite with mica schist amphibolite, metagraywacke, phyllite and biotite-garnet gneiss

Mylonite and flinty crush rock respectively

Mafic to intermediate metavolcanic rocks

Netadacite, felsic metavolcanics, respectively

Undiff. metavolcanics/sericite phyllite, meta-argillite, quartz mica schist

Meta-argillite, sericite phyllite and metavolcanics

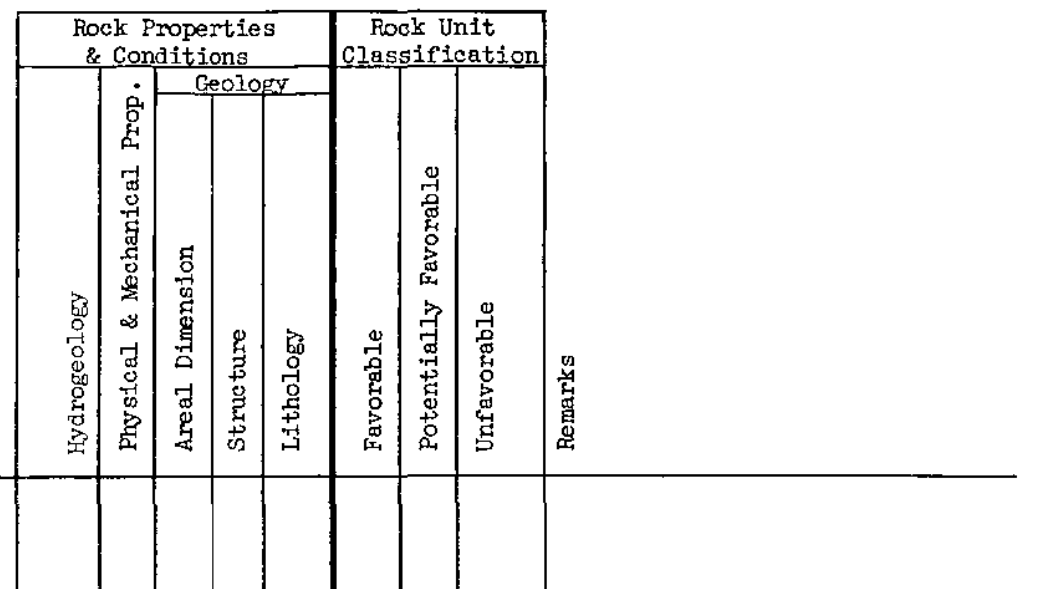

- $\quad$ U

- $\quad$ U U U

$\begin{array}{lllllll}- & \text { U } & \text { U } & \text { U } & \mathrm{U} & & \end{array}$

$\begin{array}{llllllll} & \mathrm{U} & \mathrm{U} & \mathrm{U} & \mathrm{U} & \mathrm{U} & & \mathrm{X}\end{array}$

$\begin{array}{llllll}- & \text { U } & \text { U } & \text { U } & \text { U } & \\ \end{array}$

\begin{tabular}{lll|l|l|l|l} 
& - & $U$ & $\mathrm{U}$ & $\mathrm{U}$ & & $\mathrm{X}$
\end{tabular}

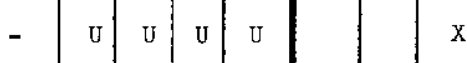

\begin{tabular}{ll|l|l|l|l|l}
- & $\mathrm{U}$ & $\mathrm{U}$ & $\mathrm{U}$ & $\mathrm{U}$ & & \\
& & & &
\end{tabular}

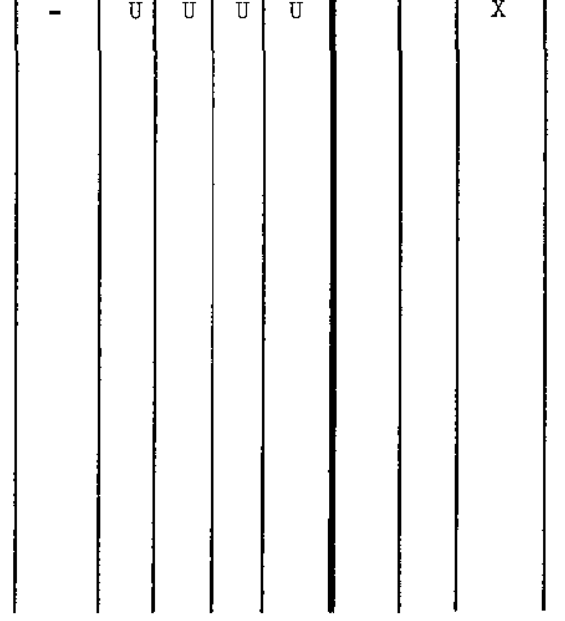


PLATES 


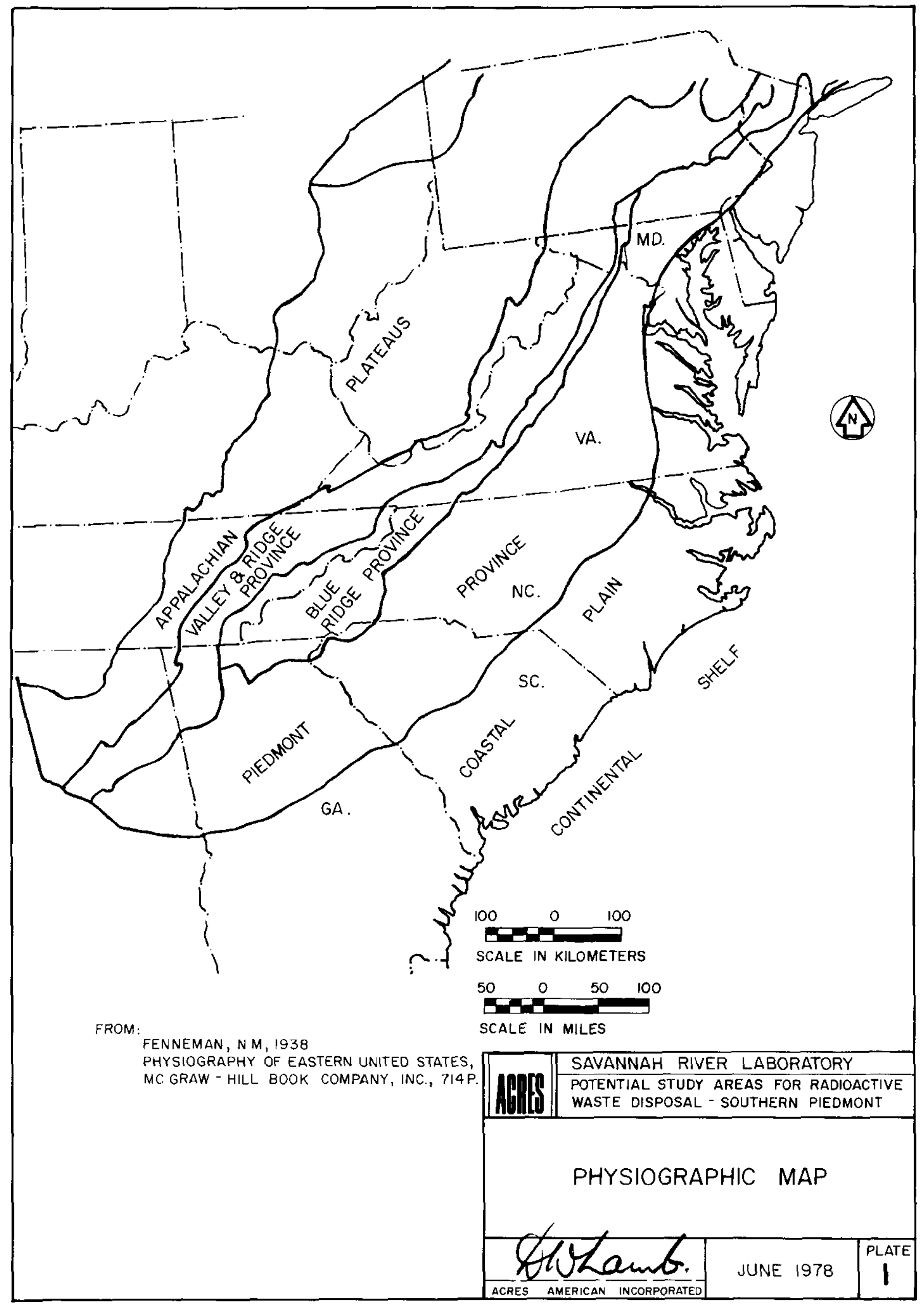




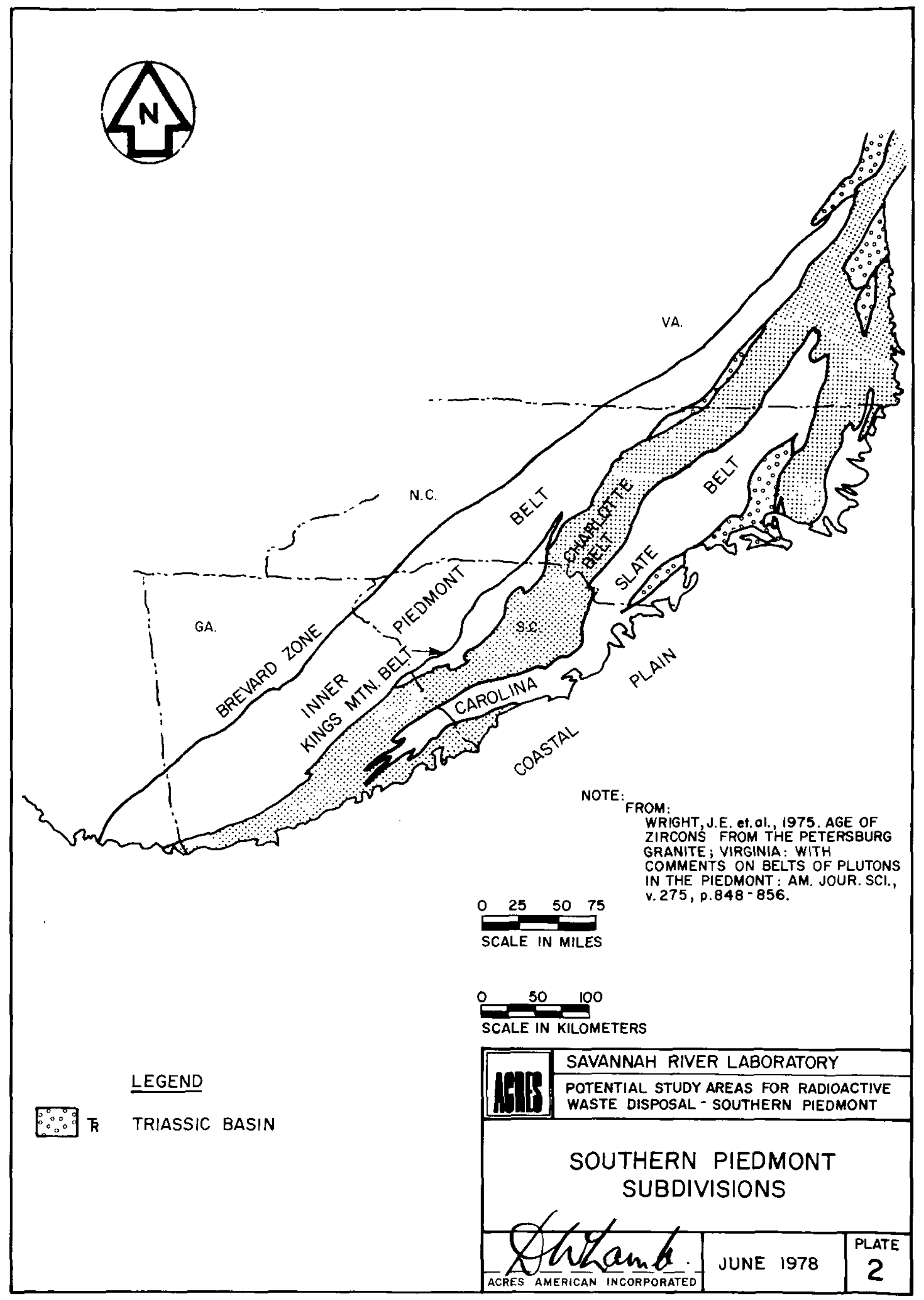




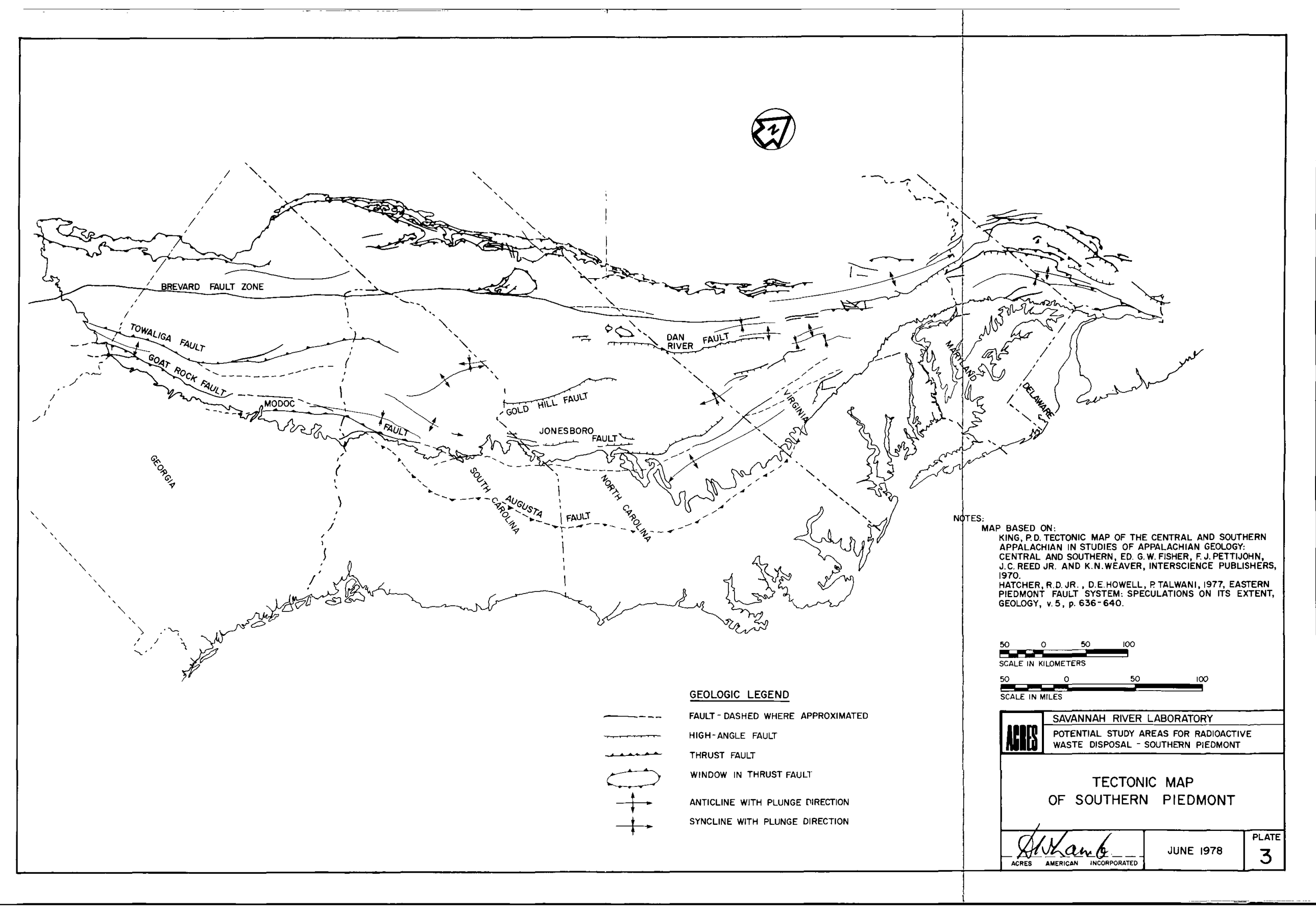




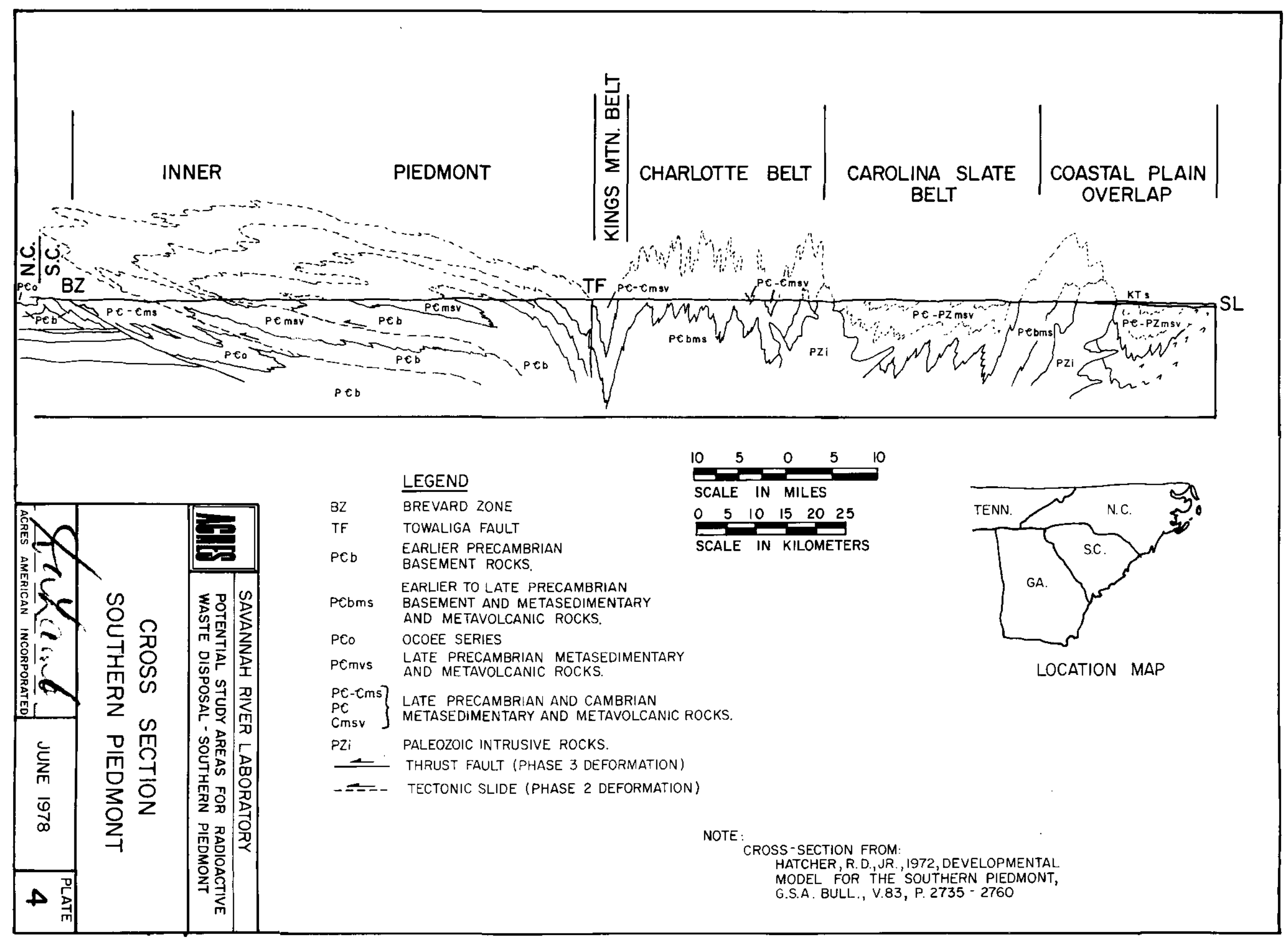




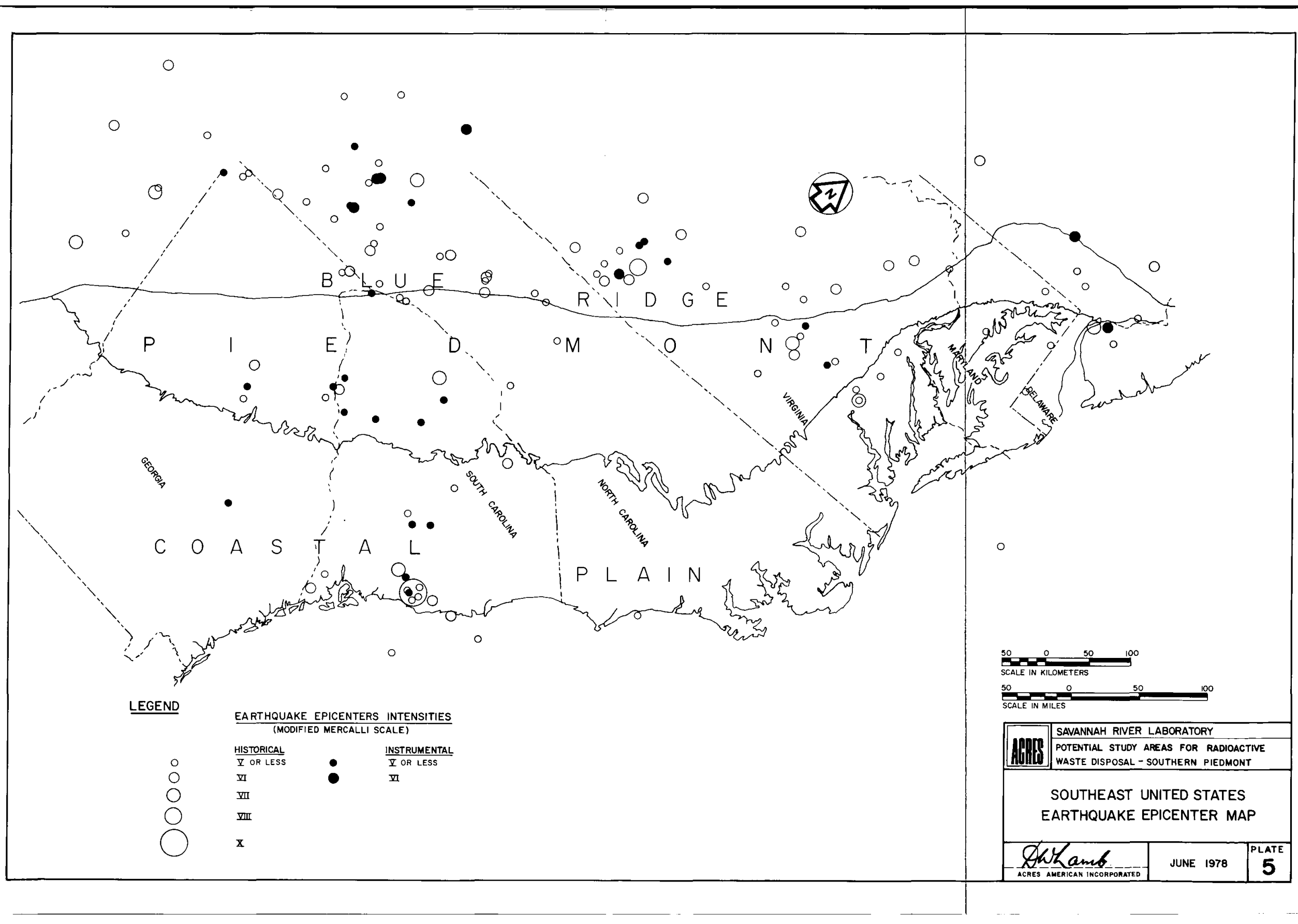




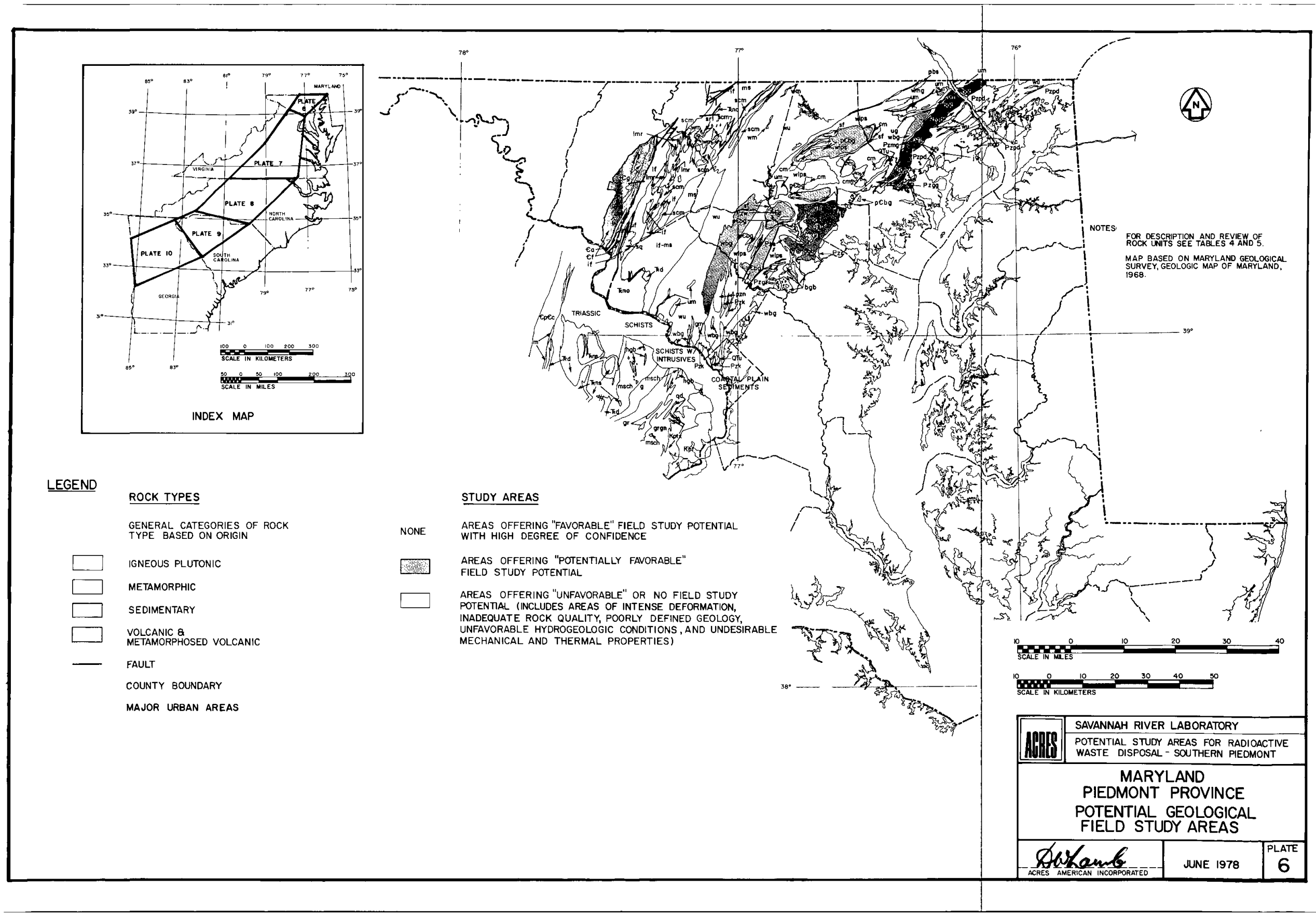




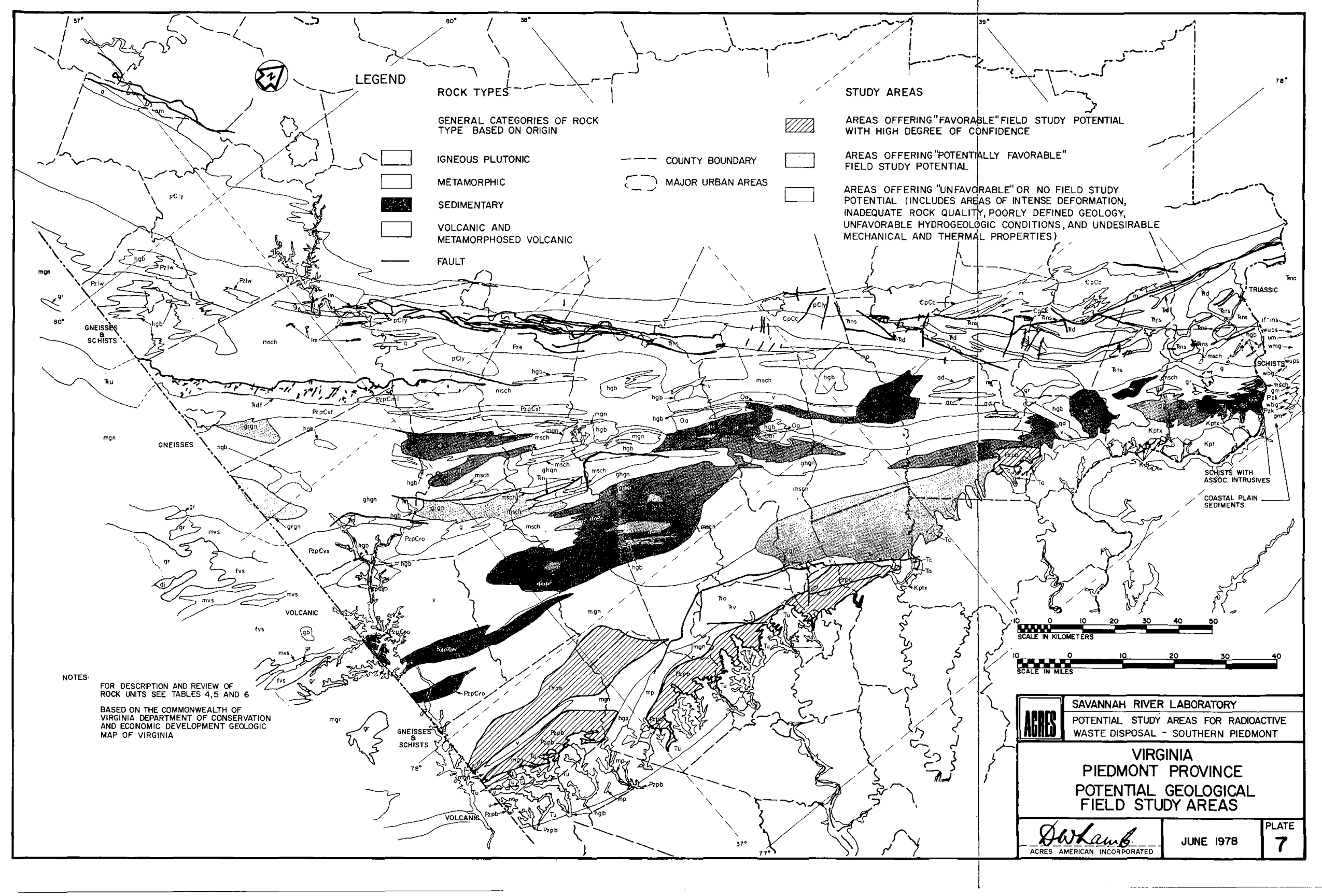




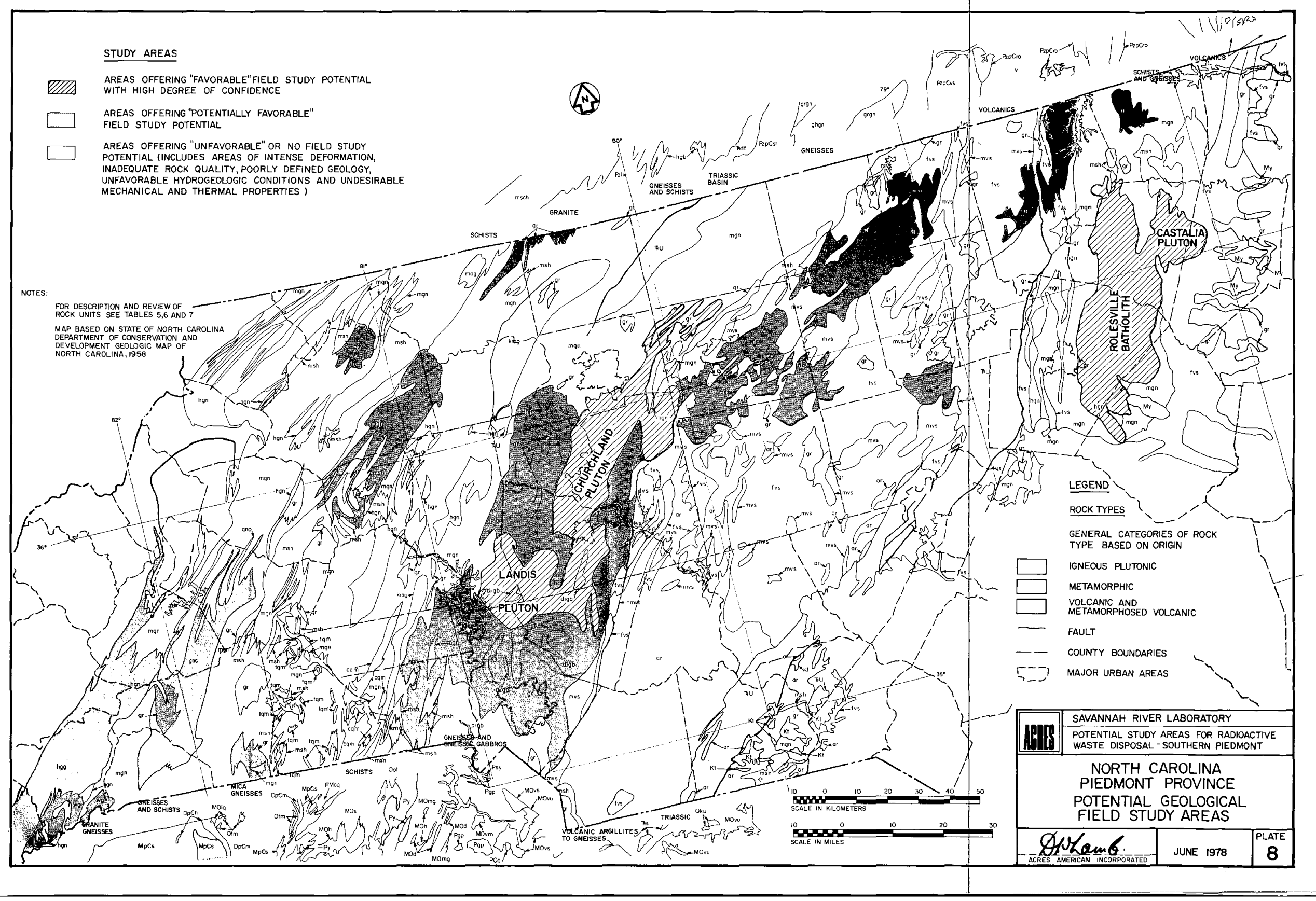




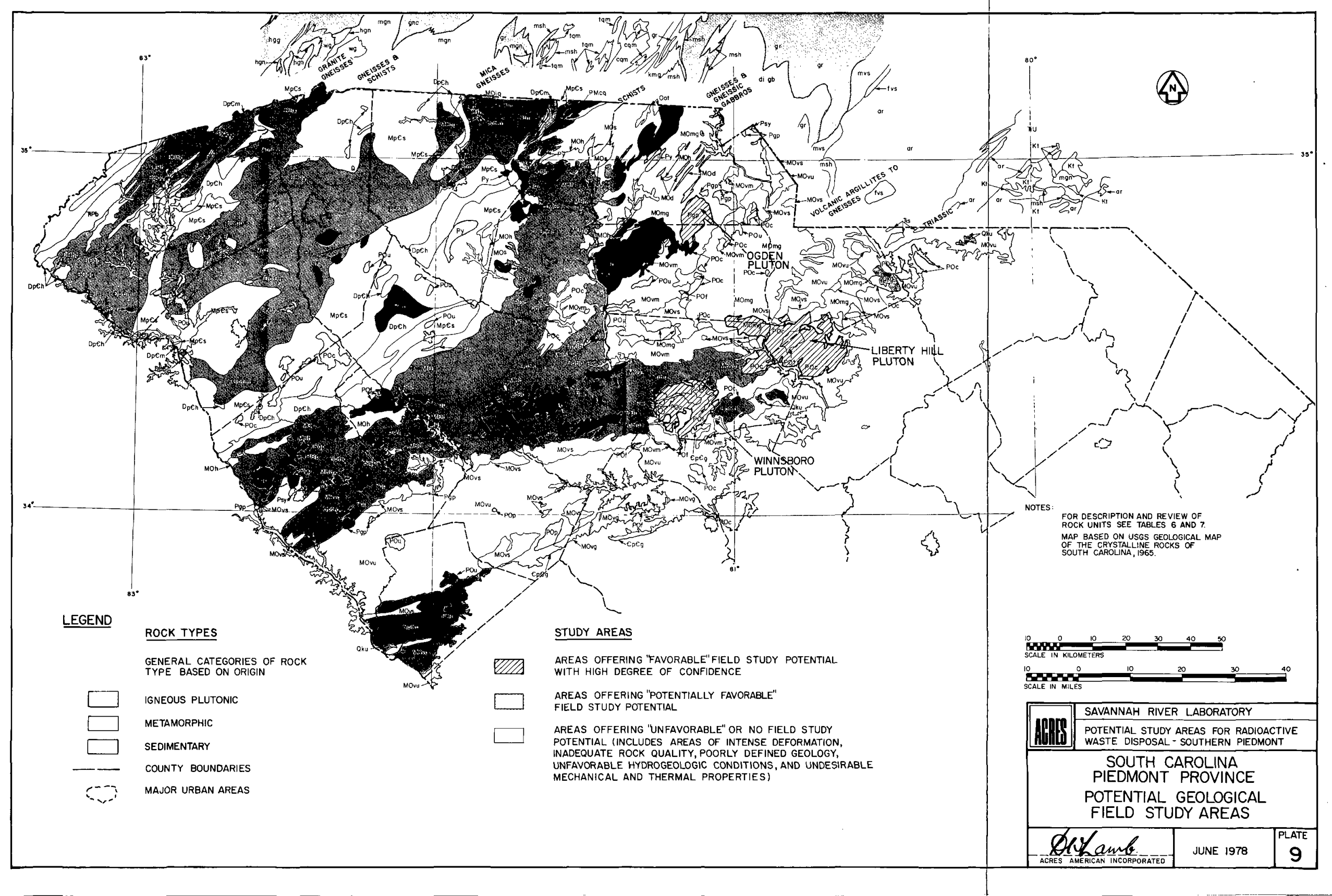




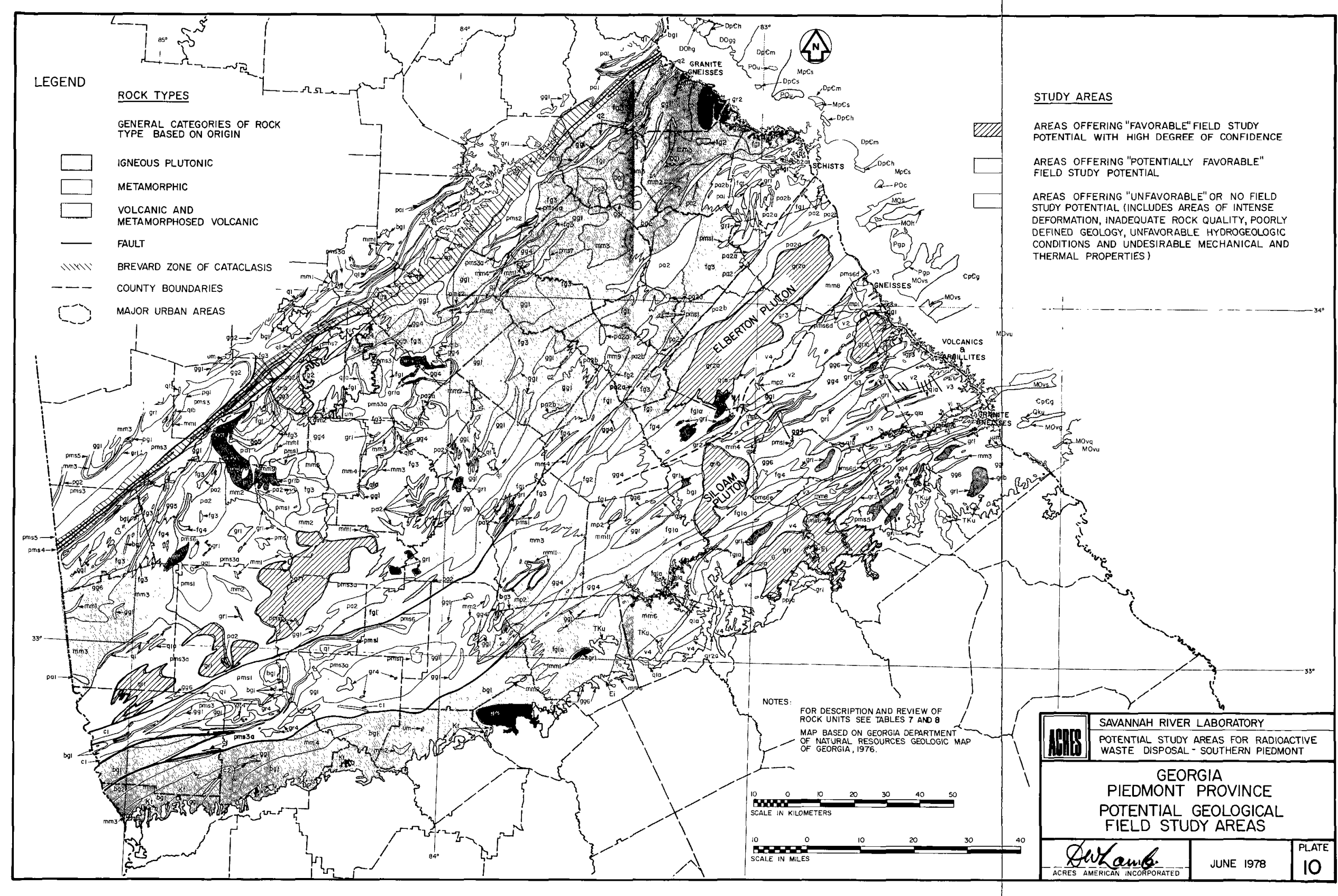


BIBLIOGRAPHY 


\section{BIBL IOGRAPHY}

This section contains a partial bibliography of Piedmont geologic literature. The intent of this bibliography is to provide a basis for additional studies in those areas designated as showing "favorable" or "potentially favorable" siting potential for deep geologic disposal of radioactive wastes. 


\section{BIBLIOGRAPHY - Maryland}

Alterman, I.B., 1976, Tectonic significance of late faults in the Maryland Piedmont; GSA \{abs programs\}, vol. 8, no. 2, p. 122-123.

Bromery, R.W., 1968, Geological interpretation of aeromagnetic and gravity surveys of the northeastern end of the Baltimore - Washington anticlinorium, Harford, Baltimore, and part of Carroll counties, Maryland; Master's, 1968.

Cleaves, E.T., 1973, Weathering and landscape development in Maryland's eastern Piedmont; A disequilibrium denudation situation?; GSA $\{a b s\}$, vol. 5 , no. 7, p. 577 .

Cloos, E. \& Hershey, H.G., 1936, Structural age determination of Piedmont intrusives in Maryland; National Acad. Sci. Proc., U. 22, no. 1, p. 71-80.

Cohen, C.J., 1937, Structure of the metamorphosed gabbro complex at Baltimore, Maryland; Maryland Geo1. Surv., vo1. 13, p. 215-236.

Crowley, W.P., 1969, Stratigraphic evidence for a volcanic origin of part of the Belair Belt of Baltimore Gabbro complex in Baltimore County, Maryland; GSA \{abs\}, part 1 (Northeast. Sect.), p. 10.

Crowley, W.P., et a1, 1971, New interpretations of the eastern Piedmont geology of Maryland, or, granite and gabbro or graywacke and greenstone; Maryland Geol. Surv. Guidebook no. 2, 43 p.

Crowley, W.P., 1975, Post-Grenville, pre-metamorphic history of the eastern Maryland Piedmont; GSA \{abs\}, vol. 9, no. 2, p. 130.

Crowley, W.P., 1977, Evidence for a possible Wissahickon allochthon in Maryland; GSA fabs programs\}, vol. 9, no. 2, p. 130.

Fisher, G.W., 1971, Kyanite -, staurolite-, and garnet-bearing schists in the Setters Formation, Maryland Piedmont; GSA Bul1. vol. 82, no. 1, p. 229-232.

Froelich, A.J., 1975, Surface materials map of Montgomery County, Maryland; USGS Misc. Invest. Ser. no. I-920-A, geol. map 1:62,500.

Froelich, A.J., 1975, Thickness of overburden map of Montgomery County, Maryland; USGS Misc. Invest. Ser. no. I-920-B, geol. map $1: 62,500$.

Froelich, A.J., 1975, Contour map of the base of saprolite, Montgomery County, Maryland; USGS Misc. Invest. Ser. no. I-920-C, geol. $\operatorname{map} 1: 62,500$. 
Froelich, A.J., 1975, Bedrock map of Montgomery County, Maryland; USGS Misc. Invest. Ser. no. I-920-D, geol. map 1:62,500.

Froelich, A.J., 1975, Map showing mineral resources of Montgomery County, Maryland; USGS Misc. Invest. Ser. no. I-920-E, econ. geol. map $1: 62,500$.

Grauert, B.W., 1972, New U-Pb isotopic analysès of zircons from the Baltimore Gneiss and the Setters Formation, Maryland Piedmont; GSA \{abs\}, vol. 4, no. 7 , p. 519 .

Grauert, B.W., 1972, New U-Pb isotopic analyses of zircons from the Baltimore Gneiss and the Setters Formation; Carnegie Inst. Wash., Yearbook, no. 71 , p. $301-305$.

Grauert, B.W., 1973, U-Pb isotopic studies of zircons from the Baltimore Gneiss of the Towson Dome, Maryland; Carnegie Inst. Wash., Yearbook, no. 72 , p.285-288.

Grauert, B.W., 1974, U-Pb systematics in heterogeneous zircon populations from the Precambrian basement of the Maryland Piedmont; Earth

Planet. Sci. Letter, vol. 23, no. 2, p. 238-248.

Herz, N., 1951, Petrology of the Baltimore Gabbro, Maryland; GSA Bul1., vol. 62, p. 979-1016.

Higgins, M.W., et a1, 1971, Correlation of metavolcanic rocks in Maryland, Delaware and Virginia Piedmont; GSA $\{a b s\}$, vol. 3, no. 5, p. 320.

Higgins, M.W., 1973, Superimposition of folding in the northeastern Maryland Piedmont and its bearing on the history and tectonics of the central Appalachians; Am. J. Sci., vol. 273-A, p. 150-195.

Higgins, M.W., 1974, Age, origin, regional relations, and nomenclature of the Glenarm series. Central Appalachian Piedmont: a reinterpretation; GSA Bul1., vol. 85, no. 1, p. 156.

Hopson, C.A., 1964, The crystall ine rocks of Howard and Montgomery counties; The Geology of Howard and Montgomery counties: Maryland Geo1. Surv., p. $27-215,270-337$.

Larrabee, D.M., 1968, Serpentine and rodingite in Hunting Hi11 Quarry, Montgomery County, Maryland: a summary; USGS Prof. Paper no. 600-D p. 195-196.

Larrabee, D.M., Serpentine and rodingite in the Hunting Hill Quarry, Montgomery County, Maryland; USGS Bull., no. 1283, 34 p. 
Mixon, R.B., et a1, 1972, Geologic map of the Quantico Quadrangle, Prince William and Stafford counties, Virginia, and Charles County, Maryland; USGS Geol. Quadrangle Map no. GQ-1044, scale $1: 24,000$.

01sen, S.N., 1977, Origin of the Baltimore Gneiss migmatites at Piney Creek, Maryland; GSA Bu11., vol. 88, no. 8, p. 1089-1101.

Otton, E.G., et al, 1975, Cockeysville Quadrangle: geology, hydrology and mineral resources; Maryland Geol. Surv., Quadrangle Atlas, no. 3 , scale $1: 24,000,4$ p.

Pavlides, L., 1974, Age, origin, regional relations, and nomenclature of the Glenarm series. Central Appalachian Piedmont: a reinterpretation, discussion; GSA Bul1., vol. 85, no. 1, p. 153-155.

Roen, J.B. \& A.J. Froelich, 1976, Contour map of the base of saprolite, Howard County, Maryland; USGS Misc. Field Stud. Map no. MF-772-A, geol. map 1:62,500.

Segovia, A.V., 1974, Interactions of geologic processes and engineering works along parts of the northwest branch of the Anacostia River, Prince Georges and Montgomery counties, Maryland; GSA \{abs\}, vol. 6 , no. 1, p. 70 .

Seiders, V.M., \& M.W. Higgins, 1976, Superimposition of folding in the northeastern Maryland Piedmont and its bearing on the history and tectonics of the central Appalachians, discussion and reply; Am. J. Sci., vol. 276, no. 6, p. 748-765.

Shifflett, C.M. \& A.V. Segovia, 1976, Geologic constraints in site selection for engineering works in the Maryland Piedmont, Montgomery County, Maryland; GSA \{abs programs\}, vol. 8, no. 2, p. 266.

Southwick, D.L. \& J.P. Owens, 1968, Geologic map of Harford County, Maryland; Maryland Geol. Surv., County Geol. Map CGM-1, scale $1: 62,500$.

Southwick, D.L., 1970, The Piedmont: structure and petrology of the Harford County part of the Baltimore - State Line gabbro - peridotite complex; Studies of Appalachian Geology, Central and Southern, Intersci. Publ., New York, p. 397-415.

Stose, A.J. \& G.W. Stose, 1946, Geology of Carroll and Frederick counties, Maryland; Maryland Geol. Surv. p. 11-131. 
Tilton, G.R., et al, 1958, Ages of Minerals from the Baltimore Gneiss near Baltimore, Maryland; GSA Bul1., vol. 69, p. 1469-1474.

Tilton, G.R., et al, 1970, The Piedmont: zircon age measurements in the Maryland Piedmont, with special references to Baltimore Gneiss problems; Studies of Appalachian Geology, Central and Southern, Intersci. Publ., New York, p. 429-434. 


\section{BIBLIOGRAPHY - Virginia}

Abdel-Khalek, M.L. \& S.G. Khoury, 1971, Structural and metamorphic evolution of the Otter River area, west-central Piedmont, Virginia; GSA Bul1. vo1. 82, no. 3, p. 707-716.

Ayers, R.L., 1972, A note on the Richmond, Virginia earthquake of September 5, 1972; Earthquake Notes, vol. 43, no. 4, p. 17-21.

Bloomer, R.0., 1950, Late Precambrian or lower Cambrian formations in central Virginia; Am. J. Sci., vol. 248, no. 11, p. 753-783.

Bloomer, R.0., 1951, A folded overthrust and its effect upon stream development in central Virginia; Am. J. Sci., vol. 249, no.9, p. $640-653$.

Brown, W.R., 1950, The Piedmont Province in the James River basin past, present and future; Richmond, Virginia Acad. Sci. p. 482-497.

Brown, W.R., 1950, Structural framework and mineral resources of the Virginia Piedmont; McGrain, P., ed., Proceedings of the Southeastern Mineral Symposium, Kentucky Geol. Survey Ser. 9, Spec. Pub. 1 , p. 88-111.

Brown, W.R., 1951, James River synclinorium and related structures in Western Virginia Piedmont \{abs.\}; GSA Bul1., vol. 62, no. 12, part 2, p. 1547.

Brown, W.R. \& H.C. Sunderman, 1954, Geologic relations in and between the Esmont and Arvonia Slate Districts, Virginia \{abs\}; GSA Bull., vol. 65 , no. 12, part 2, p. 1356 .

Brown, W.R., 1958, Geology and mineral resources of the Lynchburg Quadrangle, Virginia; Virginia Div. Mineral Res. Bul1. 74, xiii, $99 \mathrm{p}$.

Brown, W.R., 1966, Roadlog and guide to the geology of the Arvonia Slate District, Virginia; 1966 Pick and Hammer Club field trip, Virginia Div. Mineral Res.

Brown, W.R., \& T.B. Griswold, 1970, Superposed folding in the Arvonia Slate District, Virginia; GSA \{abs\} vol. 2, no. 3, p. 198.

Brown, W.R. \& E. Rosa, 1974, Multiple deformations and contrasting minor structural elements in major rock units near Lynchburg, Virginia; GSA \{abs\}, vol. 6, no. 4, p. 337. 
Brown, W.R., 1976, Tectonic melange (?) in the Arvonia slate district of Virginia; GSA \{abs program\}, vol. 8, no. 2, p. 142.

Burns, J.R., 1950, Geology of Fredericksburg and vicinity; Thesis (M.A.), Univ. of Virginia; \{abs\} Virginia J. Sci., vol. 1, no. 4, p. 335.

Cameron, C.C., 1959, Geology of Lebannon (Fairfax County), Virginia; Atlantic Naturalist, vol. 14, no. 1, p. 22-29.

Casadeva11, T., 1977, The Nutbush Creek dislocation, Vance County, North Carolina and Mecklenburg County, Virginia: a possible fault of regional significance; GSA \{abs programs\}, vol. 9, no. 2 , p. 127-128.

Clement, S.C. et al, 1974, A possible domal structure in the outer Piedmont of Virginia; GSA \{abs\}, vol. 6 , no. 1, p. 12.

Clement, S.C. \& B.K. Goodwin, 1977, Metamorphic zonation of the eastern Piedmont of Virginia; GSA \{abs program\}, vol. 9, no. 2, p. 129-130.

Conley, J.F., et al, 1971, Rocks of the southwestern Virginia Piedmont and other relationships to the BTue Ridge Anticlinorium, James River Synclinorium, Brevard Fault and Sauratown Mountain Anticlinorium; GSA \{abs\}, vol. 3, no. 7 , p. 530 .

Conley, J.F. \& W.S. Henika, 1973, Geology of the Snow Creek, Martinsville Easí, Price, and Spray quadrangles, Virginia; Virginia Div. Mineral Res., Rep. Invest., no. 33, 71 p.

Conley, J.F. \& S.S. Johnson, 1975, Geologic mapping in the central Virginia Piedmont using geophysical data; GSA \{abs\} vol. 7, no. 4, p. 479.

Conley, J.F. \& S.S. Johnson, 1975, Road log of the geology from Madison to Cumberland counties in the Piedmont, central Virginia; Virginia Mineral., vol. 21 , no. 4, p. 29-38.

Cooper, B.N., 1954, Groundwater in Virginia; Mineral Industries J., vol. 1 , no. 4, p. $5-6,8$.

Crist, C.W., 1959, A petrographic study of garnet outcrops in the Virginia Piedmont; Thesis (M.S.), Univ. of Virginia, 109 p.; \{abs\} Virginia J. Sci., vol. 10, no. 4, p. 290.

Dietrich, R.V., 1953, Geologic section across western Floyd County, Virginia; \{abs\} Virginia J. Sci., vol. 4, no. 4, p. 265. 
Edwards, J., Jr., 1956, Cleavage in the Arvonia Slate, Buckingham County, Virginia; \{abs\} Virginia J. Sci., vol. 7, no. 4, p. 322.

Fairley, W.M. \& J.H. Prostka, 1958, Soapstone Belt, a preliminary geologic map of part of Albemarle and Nelson counties, Virginia; Virginia Div. Mineral Res., scale 1:250,000.

Fara, M., 1957, Relationship of igneous intrusion to the North Mountain thrust, North River Gap area; \{abs\} Virginia J. Sci., vol. 8, no. 4, p. 334-335.

Froelich, A.J., 1976, A geologic and environmental guide to northern Fairfax County, Virginia; GSA, Boulder, Colo., USA, 1976 Short course no. 3 field trip guidebook, 28 p.

Garner, T.E., Jr., 1956, The igneous rocks of Pendleton County, West Virginia; West Virginia Geol. Surv., Rep. Invest., no. 12, p. 37 .

Gathright, T.M., II, \& P.G. Nystrom, Jr., 1974, The geology of the Ashby Gap Quadrangle, Virginia; Virginia Div. Mineral Res., Rep. Invest., no. $36,55 \mathrm{p}$.

Geyer, V.H., 1955, Groundwater in Virginia Piedmont; Virginia Minerals, vol. 1 , no. 3, p. T-5.

Glover, L., III, et al, 1971, Virgilina Phase (Precambrian and early Cambrian (?)) of the Avalonian Orogeny in the central Piedmont of Virginia and North Carolina; GSA \{abs\}, vol. 3, no. 7, p. 581-582.

Glover, L., III \& A.K. Sinha 1973, The Virgilina deformation. A late Precambrian to early Cambrian (?) orogenic event in the centra] Piedmont of Virginia and North Carolina; Am. J. Sci., vol. 273-A, p. 234-251.

Glover, L., III, 1976, Tectonics of the Piedmont of North Carolina and Virginia: review and speculation; GSA \{abs programs\} vol. 8, no. 2, p. 181.

Gooch, E.0., 1956, Evidence of reworking of Lynchburg formation in northcentral Virginia; GSA Bul1. \{abs\} vol. 67, no. 12, part 2, p. 1751.

Gooch, E.0., 1957, Vermiculite in the Virginia Piedmont; \{abs\} Virginia J. Sci., vol. 8, no. 4, p. 330-331.

Graham, G.M., 1975, An integrated geological and geophysical study of the Diana Mills Pluton, Virginia; Master's 1975, Kentucky. 
Graham, G.M., et al, 1975, Gravity, magnetic, and geologic studies of igneous bodies in the Piedmont of central Virginia; GSA \{abs\}, vol. 7, no. 4, p. 493.

Greenburg, J.K., 1975, A tectonic - geophysical investigation of a portion of the Blue Ridge - Piedmont transition in the Martinsville, Virginia area; Master's, 1975, Kentucky

Griffitts, W.R., et al, 1953, Mica deposits of the southeastern Piedmont part 3, Ridgeway - Sandy Ridge District, Virginia - North Carolina; part 4, Outlying deposits in Virginia; USGS Prof. Paper $248-\mathrm{c}$, iv, p. 141-202.

Harper, C.T., et al, 1973, The Arvonia Slate: a useful standard for K-Ar dating; GSA $\{$ abs\}, vol. 5, no. 5, p. 402.

Henika, W.S., 1969, Geology of the Buckingham injection complex (age uncertain - probably mid to Tate Paleozoic) (Buckingham County), Virginia; Master's 1969.

Herzog, L.F., II, \& W.H. Pinson, Jr., 1955, The Sr and Rb contents of the granite (R.I.) and the diabase W-1 (Va.); Geochim. et Cosmochim. Acta, vol. 8, no. 5-6, p. 295-298.

Higgins, M.W., et a1, 1971 , Correlation of metavolcanic rocks in Maryland, Delaware, and Virginia Piedmont; GSA \{abs\} vol. 3, no. 5, p. 320.

Howard, J.J., 1976, Polymetamorphism in Precambrian rocks of the Virginia Piedmont; GSA \{abs programs\}, vol. 8, no. 2, p. 200.

Huddle, J.W., et a1, 1955, Detailed logs of 28 wildcat wells in Lee, Wise, Buchanan, Montgomery, and Dickenson counties, Virginia; USGS open-file report.

Huffman, A.C., Jr., 1976, Bedrock geology of northern Virginia within the Capital Beltway; GSA \{abs programs\}, vol. 8. no. 2, p. 204.

Johnston, P.M., 1956, Geology of the Great Falls Park area, Fairfax County, Virginia; USGS open-file report, $5 \mathrm{p}$.

Kaldy, W.J. \& W.R. Brown, 1977, Geology of the Sherwill Dome of the southwestern Piedmont of Virginia; GSA \{abs programs\}, vol. 9, no. 2, p. 152.

Khoury, S.G. \& M.L. Abdel-Khalek, 1970, Relationship between microscopic fabrics and mesoscopic structures in a deformed supracrustal assemblage. West-central Piedmont, Virginia; J. Geol. UAR, vol. 14, no. 2, p. 85-95. 
Khoury, S.G. \& M.L. Abdel-Khalek, 1973, Relationship between microscopic fabrics and mesoscopic structures in a deformed supracrustal assemblage. West-central Piedmont, Virginia; Southeast. Geol., vol. 15, no. 1, p. $1-16$.

King, P.B., 1950, Geology of the Elkton area, Virginia; USGS Prof. Paper 230, 82 p.

Kingston, M. \& R.E. Weems, 1976, The metamorphic terrain of Hanover County, Virginia; GSA [abs programs\}, vol. 8, no. 2, p. 210-211.

Kulp, J.L., \& L.E. Long, 1957, Chronology of major metamorphic events in southeastern United States; $\{a b s\}$ Am. Geophys. Union Trans., vol. 39 , no. 3 , p. 522 .

KuTp, J.L., et a1, 1957, Age of the Piedmont and southern Appalachians; \{abs\} GSA Bu11., vol. 68, no. 12, part 2, p. 1758-1759.

Legrand, H.E., 1959, A summary of groundwater conditions in the Piedmont province of Virginia; Virginia Minerals, vol. 5, no. 4, p. 1-7.

Lukert, M.T., \& E.B. Nuckols, III, 1976, Geology of the Linden and Flint Hill quadrangles, Virginia; Virginia Div. Mineral Res., Rep. Invest., $83 \mathrm{p}$.

Lukert, M.T., 1977, Discordant zircon age of the 01d Rag Granite, Madison County, Virginia; GSA \{abs programs\}, vol. 9, no. 2, p. 162 .

Major, V.L., 1967, Geological field trip in Fairfax County, Virginia; Master's, 1967, Virginia State.

Mitchel1, J.T., 1973, Petrology of Charlotte Belt metamorphic rocks south of Danville, Virginia; GSA \{abs\}, vol. 5, no. 5, p. 420-421.

Nelson, W.A., 1954, Geological section along Roanoke River from Clarksville, Virginia to Roanoke Rapids, North Carolina; \{abs\} Virginia $J$.

Sci., vol. 5, no. 4, p. 297-298.

Nelson, W.A., 1954, Notes on the structure of the Virginia Piedmont; \{abs\} GSA Bul1., vol. 65, no. 12, part 2, p. 1365.

Nelson, W.A., 1955, Notes on the general structure of the Piedmont folded Appalachian Mountains in central Virginia; Appalachian Geol. Soc., Guidebook, May, 1955, \{Charleston\} p. 14-16.

Neison, W.A., 1956, The correlation of Virginia, Piedmont, strata and an interpretation of Piedmont structure based on this correlation; \{abs\} Virginia J. Sci, vol. 7, no. 4, p. 328. 
Nelson, W.A., 1956, Structure and geology of the Virginia Piedmont; \{abs\} GSA Bul1., vol. 67, no. 12, part 2, p. 1755-1756.

Pavlides, L., 1976, Piedmont geology of the Fredericksburg, Virginia, area and vicinity; GSA, Boulder, Colo., USA, 1976, Guidebook for field trips 1 and $4,44 \mathrm{p}$.

Pegau, A.A. \& W.B. Brent, 1956, Granites and phyllites of southeastern Piedmont of Virginia and their relation to the tectonic map of this area; \{abs\} GSA Bu11. 66, no. 12, part 2, p. 1695; \{abs\} Virginia J. Sci., vol. 7, no. 4, p. 326.

Pilant, W.L., \& M.S. Robison, 1977, Geophysical evidence for faulting transverse to the regiona] trend in the Lynchburg, Virginia, area; GSA \{abs programs\}, vo1. 9, no. 2, p. 174.

Poole, J.L., 1974, Notes on some abandoned copper, lead, and zinc mines in the Piedmont of Virginia; Virginia Div. Mineral Res., Virginia Mineral. vol. 20, no. 2, p. 9-15.

Ragland, P.C., 1974, Geochemical evidence for the existence of two igneous rock series, Martinsville igneous complex, Virginia; GSA \{abs\}, vol. 6 , no. 4, p. 390.

Redden, J.A., 1963, Stratigraphy and metamorphism of the Altavista area; Virginia Polytechnic Institute Eng. Ext. Ser., GSA, Southeast. Sect., Guidebook II, p. 77-99.

Rogers, H.G., 1977, Map showing landforms of Fairfax County, Virginia; USGS, open-file report, no. 77-89, geomorph. map 1:48,000.

Scheible, P., 1975, Geology of Gladehi11, Penhook, and Mountain Valley quadrangles, Virginia: a reinterpretation of the stratigraphy of the James River synclinorium; GSA $\{a b s\}$, vol. 7, no. 4, p. 531.

Seiders, V.M., et a1, 1975, Age of plutonism and tectonism and a new minimum age limit on the Glenarm series in the northeast Virginia Piedmont near Occoquan; Am. J. Sci., vol. 275, no. 5, p. 481-511.

Schufflebarger, T.E., Jr., 1953, Outline of the geology of Poor Mountain, Roanoke and Floyd counties, Virginia; \{abs\} Virginia J. Sci., vol. 4, no. 4, p. 266.

Stose, G.W. \& A.J. Stose, 1948, Stratigraphy of the Arvonia slate, Virginia; Am J. Sci., vol. 246, p. 393-412. 
Subitzky, S., 1955, Summary of geology and groundwater conditions in the Fredericksburg District, eastern Spotsylvania County, Virginia - a preliminary report; Virginia Div. Geol. Mineral Res. Cir. 4, 32 p.

Sweet, P.C., 1976, Abandoned copper mines and prospects in the Virgilina District, Virginia; Virginia Mineral., vol. 22, no. 3, p. 25-34.

Theismayer, L.R., 1939, Varved slates in Fauquier County, Virginia; Virginia Geol. Surv. Bul1. 51-D, p. 105-118.

Thomas, P.C., 1973, Probable rejuvenation of the Piedmont in the James River drainage basin; Master's, 1973, North Carolina: Chapel Hill

U.S. Geological Survey, Aeromagnetic map of the Danville Quadrangle, Pittsylvania County, Virginia, and Caswell County, North Carolina; USGS Geophys. Invest. Map no. GP-745, magn. surv. map 7:62,500.

U.S. Geological Survey, Aeromagnetic map of the Milton Quadrangle, Halifax and Pittsylvania counties, Virginia, and Caswell and Person counties, North Carolina; USGS Geophys. Invest. Map no. GP-746, magn. surv. map $1: 62,500$.

U.S. Geological Survey, Aeromagnetic map of the South Boston Quadrangle, Halifax County, Virginia, and Person and Granville counties, North Carolina; USGS Geophys. Invest. Map no. GP-747, magn. surv. map $7: 62,500$.

White, W.A., 1953, Systematic drainage changes in the Piedmont of North Carolina and Virginia; GSA Bu11., vol. 64, no. 5, p. $561-579$.

Wright, J.E., et al, 1975, Age of zircons from the Petersburg Granite, Virginia: with comments on belts of plutons in the Piedmont; Am. J. Sci., vol. 275 , no. 7 , p. 848-856. 
Bain, G.L., 1964, Metavolcanic and metasedimentary rocks in Chatham and Randolph counties, North Carolina; Carol ina Geol. Soc. Field trip Guidebook, p. 1-6.

Bain, G.L. \& J.D. Thomas, 1966, Geology and groundwater in the Durham area North Carolina; N.C. Dept. Water Resources, Groundwater Bull . $7,147 \mathrm{p}$.

Be11, H., 1969, The regional setting of hydrothermal alteration in part of South Carolina and North Carolina; GSA \{abs.\}, part 7 (Annu. Meeting), p. 300.

Best, D.M., et al, 1973, Gravity investigation of the depth of source of the Piedmont gravity gradient in Davidson County, North Carolina; GSA Bul1., vol. 84, no. 4, p. 1213-1216.

Bowman, J.T., 1970, Compositional variation in granite of eastern Wake and northwestern Johnston counties, North Carolina; Master's 1970.

Butler, J.R., 1963, Rocks of the Carolina Slate Belt in Orange County, North Carol ina; Southeast Geol., vol. 4, no. 3, p. 167-185.

Butler, J.R., 1964, Chemical analyses of rocks of the Carolina Slate Belt; Southeast. Geol., vol. 5, no. 2, p. 101-112.

Butler J.R., 1969, Field and petrographic relationships among intrusive rocks of the Carolina Piedmont; GSA \{abs\}, Part 4 (Southeast Sect.), p. 12 .

Butler, J.R., 1973, Orbicular rocks from Davie County, North Carolina Piedmont; Southeast. Geol., vol. 15, no. 3, p. 127-139.

Butler, J.R. \& P.D. Fullagar, 1974, Southeastern margin of the Appalachians in the Carolinas and eastern Georgia, U.S.A.; Geol. Asso. Can.--Minera1. Assoc. Can., Canada \{annual meet. - program abs.\} p. 16.

Butler, J.R. \& P.D., Fullagar, 1977, The Gold Hill Fault Zone in the Carolinas; age of movement and southwestern extention; GSA a abs. programs \} vol. 9, no. 2, p. 125.

Cabaup, J.J., 1969, Origin and differentiation of the gabbro in the Concord Ring Dike (late Paleozoic) Cabarrus County, North Carolina Piedmont; Master's 1969.

Carpenter, P.A. III, 1970, Geology of the Wilton area; Elisha Mitchel1 Sci. Soc. J., vol. 86, no. 4, p. 178-179. 
North

Carolina

Carpenter, P.A., III, 1970, Geology of the Wilton area, Granville County, North Carolina; Master's 1970.

Carrilho, C.D., 1973, Geology of the northeast Burlington Quadrangle (Alamance County, North Carolina); Master's 1973, North Carolina State.

Casadeva11, T., 1977, The Nutbush Creek dislocation, Vance County, North Carolina, and Mecklenburg County, Virginia: a possible fault of regional significance; GSA \{abs. programs\} vol. 9, No. 2 p. 127-128.

Centini, B.A., 1969, Structural geology of the Hanging Rock area, Stokes County, North Carolina; Diss. Abs., Vol. 29, no. 7, p. 2492B.

Conley, J.F., 1962, Geology and mineral resources of Moore County, North Carolina; North Carolina Div. Mineral Res. Bul1. 76, 40 p.

Constantino, S.E., 1971, Geology of Cleveland Gabbro (Lower Paleozoic). Rowan County, North Carolina; Master's 1971.

Council, R.J., 1954, A preliminary geologic report on the commercial rocks of the volcanic slate series, North Carolina; North Carol ina Div. Mineral Res. Inf. Cir. 12, 30p.

Emmons, E., 1856, Geological report of the Midland Counties of North Carolina; North Carolina Geol. Sur., 351 p.

Espenshade, G.H. et al., 1975, Geologic map of the east half of the Winston - Salem Quadrangle, North Carolina - Virginia; U.S.G.S., Misc. Invest. Ser. no. I-709-B, geol. map $1: 250,000$.

Floyd, E.0., 1965, Geology and groundwater resources of the Monroe area, North Carolina; North Carolina Dept. Water Res. Groundwater Bull. 5, $109 \mathrm{p}$.

Fullagar, P.D., 1969, Whole-rock rubidium - strontium ages of the Liberty Hill Pluton, South Carolina, and the Salisbury Pluton, North Carolina; GSA \{abs\}, part 4, (Southeast Sect.), p. 26.

Fullagar, P.D., et al, 1971, Petrochemical and geochronological studies of plutonic rocks in the southern Appalachians: 1, the Salisbury Pluton; GSA Bull., vol. 82, no. 2, p. 409-415.

Glover, L., III, et al, 1971, Virgilina phase (Precambrian and early Cambrian (?)) of the Avalonian orogeny in the central Piedmont of Virginia and North Carolina; GSA $\{a b s\}$, vol. 3, no. 7, p. 587-582.

Glover, L., III, \& Sinha, A.K., 1973, The Virgilina Deformation. A Late Precambrian to Early Cambrian (?) orogenic event in the central Piedmont of Virginia and North Carolina; Am. J. Sci., vol. 273-A, p. 234-251. 
Glover, L., III, \& Werner, S.G., 1973, North - trending left-lateral strike-slip faulting of Late Precambrian or Early Cambrian age in the Carolina Slate Belt; GSA \{abs.\}, vol. 5, no. 5, p. 400.

Glover, L., III, 1976, Tectonics of the Piedmont of North Carolina and Virginia; review and speculation; GSA \{abs. programs\}, vol. 8, no. 2, p. 181.

Green, G.B., Jr., et al, 1977, Carolina Slate Belt rocks of the Goldston and Bear Creek quadrangles, Chatham and Moore counties North Carolina; GSA \{abs program\}, vol. 9, no. 2, p. 141-142.

Hadley, J.B. \& Nelson, A.E., 1970, Caesars Head Quartz Monzonite in the western Carolina Piedmont; USGS Bul1, no. 1324-A, p. 23-24.

Hadley, J.B., 1973, Igneous rocks of the Oxford area, Granville County, North Carolina; Am. J. Sci., vol. 273-A, p. 217-233.

Hadley, J.B., 1974, Geologic map of the Oxford Quadrangle, Granville and Vance counties, North Carolina; USGS, Misc. Field Stud. Map no. MF-608, geol. map 1:62,500.

Harper, S.B. et al, 1977, Geochronology of the granitic gneisses of the Inner Piedmont, northwestern North Carolinas; GSA \{abs programs\}, vol. 9 , no. 2 , p. 144.

Hermes, 0.D., 1969, Comparative petrochemistry of coexistent mafic silicates from the Mecklenburg Gabbro and metagabbro; GSA \{abs.\}, part 4 (Southeast. Sect.), p. 35-36.

Horton, J.W., Jr. \& Butler, J.R., 1977, Structural geology of the Kings Mountain and Inner Piedmont belts in the Kings Mountain area, North and South Carolina; GSA \{abs. programs\}, vol. 9, no. 2, p. 148 .

Hurley, B.W., 1974, Geology of the 01d Fort area, McDowell County, North Carolina; Master's 1974, North Carolina: Chapel Hill.

Jackson, N.M., Jr., 1973, Public water supplies of North Carolina;

Part 2; Southern Piedmont; U.S.G.S., Raleigh, N.C., 255 p.

Jackson, N.M., Jr., 1974, Public water supplies of North Carolina; Part 3. Mountains and western Piedmont; N.C. Dept. Nat. Econ. Res., Raleigh, N.C., U.S.A., 238 p.

Jonas, A.I., 1932, Structure of the metamorphic belt of the southern Appalachians; Am. J. Sci., 5th Ser., vol. 24, p. 228-243.

Kautzman, R.R., \& Cavaroc, V.V., 1973. Temporal relation between urbanization and reservoir sedimentation: A case study in the North Carolina Piedmont; Assoc. Eng. Geol. Bul1., vol. 10, no. 3 , p. 195-218. 
Keith, A. \& D.B. Sterrett, 1931, Description of the Gaffney and Kings Mountain quadrangles (South Carolina - North Carolina); USGS, Geol. Atlas, Folio 222, $13 \mathrm{p}$.

Kesel, R.H., 1974, Inselbergs on the Piedmont of the Virginia, North Carolina, and South Carolina; types and characteristics; Southeast Geol., vol. 16, no. 1, p. 1-30.

Kish, S.A., \& P.D. Fullagar, 1977, Plutonic history of the Inner Piedmont near Shelby, North Carolina; GSA \{abs programs\}, vol. 9, no. 2, p. 155.

LeGrand, H.E. \& M.J. Mundorff, 1952, Geology and groundwater in the Charlotte area, North Carolina; N.C. Div. Mineral Res. Bull. 63, 88 p.

Lemmon, R.E., 1969, Chemical trends in the Salisbury Granitic Pluton, North Carolina; GSA \{abs\}, part 4 (Southeast. Sect.) p. 45.

Mann, V.I., 1969, Gravity patterns over some igneous intrusives in the Piedmont of North Carol ina; GSA \{abs\}, part 4 (Southeast. Sect.), p. 48 .

Marsh, 0.T., \& R.L. Laney, 1966, Reconnaissance of the groundwater resources in the Waynesville area, North Carolina; N.C. Dept. Water Res. Groundwater Bu11. 8, $131 \mathrm{p}$.

McConnel1, K.I., et al, 1976, Geology of the Tate Precambrian intrusive complex and associated volcanic rocks along the Flat River near Durham, North Carol ina; GSA \{abs. programs\}, vol. 8, no. 2, p. 226227.

Moore, D.W., 1972, Geomorphology of the Deep River drainage basin and Carthage area (North Carolina); Master's Thesis.

Moore, D.W., 1974, Denudation of the Deep River drainage basin and adjacent fall zone, North Carol ina; GSA \{abs\}, vol. 6, no. 4, p. 382 .

Mundorff, M.J., Geology and groundwater in the Greensboro area, North Carolina; N.C. Div. Mineral Res. Bu11. 55, 108 p.

Neathery, T.L. (Chairman), 1973, Symposium: Geology of the Blue Ridge - Ashland - Wedowee Belt in the Piedmont; Am. J. Sci., vol. 273, no. 8, p. 641-756.

Odom, A.L., \& G.S. Russell 1975, The time of regional metamorphism of the Inner Piedmont, N.C. and Smith River allochthon: inference from whole-rock ages; GSA \{abs\}, vol. 7, no. 4, p. 522-523.

Parker, J.M., III, 1971, Wake graphite and the Raleigh anticline; Elisha Mitchell Sci. Soc., J., vol. 87, no. 4, p. 164. 
Parker, J.M., III, 1968, Structure of easternmost North Carol ina Piedmont; Southeast. Geol., vol. 9, no. 3, p. 117-131.

Parker, J.M., III, 1977, Structure of Raleigh Belt of eastern Piedmont in Wake County, North Carolina; GSA \{abs programs\}, vol. 9, no. 2, p. 173.

Power, W.R. \& Forrest, J.T., 1973, Stratigraphy and paleogeography in the Murphy Marble Belt; Am. J. Sci., vol. 273, no. 8, p. 698-711.

Privett, D.R., 1972, Kyanite - sillimanite quartzites, Rowan County, North Carolina; GSA \{abs\}, vol. 4, no. 2, p. $101-102$.

Privett, D.R., 1972, Petrogenesis of porphyritic granite plutons in the central Piedmont of North Carolina; Elisha Mitchell Sci. Soc., J., vol. 88 , no. 4, p. 198.

Privett, D.R., et al, 1972, Widespread laumontization in granite to monzonite - diorite contact aureoles in the central Piedmont, Rowan and Davidson counties, North Carolina; Elisha Mitchel 1 Sci. Soc., J., vol. 88, no. 4, p. 198-199.

Privett, D.R., \& I.A. Menyaylov, 1973, Paragenesis of an unusual hydrothermal zeolite assemblage in a diorite - granite contact zone, Woodleaf, Rowan County, North Carolina; Southeast. Geol., vol. 15, no. 2, p. 105-118.

Privett, D.R., 1973, Structural significance of kyanite - sillimanite quartzites in Rowan and Iredell counties, North Carolina; Southeast. Geo1., vol. 15, no. 3, p. 169-175.

Privett, D.R., 1973, Petrogenesis of prophyritic granite plutons in the central Piedmont of North Carolina; Elisha Mitchell Sci. Soc., J., vol. 89, no. 3, p. 172-178.

Privett, D.R., 1977, The northern termination of the Gold Hill - Silver Hi11 Fault Zone GSA \{abs. programs\}, vo1. 9, no. 2, p. 175-176.

Ragland, P.C., \& J.R. Butler, 1969, Differentiation trends in the intrusive rocks of the Carolina Piedmont; GSA $\{$ abs $\}$, part 4 (Southeast Sect.) p. 66.

Ragland, P.C., \& J.R. Butler, 1972, Crystallization of the West Farrington pluton, North Carol ina, U.S.A.; J. Petrol., vol. 13, no. 3 , p. $381-404$.

Randazzo, A.F., 1969, Petrography and stratigraphy of the Carolina Slate Belt, Union County, North Carolina; Diss. Abs., vol. 29, no. 7, p. $2496 \mathrm{~B}$. 
Reed, J.C., Jr., \& B. Bryant, 1964, Evidence for strike-slip faulting along the Brevard Zone in North Carolina; GSA Bul1., vol. 75, p. 1177-1196.

Schmidt, A.T., 1972, Petrology of the Lilesville Granite Batholith Aureole, Anson and Richmond counties, North Carolina; Master's 1972.

Singletary, H.M., 1972, The geology of the Mebane Quadrangle, North Carolina; Master's 1972.

Spence, W.H., et al, 1972, Potash - silica ratios in some andesites of the Carolina Slate Belt; Elisha Mitchell Sci. Soc., J., vol. 88 , no. 4 , p. 197-198.

Spence, W.H., 1975, A model for the origin of the pyrophyllite deposits in the Carolina Slate Belt; GSA \{abs\}, vol. 7, no. 4, p. 536-537.

Spence, W.H., \& P.A. Carpenter, 1976, Metallogenic zonation and a model for the development of the Piedmont of eastern North Carolina; GSA \{abs. programs\}, vol. 8, no. 2, p. 273-274.

Stewart, D.M., \& J.L. Wooden, 1973, Geophysical evidence for a layered pluton, Meadow Flats complex, North Carolina; GSA \{abs\}, vol. 5, p. 439.

Stirewa1t, G.L., \& D.F. Dunn, 1971, Scale of refolded nappes, Inner Piedmont and Brevard Zone, North Carolina; GSA \{abs\}, vol. 3, no. 7, p. 721 .

Stromquist, A.A., \& H.W. Sundelius, 1975, Interpretive geologic map of the bedrock showing radioactivity, and aeromagnetic map of the Salisbury, Southmont, Rockwell, and Gold Hill quadrangles, Rowan and Davidson counties, North Carol ina; USGS, Misc. Invest. Ser., No. I-888, 2 sheets - geol. map and magn. surv. map $1: 48,000$.

Stuckey, J.L., \& S.G. Conrad, 1958, Explanatory text for geologic map of North Carolina; N.C. Div. Mineral Res. Bul1. 71, $51 \mathrm{p}$.

Stuckey, J.L., 1965, North Carolina: Its geology and mineral resources; Raleigh, N.C., N.C. Dept. Conserv. and Devel., $550 \mathrm{p}$.

U.S. Geological Survey, 1971, Aeromagnetic map of the Milton Quadrangle: Hal ifax and Pittsylvania counties, Virginia, and Caswell and Person counties, North Carol ina; U.S.G.S., Geophys, Invest. Map no. GP-746, magn. surv. map $1: 62,500$.

U.S. Geological Survey, 1971, Aeromagnetic map of the Winstead Quadrangle, Person and Caswell counties, North Carolina; USGS, Geophys. Invest.

Map no. GP-748, magn. surv. map 1:62,500. 
U.S. Geological Survey, 1971, Aeromagnetic map of the South Boston Quadrangle, Hal ifax County, Virginia, and Person and Granville counties, North Carolina; USGS, Geophys. Invest. Map no. GP-747, magn. surv. map $1: 62,500$.

U.S. Geological Survey, 1971, Aeromagnetic map of the Danville Quadrangle, Pittsylvania County, Virginia, and Caswell County, North Carolina; USGS, Geophys. Invest. Map no. GP-745, magn. surv. map 1:62,500.

U.S. Geological Survey, 1971, Aeromagnetic map of the Roxboro Quadrangle, Person and Granville counties, North Carolina; USGS, Geophys. Invest. Map no. GP-749, magn. surv. map $1: 62,500$.

U.S. Geological Survey, 1973, Surface water supply of the United States, 1968-1970; Part 3, Ohio River basin; Volume 4, Ohio River basin below Wabash River; USGS, Water Supply Pap. no. 2110, 806 p.

Waskom, J.D., 1970, Geology and geophysics of the Lilesville Granite Batholith (late Paleozoic (Pennsylvanian?)), Anson County, North Carolina; Doctoral 1970.

Watts, D. \& H.C. Noltimier, 1974, Paleomagnetic study of diabase dikes in the Inner Piedmont of N. Carolina and Georgia; \{abs\} EOS (Am. Geophys. Union. Trans.), vol. 55, no. 7, p. 675.

White, M.A., et al, 1963, Ordovician age for some rocks of the Carolina Slate Belt in North Carolina; USGS Prof. paper 475-C, p. C107-C109.

White, M.A., \& Almy, C.C., Jr., 1977, Fracture and dike patterns, central Piedmont, Greensboro, North Carol ina; GSA \{abs programs\}, vol. 9, no. 2, p. 195-196.

Worthington, J.E. \& I.T. Kiff, 1970, A suggested voicanigenic origin for certain gold deposits in the slate belt of the North Carolina Piedmont; Econ. Geol., vol. 65 , no. 5, p. 529-537.

Worthington, J.E. \& N.R. Lutz, 1975, Porphyry copper - molybdenum mineralization at the Newell Prospect, Cabarrus County, North Carolina; Southeast. Geol., vol. 17, no. 1, p. 1-14. 
Be11, H., 1969, The regional setting of hydrothermal alteration in part of South Carolina and North Carolina \{abs\}; GSA Abs., Part 7 (Annu\}. Meet.), p. 300.

Be11, H. \& P. Popenoe, 1976, Gravity studies in the Carolina slate Belt near the Haile and Brewer mines, North-central South Carolina.

Be 17, H. \& P. Popenoe, 1973, Some results of geochemical sampling in McCormick County, South Carolina; USGS, Bul1., no. 1376, 22 p.

Brown, H.S. \& N.J. Gilbert, 1977, Geologic history of a fault system in the Charlotte Belt, northern South Carolina \{abs\}; GSA Abst., vol. 9, no. 2, p. 122-123.

Butler, J.R., 1969, Field and petrographic relationships among intrusive rocks of the Carolina Piedmont (abs); GSA Abst., part 4 (Southeast Sect.), p. 12.

Butler, J.R., 1971, Structure of the Charlotte Belt and adjacent belts in the York County, South Carolina; S.C., Div. Geol., Geol. Notes, vol. 15, no. 3-4, p. 49-62.

Butler, J.R., 1965, Guide to the geology of York County, South Carolina; South Carolina State Devel. Board, Div. Geology, Geol. Notes, vol. 9, no. 2 , p. 27-36.

Butler, J.R., 1966, Geology and mineral resources of York County, South Carolina; South Carolina State Devel. Board, Div. Geol. Bul1. 33, $65 \mathrm{p}$.

Butler, J.R. \& P.D. Fullagar, 1977, The Gold Hill Fault Zone in the Carolinas; age of movement and southwestern extension \{abs\}; GSA Abst., vol. 9 , no. 2 , p. 125.

Cazeau, C.J., 1966, Geology of the LaFrance quadrangle, South Carolina; South Carolina State Devel. Board, Div. Geology Map Ser. 10.

Chalcraft, R.G., 1969, Petrography and geophysics of the Rock Hill Gabbro Pluton (Late Paleozoic) (Near Rock Hill, York County), South Carolina; MS Thesis.

Chalcraft, R.G., 1977, A petrographic study of the Ogden Pluton, York and Chester Counties, South Carolina \{abs\}; GSA Abst., vol. 9, no. 2, p. 128. 
Danie1s, D.L., 1974, Geologic interpretation of geophysical maps, central Savannah River area, South Carolina and Georgia; USGS, Geophys. Invest. Map, no. GP-893, geol. map. magn. surv. maps.

Fullagar, P.D., 1969, Whole-rock Rubidium-Strontium ages of the Liberty Hill Pluton, South Carolina and the Salisbury Pluton, North Carolina $\{$ abs $;$; GSA Abst., Part 4 (Southeast Sect.), p. 26.

Griffin, V.S., Jr., 1973, A tectonic interpretation of the Piedmont along the South Carolina-Georgia Border \{abs\}; GSA, Abs., vol. 5, no. 2 , p. 170 .

Griffin, V.S., Jr., 1974, Skylab photograph of the South Carolina Piedmont: a preliminary analysis; South Carolina Div. Geol., Geol. Notes, vol. 18, no. 2 , p. 24-30.

Griffin, V.S., Jr., 1974, Analysis of the Piedmont in northwest South Carolina, GSA Bull., vol. 85, no. 7, p. 1123-1138.

Griffin, V.S., Jr., 1974, Geology of the Walhalla Quadrangle, Oconee County, South Carolina; South Carolina Div. Geol., Map Ser., no. MS- $19,53 \mathrm{p}$.

Hadley, J.B. \& A.E. Nelson, 1970, Caesars Head Quartz Monzonite in the western Carolina Piedmont; USGS Bull., no. 1324-A, p. 23-24.

Hatcher, R.D., Jr., 1974, Regional structural relationships of the Chauga Belt - western mobilized Inner Piedmont of the crystalline southern Appalachians of Northeast Georgia and South Carolina; GSA Abst., vol. 6, no. 7, p. 781.

Hermes, 0.D., 1969, Comparative Petrochemistry of coexistent mafic silicates from the Mecklenburg Gabbro and metagrabbro \{abs\}; GSA Abs, part 4 (Southeast Sect.), p. 35-36.

Horton, J.W., Jr. \& J.R. Butler, 1977, Structural geology of the Kings Mountain and Inner Piedmont belts in the Kings Mountain area, North and South Carolina \{abs\}; GSA Abst., vol. 9, no. 2, p. 148.

Johnson, T.F., 1972, Geology of Columbia North Quadrangle, S.C.; Geol. Surv., geol. map. 1:24,000.

Kese1, R.H., 1972, The Little Mountain Syncline in the South Carolina Piedmont (abs); GSA Abst., vol. 4, no. 2, p. 84.

Kesel, R.H., 1974, Inselbergs on the Piedmont of Virginia, North Carolina and South Carolina; type and characteristics; Southeast Geol., vol. 16, no. 7, p. 1-30.

Levânder, A.R. \& P. Talwani, 1976, Gravity and magnetic mapping in Sharon area, York County, S.C. \{abs\}; GSA Abst., vo1. 8, no. 2, p.219. 
McCauley, J.F., 1961a, Rock analysis in the Carolina Slate Be1t and the Charlotte Belt of Newberry County, South Carolina; Southeastern Geology, vol. 3, no. 1, p. 1-2.

McCauley, J.F., 1961b, Relationship between the Carolina Slate Belt and the Charlotte Belt in Newberry County, South Carolina; South Carolina State Deve1. Board, Div. Geol., Geol. Notes, vol. 5, no. 5, p. 59-66.

McConne11, K.I., 1972, A manganese occurrence in McCormick County, South Carolina; South Carolina Div. Geol., Geol. Notes, vol. 16, no. 1, p. 14-18.

McConne11, K.I. \& V.S. Griffin, Jr., 1973, Petrology of the Anderson Metagabbro; South Carolina Div. Geol., Geol. Notes, vol. 17, no. 3, p. 68-82.

McSween, H.Y., Jr., 1969, Petrological and geochemical studies in the Coronace area; M.S. Thesis.

McSween, H.Y., Jr., 1970, Petrology of Charlotte and Kings Mountain Be1t rocks in northern Greenwood County, South Carolina; South Carolina Div. Geo1., Geol. Notes, vol. 14, no. 3, p. 57-84.

Marine, I.W., 1975, Water level fluctuations due to earth tides in a well pumping from slightly fractured crystalline rock; Water Resour. Res., vol. 11, no. 1, p. 165-173.

Medlin, J.H., 1968, Comparative petrology of two igneous complexes in the South Carolina Piedmont; Doctoral. Diss., The Pennsylvania State Univ.

Medlin, J.H., et. al., 1972, Petrology of the mafic igneous complexes in the southeastern U.S. Piedmont; Lt., the Buffalo mafic igneous complex, Union County, South Carolina; Southeast Geol., vol. 14, no. 2 , p. $73-106$.

Neathery, T.L. (Chairman), 1973, Symposium: Geology of the Blue RidgeAshland-Wedowee Belt in the Piedmont; Am. J. Sci., vol. 273, no. 8, p. $641-756$.

Overstreet, W.C., 1970, The Piedmont: The Piedmont in South Carolina; Intersci. Publ., New York.

Overstreet, W.C. \& H. Bell III, 1965a, The crystalline rocks of South Carolina; U.S. Geol. Sur. Bu11., no. 1183,126 p.

Overstreet, W.C. \& H. Bell III, 1965b, Geologic map of the crystalline rocks of South Carolina; USGS Misc. Geo7. Inv. Map I-413, scale $1: 250,000$.

Oyerstreet, W.C., et. al., 1963, Geology of the Shelby Quadrangle North Carolina; USGS Misc. Geol. Inv. Map I-384. 
Paradeses, W., et. al., 1966, The geology of the Blythewood Quadrangle; South Carolina State Devel. Board, Div. of Geol. Map Ser. 13.

Potter, D.B., 1954, High alumina metamorphic rocks of the Kings Mountain District, North Carolina and South Carolina; USGS open-file report $204 \mathrm{p}$.

Privett, D.R., 1974, Laumontization in Kings Mountain Belt rocks Cherokee County, South Carolina, South Carolina, Div. Geol. Notes, vol. 18, no. 2, p. 3]-35.

Privett, D.R., 1973, Laumontization near the northern margin of the Liberty Hill Batholith, southern Chester County, South Carolina; South Carolina Div. Geol., Geol. Notes, vol. 17, no. 3, p. 49-54.

Privett, D.R., 1977, Widespread zeolitization in the central Charlotte Belt, north central York County, South Carolina \{abs\}; GSA Abs., vol. 9 , no. 2, p. 176.

Ragland, P.C. \& J.R. Butler, 1969, Differentiation trends in the intrusive rocks of the Carolina Piedmont (abs); GSA, Abst., Part 4 (Southeast Sect.), p. 66.

Randazzo, A.F., 1969, Petrology and stratigraphy of the Carolina Slate Belt, Union County, North Carolina (abs); Diss. Abst., vol. 29, no. 7, p. 2496 B.

Ridgeway, D.C., et. a1., 1966, Geology of the Blaney Quadrangle, South Carolina; South Carolina State Deve1. Board Div. of Geo1. Map Service 11 .

Ritchie, A.W. \& W.C. Fallaw, Post-orogenic dike swarms, and structural style on the South Carolina Slate Belt \{abs\}; GSA Abs., vol. 8, no. 6 , p. 1072 .

Scheffler, P., 1975, Recent Earthquakes in the South Carolina Piedmont (abs); GSA Abs., vol. 7, no. 4, p. 530-531.

Secor, D.T., Jr. \& A.W. Snoke, 1977, Stratigraphic and structural relationships, Carolina Slate Belt centra\} South Carolina \{abs\}; GSA Abstr., vol. 9, no. 2, p. 183.

Shiver, R.S., 1974, The geology of the Heath Springs Quadrangle, Heath Springs, South Carolina; MS Thesis, North Carolina State.

Siple, G.E., 1946, Groundwater Investigations in South Carolina; Res. and Planning \& Dev. Board, Bull. no. 15.

Snipes, D.S., 1969, Metasomatism and Granitization at Master's Kiln, Laurens County, South Carolina; \{abs\}, GSA Abstr., Part 4 (Southeast Sect.), p. 77. 
Snoke, A.W., et. al., 1977, Batesburg-Edgefield cataclastic zone: a fundamental tectonic boundary in the South Carolina Piedmont; GSA Abstr., vol. 9, no. 2, p. 185-186.

Spence, W.H., et. a1., 1972, Potash-silica ratios in some andesites of the Carolina Slate Be1t; Elisha Mitchell Sci. Soc. J., vol. 88, no. 4, p. 197-198.

Spence, W.H., et. a1., 1975, A model for the origin of the pyrophyllite deposits in the Carolina Slate Belt $\{a b s\}$; GSA Abst., vol. 7, no. 4 , p. 536-537.

Tewhey, J.D., 1973, The transition between metamorphic belts on the southeast edge of the Carolina Slate Belt, South Carolina $\{a b s\}$; GSA Abst., vol. 5, no. 5, p. 443.

Wagener, H.D., 1974, The York-Chester gabbro-metagabbro-amphibolite complex, South Carolina Div. Geol., Geol. Notes, vol. 18, no. 1, p. 1-3.

Wagener, H.D., 1977, Zeolites as indications of time of latest movement on Piedmont faults; the Virgil $C$. Summer Nuclear Station $\{a b s\}$; GSA Abs., vol. 9, no. 2, p. 192-793.

Wagener, H.D. \& D.E. Howe11, 1973, Granitic plutons of the central and eastern Piedmont of South Carolina; Field trip guidebook; Pageland, South Carolina; South Carolina State Dev. Bd. Div. Geol., 25 p.

Webster, D.S., et. al., 1970, Two-well tracer test on fractured crystalline rock; USGS, water-supply paper no 1544-I, 22 p.

Weisenfluh, G.A., 1977, An epizonal trondhjemite-quartz keratophyre igneous complex; island arc volcanism within the South Carolina Piedmont $\{a b s\}$; GSA Abs., vol. 9, no. 2, p. 194-195.

Wilson, T.V., 1973, Prediction of baseflow for a Piedmont Watershed \{Abs\}, Diss Abs. Int., vol. 34, no. 5, p. 2140B-2141B. 


\section{BIBLIOGRAPHY - Georgia}

Anrya, M., 1944, Morphometric studies of monadnocks on the Georgia Piedmont; MA Thesis, University of Georgia

Austin, R.S., 1965, The Geology of southeast Elbert County, Georgia; Unpublished MA Thesis, University of Georgia.

Austin, R.S., 1966, Mafic intrusive rocks of southeast Elbert County, Georgia \{abs\}; in Abstracts for 1961, GSA Spec. Paper 101, p. 349350 .

Austin, R.S., 1969, A stratigraphic section in the metamorphic Little River Series in east central (Piedmont) Georgia \{abs\}; Georgia Acad. Sci. Bul1., v. 27, p. 88.

Bentley, R.D. \& T.L. Neathery, 1970, Geology of the Brevard Fault Zone and related rocks of the inner Piedmont of Alabama (and westcentral Georgia); Alabama Geol. Soc. Guidebook Ann. Field Trip:, $\mathrm{xi}, 119 \mathrm{p}$.

Burchfield, B.C., \& J.L. Livingston, 1968, Brevard Zone compared to Alpine Root Zones; Am. Jour. Sci., v. 265, p. 241-256.

Carpenter, R.H., 1977, A Gravity Survey of the south-central Georgia Piedmont; Georgia Geo. Surv., inf. circ., 42, 6 p.

Christensen, F.B., 1967, Earthquake frequency in South Carolina and Georgia (abs); South Carolina Acad. Sci. Bull., v. 29, p. 49.

Coleman, S.L., et. a1., 1973, Petrology and Geochemistry of the Austell Gneiss in the western Georgia Piedmont \{abs\}; GSA abstract, vol. 5, no. 5, p. 388 .

Crawford, T.J., 1957, Geology of part of Indian Mountain, Polk County, Georgia, and Cherokee County, Alabama; Georgia Min. Newsletter, v.x, no. 2 , p. 39-51.

Crawford, T.J., \& J.H. Medlin, 1970, Stratigraphic and structural features between Cartersville and Brevard Fault Zones; Georgia Geol. Soc. Ann. Field Trip 5: Atlanta, Georgia Dept. Mines, Mining and Geology (Guidebook 9), 37 p.

Crawford, T.J., 1971, The Georgia Piedmont west of Atlanta; stratigraphic and structural features \{abs\}; GSA, abstra., vol. 3, no. 5, p. 306.

Crawford, T.J., \& J.H. Medlin, 1973, The western Georgia Piedmont between the Cartersville and Brevard Fault Zones; Am. J. Sci., vol. 273, no. 8, p. 712-722. 
Cressler, C.W., 1970, Geology and groundwater resources of Floyd and Polk Counties, Georgia; Georgia Geol. Survey Inf. Circ. 39, 95 p.

Crickman, G.W., 1952, Geology of the crystalline rocks of Georgia; Georgia Geol. Surv., Bu11. 58.

Dallmeyer, R.D., 1977, 40 AR/39 AR incremental - release ages of hornblende and biotite across the Georgia Inner Piedmont: their bearing on late Paleozoic - early Mesozoic tectonothermal history; GSA Abs. Prog., vol. 9, no. 2, p. 131.

Daniels, D.L., 1974, Geologic interpretation of geophysical maps, central Savannah River area, South Carolina and Georgia; USGS, Geophy. Invest. Map No. GP-893.

Dorman, L.M., 1972, Sejsmic crustal anisotropy in northern Georgia; Seismo 1. Soc. Am., Bu11., vol. 62, no. 1, p. 39-45.

Fairley, W.M. \& R.D. Bentley, 1965, The Murphy Syncline in the Tate Quadrangle (Cherokee, Dawson, Forsyth, and Pickens Counties) Georgia; Georgia Geol. Surv. Bul1. 75, 71 p.

Fairley, 1966, Cartersville Thrust (Fault), Georgia and stratigraphic correlations between the Piedmont and the Appalachian Valley \{abs\}; in Abstracts for 1965, GSA Spec. Paper 87, p. 247.

Fairley, 1966, The Cartersville Thrust (Fault) at Cartersville (Bartow County) Georgia in The Cartersville Fault problem - Georgia Geol. Soc. Ann. Field Trip, no. 1: Georgia Geo. Sur. Guidebook ser. no. 4 , p. 28-33.

Fairley, 1971, The Piedmont in Georgia; Discussion \{Abs\}, GSA Abs., vol. 3 , no. 5 , p. 309-310.

Fairley, 1973, Correlations of Stratigraphic Belts of the Northwest Georgia Piedmont and Blue Ridge; Am. Jour. Sci., vol. 273, no. 8, p. 686-697.

Fullagar, P.D., 1970, Age and origin of plutonic intrusives in the Piedmont of the southern Appalachian (Hancock County) (abs);

GSA abst. with Programs, v. 2, p. 556-557.

Fullagar, P.D. \& J.R. Butler, 1974, Strontium isotopic and chemical study of granitic rocks from the Piedmont near Sparta, Georgia $\{$ abs\}; GSA Abs, vol. 6, no. 4, p. 357. Grant, W.H., 1958, The Geology of Hart County, Georgia; Georgia Geo.
Surv. Bu17. 67.

Grant, W.H., 1968, Interpretation of Pine Mountain, southwestern Pied mont of Georgia \{abs\} in Abs. for 1967: GSA Spec. Paper 115,
p. 476 . 
Grant, W.H., 1968, Weathering, streams and structure in the central Piedmont of Georgia \{abs\}; Georgia Acad. Sci. Bul1., v. 26, p. 68 .

Grant, W.H., 1969, Apatite weathering in the Panola Granite (De Kaib and Henry Counties) \{abs\}; Georgia Acad. Sci. But1., v. 26, p. 90-91.

Grant, W.H., 1969, Movements in the Towaliga Fault Zone, Pike and Lamar Counties, Georgia \{abs\}, in Abstracts for 1968, GSA Spec. Paper 121 , p. 440-441.

Griffin, V.S., Jr., 1973, A Tectonic interpretation of the Piedmont along the South Carolina - Georgia Border \{abs\}; GSA Abs., vol. 5, no. 2, p. 170 .

Guinn, S.A., 1973, Molybdenite, Siloam granite quarry, Greene County Georgia Acad. Sci., Bul1., vol. 31, no. 2, p. 81 .

Guinn, S.A., 1974, Rapakivi texture, Siloam Granite quarry, Greene County, Georgia; Ga. Acad. Sci., Bul1., vol. 32, no. 1-2, p. 15.

Hatcher, R.D., Jr., 1974, Regional structural relationships of the Chauga Belt - western mobilized Inner Piedmont of the crystalline southern Appalachians of northeastern Georgia and South Carolina; Geo1. Soc. Am., Abst. Prog., vol. 6, no. 1, p. 781.

Hermann, L.A., 1954, Geology of the Stone Mountain - Lithonia District; Georgia, Georgia Geol. Surv. Bul1., 61.

Higgins, M.W., 1965, The geology of part of Sandy Springs Quadrangle (Cobb and Fulton Counties) Georgia; MS Thesis, Ga. State Univ., 147 p.

Higgins, M.W., 1966, The geology of the Brevard Lineament near Atlanta, Georgia; Georgia Geol. Surv. Bul1. 77, vi, 49 p.

Higgins, M.W., 1968, Geologic Map of the Brevard Fault Zone near Atlanta, Georgia USGS misce1. Geo1. Invest. Map I-511.

Higgins, M.W., et. a T., 1970, New aeroradio-activity map of the Georgia Nuclear Laboratory area \{abs\}; GSA Abs. with Programs, vo?.2, p. 216.

Hinton, J.L. \& C.T. Williams, 1975, Petrology and Chemistry of calcsilicate rocks in Fulton and Coweta Counties, Georgia; Georgia Acad. Sci., Bull., vol. 33, no. 2, p. 78.

Holland, W.A., Jr. \& S. Schamel, 1973, Structural relations between the Uchee and the Goat Rock-Bartletts Ferry Mylonite Zone, AlabamaGeorgia Piedmont \{abs\}; GSA Abs., vol. 5, no. 5, p. 405. 
Howard, J.H. III, 1971, Hardpans on crystalline rocks of Georgia Piedmont \{abs\}; GSA Abs, vol. 3, no. 5, p. 322-323.

Humphrey, R.C., 1970, The geology of the crystalline rocks of Greene and Hancock Counties, Georgia; MS Thesis, Univ. of Georgia, $57 \mathrm{p}$.

Humphrey, R.C. \& D. Radcliffe, 1970, The petrology of the Siloam Granite, Greene County, Georgia \{abs\}; GSA Abs, vol. 2, p, 220.

Hurst, V.J., 1970, The Piedmont: The Piedmont in Georgia; in studies of Appalachian Geology, Central and Southern Piedmont, p. 383-396.

Jones, D.D., Jr., 1970, Petrofabric and movement study of faults in Newton and Walton Counties, Georgia; MS Thesis.

Jones, D.D., Ir. \& R. L. Walker, 1973, The rubidium strontium wholerock age of the Siloam Granite, Georgia: a Permian intrusive in the southern Appalachians; Abst. Geochronology Isot. Geol., no. 7 , 1 p.

Jones D.D., Jr. \& R.L. Walker, 1973, Rb-Sr Whole-rock age of the Siloam Granite, Georgia; a Permiam Intrusive in the southern Appalachians; GSA Bul1., vol. 84, no. 11, p. 3653-3658.

Julian, L.C., 1972, Petrology of an orbicular granite in the Elberton Batholith, Elbert County, Georgia; MS Thesis.

Julian, L.C., 1972, An orbicular adamellite, Elbert County, Georgia, Elisha Mitchell Sci. Soc. J., vol. 88, no. 4, p. 196-197.

Lawton, D.E., 1969, Geology of the Hard Labor Creek area, in west-central Morgan County, Georgia; MS Thesis, Univ. of Georgia, 51 p.

LeGrand, H.E., 1968, Quantified hydrologeology of crystalline rocks in the southeast states \{abs\} in Abstracts for 1966: GSA Spec. Paper 101, p. 366 .

LeGrand, H.E., 1969, Exploration of subsurface conditions (for groundwater) in the Piedmont and Blue Ridge provinces $\{a b s\}$; in Abs. for 1968: GSA Spec Paper 121, p. 451-452.

Libby, S.C., 1971, The petrology of the igneous rocks of Putnam County, Georgia; MS Thesis, Univ. of Ga.

Long, L.T., 1971, Local magnitudes and recent earthquake activity near the Georgia-South Carolina Border $\{a b s\}$; Earthquake Notes, vol. 42 , no $3-4$, p. 17.

Long, L.T., 1974, Bouquer gravity anomalies of Georgia; Georgia Geol. Surv. But1., no. 87 , p. 141-166. 
McCollum, M.J., 1966, Groundwater resources and geology of Rockdale County, Georgia; Georgia Geo. Surv. Inf. Circl. 33, 17 p.

McLenmore, W.H., 1965, The geology of Pollard's Corner area, Columbia County, Georgia; MS Thesis, Univ. of Georgia, 49 p.

Man1ey, F.H. \& T.L. Sewe11, 1973, Vermiculite and hydrobiotite in an igneous complex, Elbert County, Georgia; Georgia Acad. Sci., Bu11., vol. 31 , no. 2, p. 84 .

Matthew, V. III, 1969, The Gladesville Norite and its relationship to similar mafic plutons in the Georgia Piedmont \{abs\}; Part 4 (Southeast Sect.) p. 50 .

Medlin, J.H., and V.J. Hurst, 1967, Geology and mineral resources of The Bethesda Church area, Greene County, Georgia; Georgia Minera 1 Newsletter, v. IX, p. 46-61.

Medlin, J.H., and V.J. Hurst, 1965, Subsurface "basement" rocks of Georgia; Georgia Dept. of Mines, Mining and Geology, Bul1. 76, $56 \mathrm{p}$.

Murphy, J.B., 1972, Reconnaissance geology of an area northwest of the Brevard Fault Zone, Forsyth County, Georgia: A progress report (abs); GSA Abst. vol. 4, no. 2, p. 96.

Myers, C.W., 1969, Geology of the Presley's Mill area, Northwest Putnam County; MA Thesis, Univ. of Georgia.

Neathery, T.L., 1973, Symposium: Geology of the Blue Ridge-AshlandWedowee Belt in the Piedmont; Am. J. Sci., vol. 273, no. 8, p. $641-756$.

0'Connor, B.J., 1974, A Brevard Quartzite-schist unit extending into the Inner Piedmont of Georgia \{abs\}; GSA Abs., vol. 6, no. 4, p. 383384.

0'Connor, B.J., et. al., 1974, Recently discussed faults in the central Savannah River area; Georgia Acad. Sci., Bul1. vol. 32, no. 1-2, p. 15.

Parks, W.S., Jr., 1974, X-ray Petrofabric analysis of cataclastic quartzites from the Brevard Zone in North Georgia \{abs\}; GSA Abs, vol. 6, no. 4, p. 385 .

Person, W.J., 1977, Earthquakes, December, 1976; Earthquake Inf. Bu11., vol. 9 , no. 3 , p. 28-29.

Pickering, S.M., Jr., et. al., 1976, Fold-related fracture patterns in crystalline rocks near Atlanta, Georgia, and their relation to groundwater availability; GSA Abs., vol. 8, no. 2, p. 245-246. 
Power, W.R. \& J.T. Forrest, 1973, Stratigraphy and Paleogeography in the Murphy Marble Belt; Am. J. Sci., vol. 273, no. 8, p. 698-711.

Prather, P. \& D. Radcliffe, 1970, Petrology of the norites of Monroe County, Georgia (abs); GSA Abs, vol. 2, no. 3, p. 238.

Ramspott, L.D., 1965, The Danburg Granite \{abs\}; Georgia Acad. Sci. Bul1, vol. 23, p. 70-71.

Ramspott, L.D., 1965, Earliest effects of weathering on Elberton Granite; Georgia Acad. Sci. Bul1., v. 23, p. 34-35.

Ramspott, L.D., 1966, Tectonic origin in color on pink granites of Elberton District Georgia \{abs\}; Georgia Acad. Sci. Bull., v. 24, p. 75-76.

Ramspott, L.D. \& E.L. Plunkett, Jr., 1967, Fe/(Fe $+\mathrm{Mg})$ ratio in biotite from Georgia granite rocks; Am. Mineralogist, v. 52, p. 902-908.

Ramspott, L.D., 1967, Zeolites in the Georgia Piedmont; Georgia Acad. Sci. Bult., vol. 25, p. 18-25.

Ramspott, L.D., 1968, Nature of the Elberton Batholith \{abs\}; in Abstracts for 1966: GSA Spec. Paper 101, p. 372.

Sandrock, G.S. \& H.M. Penley, 1974, Geologic Map of the Pine Mountain Series and adjacent areas in the southwest Georgia Piedmont abs ; GSA Abs, vol. 6, no. 4, p. 395.

Schame1, S., et. a1., 1976, Structure of the Pine Mountain Belt and adjacent terranes, west-central Georgia Piedmont; GSA Abs. Programs, vol. 8, no. 2, p. 260-261.

Sewe11, T.L., 1973, Migmatite in Elbert County, Georgia; Ga. Acad. Sci. Bu11., vol. 31 , no. 2, p. 81 .

Sever, C.W., 1964, Geology of groundwater resources of crystalline rocks, Dawson County, Georgia; Georgia Geologic Surv. Inf. Circ. 30.

Siple, G.E., 1967, Geology and groundwater of the Savannah River Plant and vicinity, South Carolina USGS Water Supply Paper 1841.

Smith, J.W., et. al., 1969, Isotopic dating and metamorphic isograds of the crystalline rocks of Georgia, in Precambrian-Paleozoic Appalachian problems: Georgia Geol. Surv. BuT1. 80, p. 121-139.

Smith, J.W. \& M.A. Green, 1969, Large granitic exposures in Georgia \{abs\}; Georgia Acad. Sci. Bul1. v. 27, p. 93.

Smith, J.W. \& M.A. Green, Mineral resource map of Georgia; Atlanta, Georgia Dept. Mines, Mining and Geology. 
Stahe1i, A.C., 1973, Marine terracing on the Georgia Piedmont; Georgia Acad. Sci., Butl. vol. 31 , no. 2, p. 80.

Staheli, A.C., 1974, Topographic indications of marine terracing on the Georgia Piedmont \{abs\}; GSA Abs., vol. 6, no. 4, p. 400.

Staheli, A.C., 1974, Topographic lineations on the Georgia Piedmont and their possible relationship to the Brevard Zone lineament $\{a b s\}$; GSA Abs., vol. 6, no. 4, p. 400-401.

Staheli, A.C., 1976, Topographic expression of superimposed drainage on the Georgia Piedmont; GSA Bul1., vol. 87, no. 3, p. 450-452.

Staheli, A.C., 1975, Topographic indications of the evolution of superimposed drainage on the Georgia Piedmont \{abs\}; GSA Abs., vol. 7, no. 4 , p. 557-538.

Staheli, 1976, Origin of swamps on the Georgia Piedmont; GSA Abs. Programs, vol. 8, no. 2, p. 274-275.

Staheli, 1977, Geologic significance of Riverine swamp distribution on the Georgia Piedmont; GSA Abs. Programs, vo1. 9, no. 2, p. 186.

Stewart, J.W., 1958, Earthquake history of Georgia; Georgia minera $i$ Newsletter, $v$. XI, no. 1-4, p. 127-128.

Stewart, J.W., et. a1., 1964, Georgia and hydrologic investigation at the site of the Georgia Nuclear Laboratory, Dawson County, Georgia; USGS, Bu11., 1133-F, 90 p.

U.S. Geological Survey, 1977, Aeromagnetic map of parts of Rome, Atlanta and Phoenix City; USGS Open-File Rep., no. 77-345, magi. surv. map.

Watts, D. \& H.C. Noltimier, 1974, Paleomagnetic study of diabase dikes in the Inner Piedmont of N. Carolina and Georgia \{abs\}; EOS (Am. Geophys. Union Trans.), vol. 55, no. 7, p. 675.

Whitney, J.A., et. al., 1975, Feldspar thermal history for three postmetamorphic granites from the Georgia Piedmont \{abs\}; GSA Abs., vol. 7 , no. 4, p. 549.

Whitney, J.A. \& J.C. Stormer, Jr., 1977, Two-feldspar geothermometry, geobarometry in mesozonal granitic intrusions; three examples from the Piedmont of Georgia; Contrib. Minera1: Petrol-Beitr. Mineral, Petrol., vol. 63, no. 1, p. 51-64. 


\section{BIBLIOGRAPHY - Miscellaneous}

Dietrich, R.V., 1964, Igneous activity in the Southern Appalachians; Lowry, W.D., ed., Tectonics of the Southern Appalachians, Virginia Polytech, Inst. Dept. Geo1. Sci. Memo. 1, p. 47-61.

Fisher, G.W., \& M.W. Higgins, 1972, Northern Piedmont: stratigraphy, structure, evolution; Geotimes, vol. 17, no. 11, p. 19-20.

Fisher, G.W., 1976, The geologic evolution of the northeastern Piedmont of the Appalachians; GSA \{abs programs\}, vol. 8, no. 2, p. 172-173.

Glover, L., III, 1974, Speculations on the relation between eastern and western Piedmont volcanism; GSA \{abs\} vol. 6, no. 7, p. 757.

Hatcher, R.D., et al, 1977, Eastern Piedmont fault system, some speculations on its extent; GSA \{abs programs\}, vol. 9 no. 2, p. 145-146.

Higgins, M.W., et al, 1977, U-Pb zircon dates from the central Appalachian Piedmont: a possible case of inherited radiogenic lead; GSA Bul1., vol. 88, no. 1, p. 125-132.

Khoury, S.G., et a1, 1976, Expression of 1ithologies and structures on aeromagnetic and gravity maps of the Piedmont in the central Appalachians; GSA \{abs programs\} vol. 8, no. 2, p. 209-210.

King, P.B., 1949, The base of the Cambrian in the southern Appalachians; Am. J. Sci., vol. 247, p. 513-530 \& p. 622-645.

Odom, A.L., et al, 1976, Distribution and age of Precambrian basement in the southern Appalachians; GSA \{abs. programs\}, vol. 8, no. 2, p. 238 .

Russel1, G.S., 1976, Rb-Sr evidence from cataclastic rocks for Devonian faulting in the southern Appalachians; GSA \{abs programs\} vol. 8, no. 6 , p. 1081 .

Sinha, A.K., 1976, Timing of metamorphic and igneous events in the central Piedmont and Blue Ridge; GSA \{abs programs\} vol. 8, no. 2, p. 267.

Stonebraker, J.D., \& C.T. Harper, 1973, Potassium - argon geochronology of the Brevard Zone GSA \{abs\}, vol. 5, no. 5, p. 439 .

Tanner, W.F., 1976, Geothermal exploration from deep-well data; Am. Assoc. Pet. Geol. Bu11., vol. 60, no. 9, p. 1616-1617.

Todd, W.J., 1977, Urban and regional land use change detected by using Landsat data; J. Res. USGS, vol. 5, no. 5, p. 529-534. 


\section{Miscellaneous}

2

Trimble, S.W., 1973, A geographic analysis of erosive land use on the southern Piedmont, 1700-1970; Georgia Doctora].

U.S. Geological Survey, 1975, Groundwater levels in the United States, 1969-73, Southeastern states; U.S.G.S. Water Supply Pap. no. 2171 , $250 \mathrm{p}$.

Williams, H., 1976, Tectonic - stratigraphic subdivisions of the Appalachian Orogen; GSA \{abs programs\}, vol. 8, no. 2, p. 300 . 
APPENDICES

, 


\section{APPENDIX A}

PHYSICAL AND MECHANICAL PROPERTIES OF ROCK 


\author{
APPENDIX A \\ PHYSICAL AND MECHANICAL \\ PROPERTIES OF ROCK
}

The qualitative descriptions of the various physical and mechanical properties of rock listed in Table 3 are defined quantitatively in this Appendix. The numerical values given are taken from recognized engineering references but, in the context of this report, are intended to indicate orders of magnitude and provide guidelines for further studies. 
Description

Very High

High

Medium

Low

Very Low
Uniaxial Compressive Strength

$\underline{\mathrm{MPa}}$ $1 \mathrm{bf} / \mathrm{in}^{2}$

$>220$ $>32,000$

$110-220$

$55-110$

$16,000-32,000$

$8,000-16,000$

$28-55$

$4,000-8,000$

$>28$

$>4,000$

MODULUS OF ELASTICITY*

On the Basis of Modulus Ratio $\left(E_{t} / \sigma_{a}(u l t)\right)$

Description

High Modulus Ratió-

Average (Medium) Ratio

Low Modulus Ratio
Modulus Ratio ${ }^{\star \star}$

$>500$

$200-500$

$>200$
-3

"

y

*After: Deere, R.U. \& R.P. Miller, 1966, Engineering classification and index properties for intact rock, Tech. Rept. No. AFWL-TR-65-116, Air Force Weapons Lab., Kirtland Air Force Base, New Mexico.

**Modulus Ratio $=E_{t} / \sigma_{a}(u l t) \quad$ where $E t=$ tangent modulus at $50 \%$ ultimate strength

$$
\left.\sigma_{a}(u\} t\right)=\begin{aligned}
& u l t i m a t e \\
& \text { compressive strength }
\end{aligned}
$$




\section{Rock Density}

The density of a substance is the mass per unit volume and reflects the nature of the atoms in the structure and manner in which they are packed together. The more dense a rock, the more mass per unit volume is provided in offering shielding against radioactivity. In general, igneous and metamorphic rocks are more dense than sedimentary rocks. Below is a list of some of the more common rocks and their approximate densities:

Rock

Gabbro

Basalt

Diorite

Anorthosite

Granite

Rhyolite
Specific Gravity

2.97

2.87

2.87

2.75

2.66

2.49 
Rock Quality

Rock quality is here defined by Rock Quality Designation (RQD) and is based on a modified core recovery procedure which, in turn, is based indirectly on the number of fractures and the amount of softening or alteration in the rock mass as observed in the rock cores from a drill hole. RQD is obtained by summing up the total length of sound rock core recovered from a single core run (usually $150 \mathrm{~cm}$ (60 ins)), and expressing that sum as a percentage of the total core run. Sound core is defined as those pieces of core which are $10 \mathrm{~cm}$ (4 ins) or more in length and which are hard and sound.

$\underline{\mathrm{RQD}}$

0-25

25-50

50-75

$75-90$

$90-100$
Description of Rock Quality

Very Poor

Poor

Fair

Good

Excellent

*After: Deere, 1966 
Rock Material Strength

Description

Very Strong

Strong

Moderately Strong

Moderately Weak

Very Weak Rock or Hard Soi 1
Field Estimation of Hardness

Very hard rock - more than one blow of geological hammer required to break specimen.

Hard rock - hand-held specimen can be broken with single blow of geological hammer.

Soft rock - $5 \mathrm{~mm}\left(\frac{1}{4} "\right)$ indentations with sharp end of pick

Too hard to cut by hand into a triaxial specimen.

Brittle or tough, may be broken in the hand with difficulty.

*After: Report by the Geological Society Engineering Group, Working Party; the Description of Rock Masses for Engineering Purposes: Quat. J. Engng. Geol., 1977, v. 10, No. 4, p. 355-388. 
A-6

Joint Spacing*

Descriptive Term Spacing of Joints

Very Close

$<5 \mathrm{~cm}$

$<2$ ins

Close

$5-30 \mathrm{~cm}$

$2-12$ ins

Moderately CTose

$30-100 \mathrm{~cm}$

$1-3$ feet

Wide

$1-3 m$

$3-10$ feet

Very Wide

$>3 m$

$>10$ feet

*After: Deere, 1966

ir

r)

at 